\author{
Clara Carvalho de Lemos
}

\title{
AVALIAÇÃO AMBIENTAL ESTRATÉGICA COMO INSTRUMENTO DE PLANEJAMENTO DO TURISMO
}

\begin{abstract}
Dissertação apresentada à Escola de Engenharia de São Carlos, da Universidade de São Paulo, como requisito para a obtenção do Título de Mestre em Ciências da Engenharia Ambiental.
\end{abstract}

Orientador: Prof. Dr. Marcelo Pereira de Souza 
Aos meus pais, responsáveis por tudo, incentivadores e fontes de inspiração. 


\section{AGRADECIMENTOS}

Ao Marcelo, pela oportunidade que me foi dada, pela amizade, orientação ao trabalho, incentivo e por ter contribuído e servido de exemplo para meu amadurecimento pessoal e profissional.

À Isabel, pelo tempo dedicado às leituras e análise crítica do trabalho, pelas sugestões e co-orientação.

Ao Prof. Evaldo, pelo convite e pela oportunidade que me foi dada em participar da equipe de pesquisa do Projeto Mogi-Guaçu em Bueno Brandão, viabilizando minhas viagens para estudo de campo.

Aos meus pais, irmãos (Rafa e Filipe) e todos familiares, pela presença constante, pelo apoio e carinho.

Aos amigos de perto Dani, Vivi, Paty, Érica e Cremis, pelos momentos de convivência tão especiais, e a todos aqueles que fizeram da minha estadia em São Carlos uma experiência mais alegre, agradável, enriquecedora e internacional!

Aos amigos de longe, mas sempre disponíveis, Rachel, Marina, Wladia, Michelle, Sônia, Clarissa, Cristina e Mari.

Ao Bruno, pela companhia, amor e paciência.

Ao Yuri, pela amizade, auxílio no trabalho de campo, observações e sugestões.

Ao Programa Petrobrás Ambiental, pelo patrocínio das viagens a campo e ao CNPq, pelo suporte financeiro.

Aos funcionários e professores do CRHEA.

À Elena, pela revisão das referências bibliográficas.

Aos amigos Lu, Juninho, Val, Marcelo, Newton, Marinho, Cavini e todos que conheci e com quem convivi em Bueno Brandão, pelo apoio, amizade, incentivo e enorme receptividade. 
Desconfiai do mais trivial, na aparência singelo.

E examinai, sobretudo, o que parece habitual.

Suplicamos expressamente:

não aceiteis o que é de hábito como coisa natural, pois em tempo de desordem sangrenta, de confusão organizada, de arbitrariedade consciente, de humanidade desumanizada, nada deve parecer natural nada deve parecer impossível de mudar.

Bertolt Brecht

"Somos condenados a ser espectadores? Podemos alterar o desenrolar dos eventos? Podemos sofrer crises de compaixão sem apresentar sintomas de uma crise de consumo?" 


\section{RESUMO}

LEMOS, C. C. (2007). Avaliação ambiental estratégica como instrumento de planejamento do turismo. Dissertação (Mestrado) - Escola de Engenharia de São Carlos, Universidade de São Paulo, São Carlos, 2007.

Tendo em vista a emergência do turismo como atividade de significativo impacto econômico e, conseqüentemente, de potencial impacto negativo ao meio ambiente, o presente trabalho avalia as perspectivas de aplicação da avaliação ambiental estratégica como instrumento de consideração e ponderação das questões ambientais na tomada de decisão e planejamento do turismo no Brasil. Por meio de revisão bibliográfica e de análise da prática internacional, discute a relação turismo e meio ambiente, os instrumentos utilizados para a gestão ambiental da atividade e as experiências de aplicação da avaliação ambiental estratégica em turismo. Além disso, o trabalho traz um estudo de caso no Município brasileiro de Bueno Brandão, no Estado de Minas Gerais, com o intuito de apresentar o cenário político e institucional local e avaliar as condições e os desafios para uma possível inserção da avaliação ambiental estratégica no plano municipal de desenvolvimento turístico. Conclui-se que, apesar de já existir certo consenso no que diz respeito a princípios e boas práticas de $\mathrm{AAE}$, as experiências internacionais em políticas, planos e programas de turismo ainda apresentam uma série de imprecisões em termos de metodologia, formas de participação e abordagens. Entende-se que, no Brasil, ainda existe uma série de desafios, metodológicos e políticos, para garantir a inserção do meio ambiente na tomada de decisão de forma participativa. Esse fato ficou claro com as questões identificadas no estudo de caso, especialmente aquelas relacionadas aos mecanismos de participação da sociedade, capacitação do corpo técnico, ações de planejamento integradas e articuladas, e produção, sistematização, democratização e monitoramento de informações ambientais, de forma a orientar o planejamento e a tomada de decisão.

Palavras-Chave: Avaliação ambiental estratégica, turismo, políticas públicas. 


\begin{abstract}
LEMOS, C. C. (2007). Strategic environmental assessment as a tool for tourism planning. M.Sc. Dissertation - Escola de Engenharia de São Carlos, Universidade de São Paulo, São Carlos, 2007.

Considering the raising of the tourism sector as an activity of significant economic impact and, consequently, potential negative environmental impacts, the present work evaluates the perspectives for application of strategic environmental assessment as a tool which can integrate environmental issues into tourism planning in Brazil. Using bibliographical research and analysis of the international practice, this work discusses the relationship between tourism and environment, the environmental management tools used and the practical experiences of strategic environmental assessment in the tourism sector. Beyond that, the work presents a case study in Bueno Brandão, a Brazilian town located in the State of Minas Gerais, in which it discusses the political and institutional setting and evaluates the conditions and challenges for a possible insertion of the strategic environmental assessment in the local tourism development plan. Although it already exists certain consensus in strategic environmental assessment principles and good practices, the international experiences in SEA for tourism planning still presents some imprecisions in methodology, public participation and approaches. It is clear that in Brazil there are still challenges in methodological and political approaches to guarantee the insertion of environmental concerns in the decision making and public participation contexts. This fact was confirmed by the issues identified in the case study, mainly, failures related to the mechanisms of public participation, the qualification of the technical staff, integration of planning actions, and the production, systematization, democratization and monitoring of environmental information, in a way to guide the decision making and local planning.
\end{abstract}

Keywords: Strategic environmental assessment, tourism, public policies. 


\section{LISTA DE FIGURAS}

Figura 1. Avaliação de alternativas nos diferentes níveis de tomada de decisão. .30

Figura 2. Um típico modelo de seqüência de níveis hierárquicos de políticas .32

Figura 3. As duas abordagens de AAE .42

Figura 4. Um modelo conceitual simplificado de constituição de uma política sem (A) e com (B) a Avaliação Ambiental Estratégica. .45

Figura 5. Etapas do processo de AAE .64

Figura 6. Links entre objetivos e indicadores e outras fases da AAE .66

Figura 7. Sistema institucional da gestão do turismo no Brasil .76

Figura 8. Meios de transporte utilizados no turismo internacional. .87

Figura 9. Distribuição percentual do consumo mundial de petróleo por setor, ano 2000 .88

Figura 10. Localização dos municípios da região de montante da Bacia Hidrográfica do rio Mogi-Guaçu 143

Figura 11. Entrevistas com a população local e turistas 146

Figura 12. Entrevistas com a população local e turistas 146

Figura 13. Mapa do Estado de Minas Gerais 148

Figura 14. Paisagem montanhosa do município de Bueno Brandão e cachoeira dos Luis. 148

Figura 15. Área de pasto na zona rural de Bueno Brandão 149

Figura 16. Pousada junto à Cachoeira dos Félix 151

Figura 17. Paisagem com fragmentos de vegetação nativa 151

Figura 18. Turistas e cachoeiras na área rural de Bueno Brandão 152

Figura 19. Turistas e cachoeiras na área rural de Bueno Brandão 152 
Figura 20. Chalés de pousadas de Bueno Brandão ....................................................153

Figura 21. Chalés de pousadas de Bueno Brandão ..................................................153

Figura 22. Prefeitura Municipal de Bueno Brandão ................................................153

Figura 23. Grau de conhecimento sobre turismo dos moradores de Bueno Brandão..165

Figura 24. Disposição dos moradores de Bueno Brandão em participar das decisões

do desenvolvimento turístico no município...............................................................166 


\section{LISTA DE QUADROS}

Quadro 1. Possíveis ações estratégicas sujeitas à $A A E$

Quadro 2. A prática da avaliação de impacto em cascata em um sistema de planejamento de turismo

Quadro 3. Exemplos de termos utilizados para designar diferentes tipos de avaliações ambientais estratégicas

Quadro 4. Dispositivos institucionais para adoção da AAE em alguns países .53

Quadro 5. AAE do Plano de Neiafu, Vava'u, Tonga 111

Quadro 6. AAE do Programa de atividades da região central de Ottawa, Canadá ......112

Quadro 7. AAE do Plano de Desenvolvimento do Turismo nas Ilhas Fiji. 113

Quadro 8. AAE do Macro zoneamento da região das praias de Tofo, Barra, Tofinho e

Rocha, Moçambique 114

Quadro 9. AAE do Programa Setorial de Turismo, República Checa 115

Quadro 10. AAE do Plano de Desenvolvimento do Município de Varna, Bulgária 116

Quadro 11. Avaliação ambiental programática do turismo em Cochabamba, Bolívia ..117

Quadro 12. AAE do Plano de Desenvolvimento de Victoria Falls, Zimbábue e

Zâmbia 118

Quadro 13. Avaliação ambiental programática na região do Mar Vermelho, Egito

Quadro 14. AAE do Programa Nacional de Desenvolvimento do Turismo, Bielo-

Rússia 120

Quadro 15. AAE da Estratégia Nacional de Turismo, Honduras 121

Quadro 16. AAE da Estratégia Nacional de Turismo, México 122

Quadro 17. AAE do Plano de Desenvolvimento do Turismo em Oymapinar, Turquia .123 
Quadro 18. Avaliação de impacto para a sustentabilidade do turismo na Comunidade

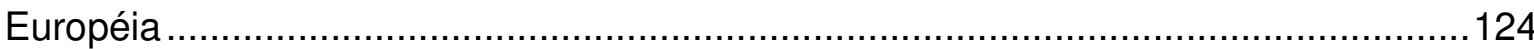

Quadro 19. Localização dos estudos de caso analisados........................................126

Quadro 20. Âmbito de aplicação dos estudos de caso de AAE de turismo...................128

Quadro 21. Momento de realização das AAEs de Turismo.........................................130 


\section{LISTA DE TABELAS}

Tabela 1 - Áreas naturais protegidas no mundo......................................................90

Tabela 2 - Produto Interno Bruto a preços correntes ............................................150 


\section{SUMÁRIO}

1 INTRODUÇÃO

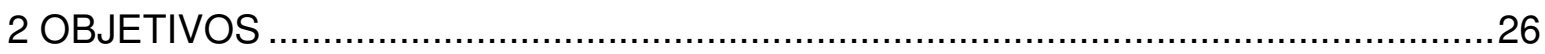

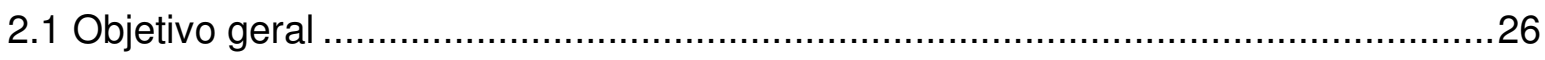

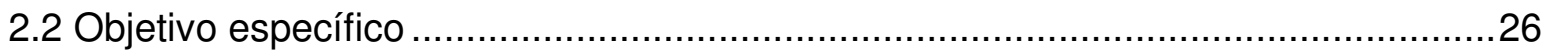

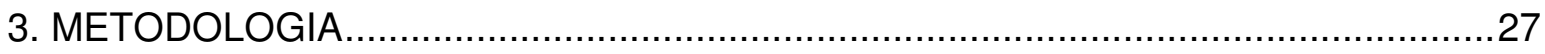

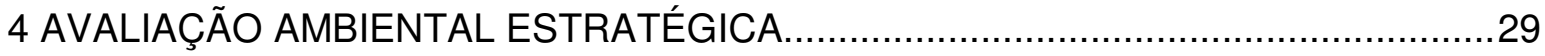

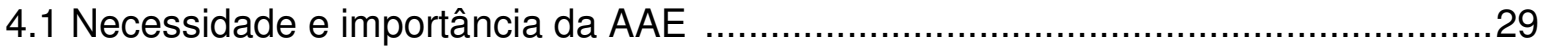

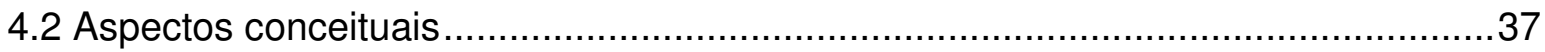

4.3 Experiências e aplicação da AAE no mundo ...........................................................

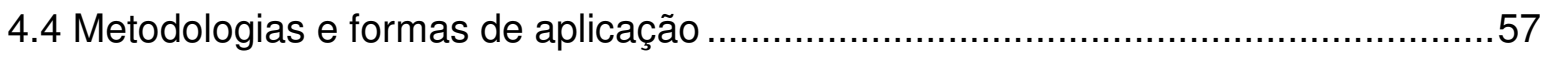

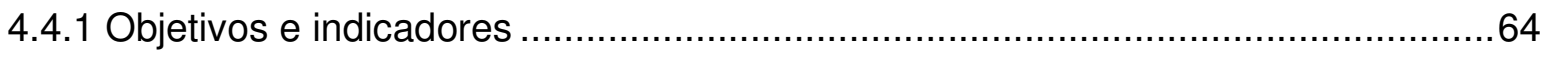

4.4.2 Base ambiental e problemas ambientais pertinentes ........................................67

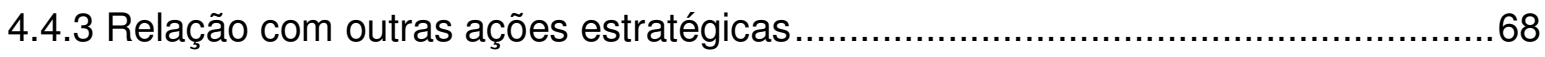

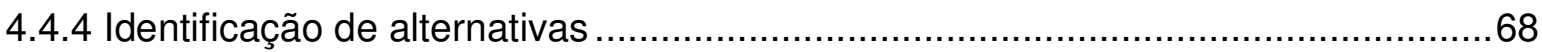

4.4.5 Previsão, avaliação e mitigação de impactos ....................................................69

4.4.6 Documentação, implementação e monitoramento ……………………………......71

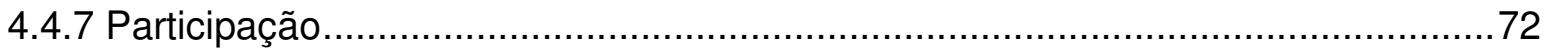

4.5 Desafios para adoção da AAE no setor de turismo no Brasil ......................................73

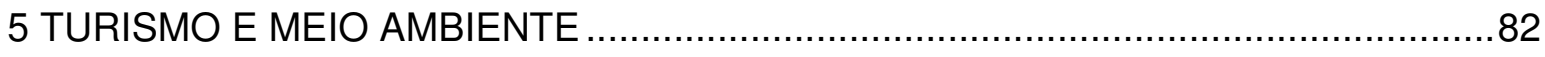

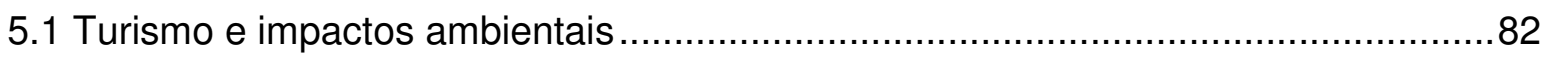

5.2 Instrumentos de gestão ambiental para o turismo ................................................95

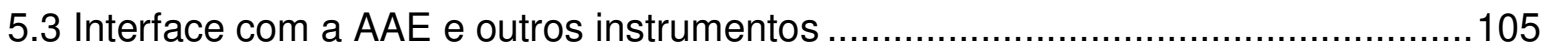

6 TURISMO E AVALIAÇÃO AMBIENTAL ESTRATÉGICA......................................109

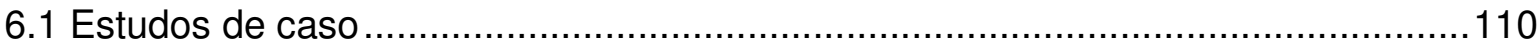

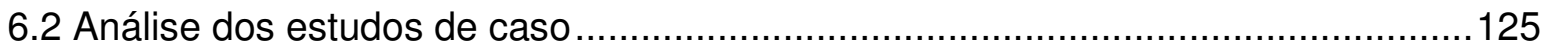




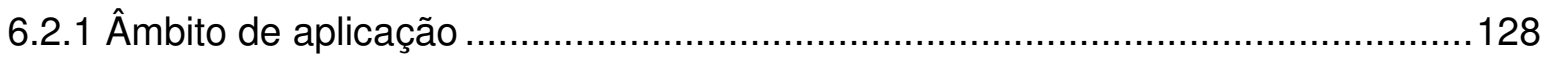

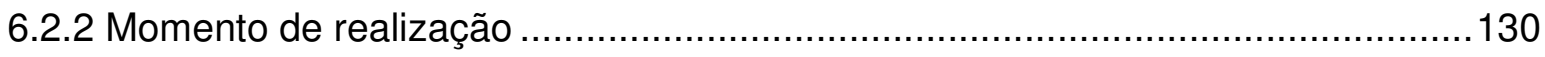

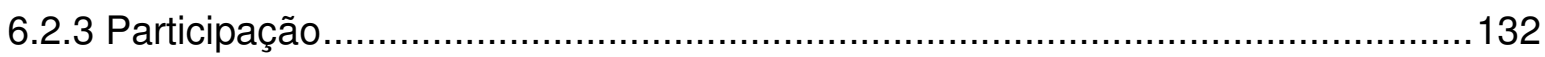

6.2.4 Responsabilidade pela condução da AAE.................................................133

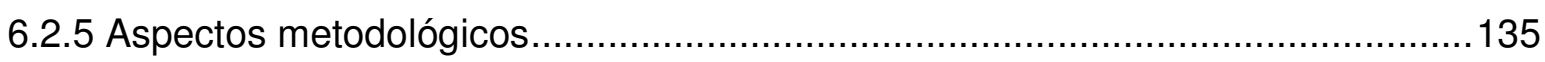

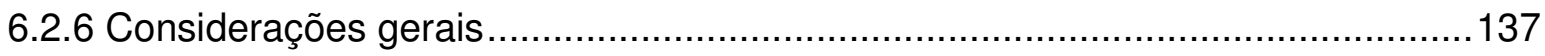

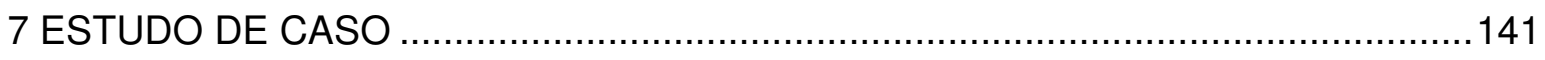

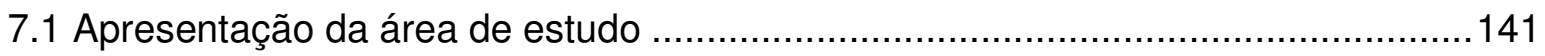

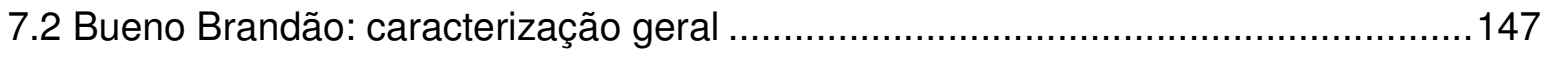

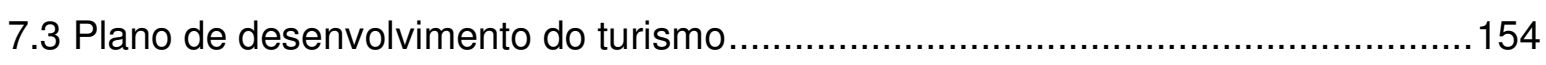

7.4 Subsídios para avaliação ambiental estratégica .................................................155

7.4.1 Estrutura administrativa e institucional de gestão do turismo em Bueno

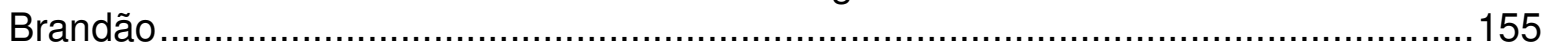

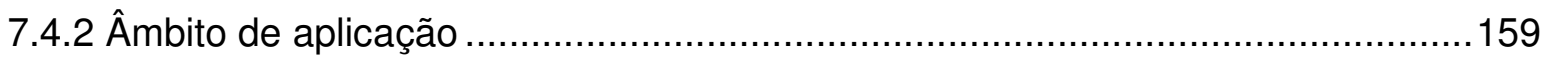

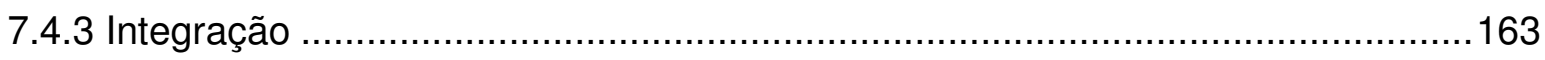

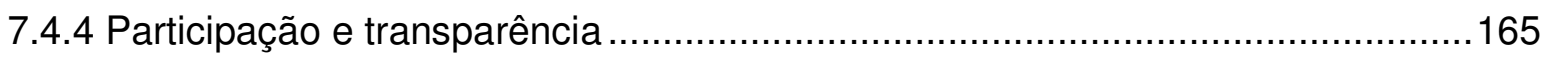

7.4.5 Referências, informações e monitoramento ………………………………........169

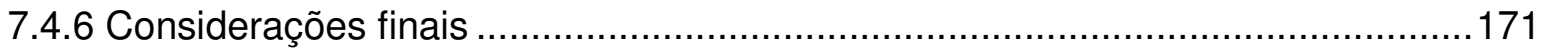

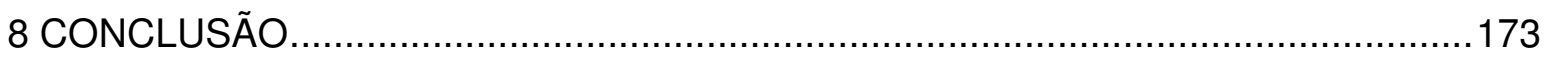

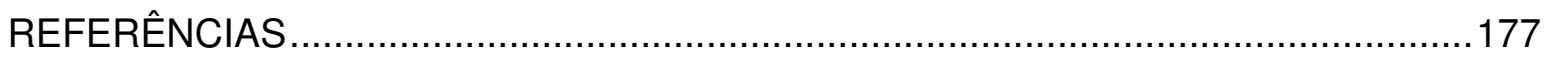




\section{INTRODUÇÃO}

Ao contestar e questionar pilares da sociedade moderna, a crise ecológica global tornou-se nas últimas três décadas um dos maiores desafios da humanidade (FREY, 2000). É a partir desse momento, quando as atividades humanas passaram a modificar e a impactar cada vez mais o meio natural e os problemas ambientais foram sentidos em todas as partes do mundo, que os questionamentos em torno dessa temática tomaram corpo e entraram na pauta de discussões do mundo.

Um dos primeiros encontros mundiais, que reuniu cientistas, economistas e membros de governos, em que a problemática ambiental ganhou destaque foi o chamado Clube de Roma. O grande marco, porém, foi a Conferência das Nações Unidas sobre o Meio Ambiente Humano, ocorrida em 1972, que ensejou tantos outros encontros e conferências mundiais e, posteriormente, por meio do chamado Relatório Brundtland, propagou a idéia do desenvolvimento sustentável (COMISSÃO MUNDIAL SOBRE MEIO AMBIENTE E DESENVOLVIMENTO, 1991).

Esse conceito surge como alternativa às teorias e modelos tradicionais de desenvolvimento apresentados até então. Uma das definições mais utilizadas e citadas é aquela propagada pelo próprio Relatório Brundtland, que entende como desenvolvimento sustentável aquele que atende às necessidades e aspirações do presente, sem comprometer a possibilidade de atendê-las no futuro. A perspectiva defendida pela Comissão postula o crescimento econômico e torna a superação do subdesenvolvimento no hemisfério sul dependente do crescimento contínuo dos países industrializados, o que, segundo Brüseke (1995), põe em dúvida a coerência dessa posição do ponto de vista ecológico. Assim, o tom diplomático e o fato de o 
relatório não propagar a despedida do crescimento e poupar críticas à sociedade industrial e aos países industrializados faz com que o conceito de desenvolvimento sustentável apresentado pelo relatório seja tão atraente e amplamente aceito.

Outros acreditam que só uma mudança radical de paradigmas e dos modos de produção e consumo atuais podem garantir um desenvolvimento sustentável. Sachs (2002) assinala que o desenvolvimento sustentável é, evidentemente, incompatível com o jogo sem restrições das forças de mercado, pois estas são demais míopes para considerar questões que não sejam lucros. Leff (2002) também defende uma reorientação das práticas produtivas para 0 alcance do desenvolvimento sustentável já que a crise ambiental de hoje problematiza os paradigmas da atualidade e demanda novas metodologias capazes de orientar uma reconstrução.

Nota-se, portanto, que, desde que surgiu, o conceito de desenvolvimento sustentável é utilizado e defendido de uma forma muito ampla e que, dependendo da ocasião, pode significar coisas diversas e se materializar de formas diferentes.

Frey (2001) analisa diferentes abordagens e apropriações da expressão e explica as três principais concepções de desenvolvimento sustentável presentes na bibliografia. São elas as abordagens econômico-liberal de mercado, ecológicotecnocrata de planejamento e a política de participação democrática.

A abordagem econômico-liberal de mercado aposta nas "forças de autoregulação do mercado", e pressupõe que a pressão da concorrência, o crescimento econômico e a prosperidade levam automaticamente ao uso racional dos recursos naturais, ao progresso tecnológico e a novas necessidades de consumo compatíveis com as exigências do meio ambiente. O conceito de desenvolvimento sustentável do Relatório Brundtland é representativo dessa abordagem, pois suas preocupações 
enfatizam os efeitos nocivos da pobreza para o meio ambiente em detrimento da crítica do estilo nocivo de desenvolvimento praticado nos países industrializados, tornando esse princípio aceitável, inclusive para essas nações dominantes.

A abordagem ecológico-tecnocrata parte da idéia da possibilidade de planejar a sustentabilidade do desenvolvimento, em que a superação dos problemas ambientais é perseguida por meios gerenciais, confiando na expertise profissional da intervenção estatal. Na prática, ela freqüentemente vem acompanhada de uma atitude tecnocrata e centralizadora e costuma esbarrar com freqüência nos diversos interesses que se articulam no processo político.

Na abordagem política de participação democrática, a participação popular torna-se peça fundamental da política ambiental, indispensável para uma mudança substancial do atual quadro de políticas públicas. Dessa forma, planejamento é compreendido não apenas como orientado pelas necessidades da população, mas também como conduzido por ela. Essa idéia baseia-se na avaliação de que a solução dos problemas sócio-ambientais não depende, em primeiro lugar, do alcance de crescimento econômico, nem de melhor compreensão científica, mas sim da superação de conflitos da distribuição e criação de justiça social, tratando-se, portanto, de uma questão eminentemente política.

Assim, da mesma forma que existem diversos modos de se entender e conceber o desenvolvimento sustentável, as orientações práticas, os instrumentos e as políticas pró-sustentabilidade também se expressam de modo muito variado. Leff (2002) acentua que pôr em prática princípios e estratégias de ecodesenvolvimento, ou desenvolvimento sustentável, provou ser mais complexo e difícil do que a simples internalização de uma "dimensão ambiental" dentro dos atuais paradigmas 
econômicos, dos instrumentos de planejamento e das estruturas institucionais que sustentam a racionalidade produtiva prevalecente.

Talvez não seja possível à sociedade, em nome do desenvolvimento sustentável, reformular radicalmente o atual modelo de desenvolvimento, mediante a ruptura com os atuais modos de produção, centrados na lógica do lucro e das leis de mercado. A política de participação democrática, porém, pode oferecer meios para a descoberta de novas formas de distribuição de poder entre o Estado, o setor privado e o terceiro setor. Essa nova forma de se fazer política pode ser extremamente benéfica para inserir a questão ambiental na pauta das discussões juntamente com outras questões estratégicas.

Para isso também se fazem necessários novos instrumentos econômicos, jurídicos e técnicos, como os métodos de avaliação de impacto ambiental, indicadores e padrões de qualidade ambiental e procedimentos legais em defesa dos valores e dos direitos ambientais. Além disso, é importante realçar a força social que limita o uso da lei de mercado por uma classe e busca conciliar interesses ambientais diversos e elevar o bem comum pela intervenção do Estado e a participação da sociedade civil (LEFF, 2002).

Brüseke (1995) acredita que o desenvolvimento, não acompanhado da intervenção do Estado e das correções partindo da sociedade civil, desestrutura a composição social, a economia territorial e seu contexto ecológico. Por isso, o autor defende uma perspectiva multidimensional, como ponto de partida da teoria do desenvolvimento sustentável, envolvendo economia, ecologia e política ao mesmo tempo. Já Sachs (1993) também destaca a emergência da sociedade civil na cena política como o terceiro sistema de poder, ao lado dos Estados e do poder 
econômico, desempenhando um papel significativo no aumento do status político das questões ambientais.

A busca por modelos de desenvolvimento mais sustentáveis se materializa de formas diferentes, porém, a necessidade da intervenção do Estado e da participação da sociedade, como meios para equilibrar a distribuição de poder e rechaçar formas de desenvolvimento centradas na lógica de mercado, é destacada por diversos autores e teóricos do desenvolvimento sustentável.

Já existem diversos instrumentos que visam à gestão ambiental, estimulando abordagens preventivas, assim como novas formas e esferas de participação da sociedade. Pode-se mencionar o caso do Brasil o qual, em 1981, aprovou a Política Nacional de Meio Ambiente, que estabeleceu como alguns de seus instrumentos o zoneamento ambiental, a avaliação de impacto ambiental (AIA), o licenciamento de atividades efetiva ou potencialmente poluidoras, a criação de espaços territoriais especialmente protegidos, dentre outros. Da mesma forma, como lembra Leis (1999), o País dispõe de várias formas e canais de participação dos cidadãos e organizações da sociedade civil como os procedimentos de ação civil pública, os órgãos colegiados como o Conselho Nacional do Meio Ambiente - CONAMA e outros órgãos deliberativos estaduais e municipais do mesmo tipo, e a avaliação de impacto ambiental.

A avaliação de impacto ambiental ganha destaque por já ser amplamente utilizada em várias partes do mundo, como um instrumento de planejamento para demonstrar viabilidade ambiental, prever e avaliar os impactos de atividades nas suas diferentes escalas, sejam elas políticas, planos, programas ou projetos e suas alternativas. Além disso, ela pressupõe a participação da sociedade a fim de que 
sua opinião a respeito das questões ambientais possa ser considerada no momento de tomada de decisão (ORTOLANO e SHEPHERD, 1995).

A sua adoção, a partir da década de 1970, representou, desde o início, um avanço em relação à maneira como as questões ambientais eram tratadas na esfera pública. Isso porque, segundo Barbieri (1997), as ações para coibir os principais problemas ambientais eram principalmente de natureza reativa, corretiva e repressiva, tais como proibições, multas e outras ações de combate aos efeitos gerados pelos processos de produção e consumo. Assim, com o tempo, às práticas corretivas e repressivas somaram-se novos instrumentos de intervenção governamental voltados para a prevenção da poluição e a melhoria dos sistemas produtivos.

A inserção da AIA em países em desenvolvimento, dentre eles o Brasil, tem sua origem na atuação de agentes financeiros multilaterais e de outras organizações internacionais de fomento, mas, principalmente, nas próprias condições internas desses países, que propiciaram uma acolhida às práticas e princípios de prevenção e de precaução inerentes à AIA, e no estilo de desenvolvimento adotado mundialmente, que engendra formas semelhantes de degradação ambiental (SÁNCHEZ, 2006).

No Brasil, portanto, a AIA também representou um avanço no trato das questões ambientais e já é bastante utilizada, no âmbito da avaliação de projetos, na tentativa de garantir a consideração das questões ambientais e a participação dos cidadãos e da sociedade civil nas tomadas de decisão.

Porém, apesar da relevância que esse instrumento alcançou no decorrer dos anos, a avaliação de impactos não esteve imune a críticas quanto à sua capacidade de garantir que os projetos de desenvolvimento estejam de acordo com a 
capacidade de suporte do meio. Assim, há alguns anos, pesquisadores e planejadores enfatizam as limitações da avaliação de impacto ambiental. Morris e Therivel (1995) chamaram atenção para a necessidade da avaliação de impacto em situações mais estratégicas, como políticas, planos e programas (PPPs), regionais e setoriais.

Apesar do avanço na maneira de perceber os problemas ambientais, os governos e instituições ainda não são capazes de garantir que as conseqüências ambientais de suas decisões sejam amplamente consideradas no momento da elaboração de políticas governamentais. Tratando desse assunto, Souza (2000) destaca o fato de que, considerando o caráter de bem comum do meio ambiente, o Estado desempenha papel importante no trato dos problemas ambientais e que, por isso, ao perseguir o bem-estar comum, os governos devem fazer com que suas políticas incorporem a perspectiva ambiental, buscando assim a consecução dos pressupostos do desenvolvimento sustentável.

O documento da Agenda 21, o plano de ação para o desenvolvimento sustentável, em seu capítulo 8, também destaca a importância da integração entre desenvolvimento e meio ambiente na tomada de decisão. Esse capítulo enfatiza a necessidade de consideração dos fatores econômicos, sociais e ambientais na formulação de políticas públicas, além de garantir uma participação maior do público, buscando, assim, maior coerência entre políticas, planos e instrumentos das políticas setoriais, econômicas, sociais e ambientais (BARBIERI, 1997).

Ortolano e Shepherd (1995) também já relevavam o fato de que a influência dos estudos de impacto poderia ser bem mais significativa se estes fossem aplicados em níveis mais estratégicos, fornecendo oportunidades para mitigar ou até 
abandonar concepções ambientalmente incorretas, antes que elas se transformem em projetos.

A realidade mostra que nem sempre esses estudos conseguem dar respostas satisfatórias à sociedade. Souza (2000) afirma que a AIA, em muitos casos, é vista como um procedimento técnico e burocrático e não conduz a níveis desejados de qualidade ambiental.

Isso porque, em muitas situações, o estudo de impacto ambiental (EIA) não está integrado ao planejamento e elaboração dos projetos em questão. Pelo contrário, na maioria das vezes, um investidor não despenderá esforços para realizar um EIA, até que o projeto esteja bem definido e exista grande possibilidade de que ele seja aprovado (ORTOLANO e SHEPHERD, 1995).

Além disso, citando o caso do Brasil, Agra Filho (2002) observa que os instrumentos da política ambiental aplicados no País possuem precária capacidade de integração da política ambiental com as demais políticas públicas. Essa precariedade não somente torna evidente o reducionismo técnico de que esses instrumentos se revestem, como também revela sua extrema vulnerabilidade ao contexto político em que serão aplicados.

Nesse contexto, surge a avaliação ambiental estratégica (AAE), que representa uma forma que se convencionou adotar para identificar o processo formal de avaliação, o mais cedo possível, dos impactos ambientais de decisões tomadas em políticas, planos e programas (PARTIDÁRIO, 1996).

O Congresso dos Estados Unidos estabeleceu as bases para a difusão da idéia de avaliação ambiental estratégica ao aprovar, em 1969, o chamado NEPA The National Environmental Policy Act, exigindo avaliação dos efeitos ambientais de propostas de lei ou outras ações do Governo federal que pudessem afetar 
significativamente o meio ambiente. A intenção desse requisito era auxiliar os responsáveis pela tomada de decisão e planejadores na escolha de diferentes alternativas de planos e programas, levando em consideração critérios ambientais (PARTIDÁRIO e CLARK, 2000).

A avaliação ambiental estratégica, portanto, surge como instrumento de consideração e avaliação das questões ambientais em situações estratégicas, antes que importantes decisões tenham sido tomadas, ou seja, nas diferentes etapas de formulação de políticas públicas e planejamento.

Assim, além de possivelmente compensar algumas limitações dos estudos de impacto ambiental de projetos, a avaliação ambiental estratégica é vista como um instrumento com grande potencial de promoção do desenvolvimento sustentável. Isso porque, segundo Therivel e Partidário (1996), essa ferramenta deve proporcionar a consideração de todas as implicações ambientais de planos governamentais e realçar o papel dessas políticas como indutoras de formas mais sustentáveis de desenvolvimento.

O propósito da AAE, portanto, é o de incorporar às tomadas de decisão a consideração, o mais cedo possível, das suas conseqüências ao meio ambiente, assim como as necessidades da sociedade. Esse conceito também considera como parte do processo a consulta pública e a análise de alternativas, antes que haja comprometimento irreversível de recursos para certas políticas, planos e programas (CLARK, 2000).

Após a provação do NEPA pelo Congresso dos Estados Unidos, a discussão e a aplicação de avaliações ambientais, em níveis mais estratégicos como políticas, planos e programas, evoluíram significativamente em diversos países, principalmente a partir da década de 1980. No Brasil, porém, apesar do avanço na 
adoção da AIA, como instrumento da política nacional do meio ambiente, ela ainda é adotada de maneira restrita, apenas em projetos.

Nos últimos anos, houve aumento significativo na prática, na pesquisa e na discussão a respeito da $A A E$, seus conceitos, objetivos, metodologias, âmbito de aplicação etc. No Brasil, porém, o assunto ainda é tratado em canais restritos e as tentativas de aplicação desse instrumento ainda acontecem de modo muito pontual e experimental.

O presente estudo, portanto, pretende ampliar a discussão sobre o assunto, tratando os aspectos conceituais, analisando a prática internacional e oferecendo subsídios para a adoção desse instrumento no Brasil, com ênfase no setor de turismo.

Isso porque o turismo é hoje uma das atividades econômicas de maior pujança e expressão mundial. Segundo a Organização Mundial do Turismo (OMT) (2005) o ano de 2005 atingiu uma marca recorde em relação ao número de passageiros internacionais, chegando ao valor 806 milhões de turistas, um crescimento de 5,5\% em relação ao ano anterior. Em números absolutos, as receitas do turismo internacional atingiram, nesse mesmo ano, o valor estimado de 680 bilhões de dólares. É uma atividade que não pára de crescer, com quase todos os anos, desde o início da década de 1990, apresentando taxas positivas de crescimento. Para 2020, a OMT espera o número de 1,6 bilhão de turistas internacionais.

No Brasil, a realidade não é muito diferente do cenário internacional. $O$ turismo no País é estimulado, como em muitos outros países em desenvolvimento, como uma alternativa econômica de geração de emprego e renda. Além de permitir a entrada de divisas, o turismo emprega considerável quantidade de mão-de-obra e 
estimula indiretamente vários setores da economia como o da construção civil, o comércio, o setor de bebidas, transporte, comunicação, dentre outros.

Mas, assim como outros setores da economia mundial, esse desenvolvimento traz conseqüências ao meio ambiente natural e essas questões muitas vezes não recebem atenção no momento da elaboração de políticas setoriais.

Além disso, a generalização e globalização da problemática ambiental impôs sobre diversas disciplinas o imperativo de internalizar em seus paradigmas metodológicos e teóricos os efeitos e problemas práticos do desenvolvimento econômico (LEFF, 2002). Com o turismo não é diferente, e diversos estudos mostram as conseqüências negativas que formas predatórias de turismo podem causar no meio natural e a necessidade de se buscar instrumentos que garantam o desenvolvimento responsável e sustentável da atividade.

Por isso, este trabalho evidencia as perspectivas de aplicação da avaliação ambiental estratégica para o planejamento turístico, trazendo uma análise sobre a relação turismo e meio ambiente, os instrumentos utilizados para a gestão ambiental da atividade e as experiências de aplicação da AAE em turismo. O referencial teórico que aqui se segue traz também uma retrospectiva da evolução conceitual e prática da avaliação ambiental estratégica, as tendências metodológicas e os desafios para sua adoção no Brasil.

Por fim, foi realizado um estudo de caso no Município brasileiro de Bueno Brandão, no Estado de Minas Gerais, através do qual se buscou oferecer subsídios para inserção da avaliação ambiental estratégica no plano municipal de desenvolvimento turístico. 


\section{OBJETIVOS}

\subsection{Objetivo geral}

Avaliar possibilidades e desafios para a aplicação da avaliação ambiental estratégica como um instrumento de planejamento e gestão do turismo no Brasil.

\subsection{Objetivo específico}

Oferecer subsídios e recomendações para uma possível aplicação da avaliação ambiental estratégica em um plano de desenvolvimento turístico do Município de Bueno Brandão, Minas Gerais. 


\section{METODOLOGIA}

Para atingir os objetivos estabelecidos na pesquisa, foi realizado levantamento bibliográfico sobre o tema, o que acompanhou todas as fases do trabalho. Partiu-se do princípio de que era preciso, primeiramente, conhecer a avaliação ambiental estratégica e as questões-chave que envolvem a relação turismo e meio ambiente. A pesquisa bibliográfica, portanto, diz respeito a todo o arcabouço teórico referente a:

- $\quad$ aspectos conceituais e metodológicos da AAE; e

- a relação turismo e meio ambiente, impactos ambientais da atividade e instrumentos de gestão.

Além disso, foi feita uma análise da experiência prática internacional referente à aplicação da $\mathrm{AAE}$, com ênfase no setor do turismo, por intermédio de 14 estudos de caso. Essas experiências foram confrontadas com alguns princípios que envolvem a aplicação da AAE. Foram identificados os âmbitos de aplicação, os resultados alcançados e desafios a serem superados nesse campo, com o intuito de gerar subsídio e base ao trabalho aplicado.

Na última fase da pesquisa, um estudo de caso no Município de Bueno Brandão permitiu confrontar os princípios indispensáveis para a realização da AAE e as lições aprendidas da experiência internacional com a realidade de um município brasileiro de potencial turístico. 
Para isso foi necessária a realização de pesquisa direta, com observações diretas em campo e pesquisa documental. Isso porque, segundo Beni (2001), por mais lógica, coerente e precisa que seja toda e qualquer apresentação teórica, esta nunca deve prescindir do embasamento da pesquisa feita junto aos órgãos, entidades e pessoas que acionam a matéria objeto do estudo, pois é esta investigação prática e concreta que poderá oferecer possíveis correções no encaminhamento de factíveis intervenções na realidade.

Por isso, a pesquisa versou sobre os principais aspectos que envolvem a gestão do turismo no Município, ou seja, a maneira pela qual o Poder público local se organiza e se aparelha para administrar o setor de Turismo, os instrumentos de gestão utilizados, as esferas de participação da sociedade, as informações ambientais disponíveis e outros fatores e princípios indispensáveis para se realizar uma avaliação ambiental estratégica. 


\section{AVALIAÇÃO AMBIENTAL ESTRATÉGICA}

\subsection{Necessidade e importância da AAE}

Os principais motivos que levam pesquisadores a defenderem o uso da $A A E$ são a possibilidade desse instrumento envolver um processo de avaliação de impacto mais amplo que o restrito a projetos, a inserção da questão ambiental na tomada de decisão, a contribuição para políticas, planos e programas mais sensíveis à questão ambiental, a promoção de princípios do desenvolvimento sustentável e o aumento da transparência e do envolvimento da sociedade na discussão e na tomada de decisão de questões estratégicas.

Considerando-se as imperfeições e limitações da avaliação de impacto ambiental de projetos, acredita-se que a incorporação de seus princípios em políticas, planos e programas poderá estabelecer um contexto mais favorável a empreendimentos ambientalmente corretos, assim como há de desencorajar ou até mesmo evitar aqueles mais prejudiciais.

Levando em conta o planejamento como uma seqüência de variados níveis de tomada de decisão, que vão desde as questões mais estratégicas discutidas nas políticas até a concepção de projetos, como mostrado em seguida, com cada nível influenciando a ação subseqüente, resta claro entender de que forma os projetos de desenvolvimento são conseqüência e resultado de decisões tomadas anteriormente, em situações mais estratégicas. Assim, conforme ilustra a figura 1, a adoção da AAE permite que a análise e avaliação de alternativas estratégicas sejam realizadas na 
ocasião adequada, ou seja, no momento da elaboração de políticas, planos e programas.

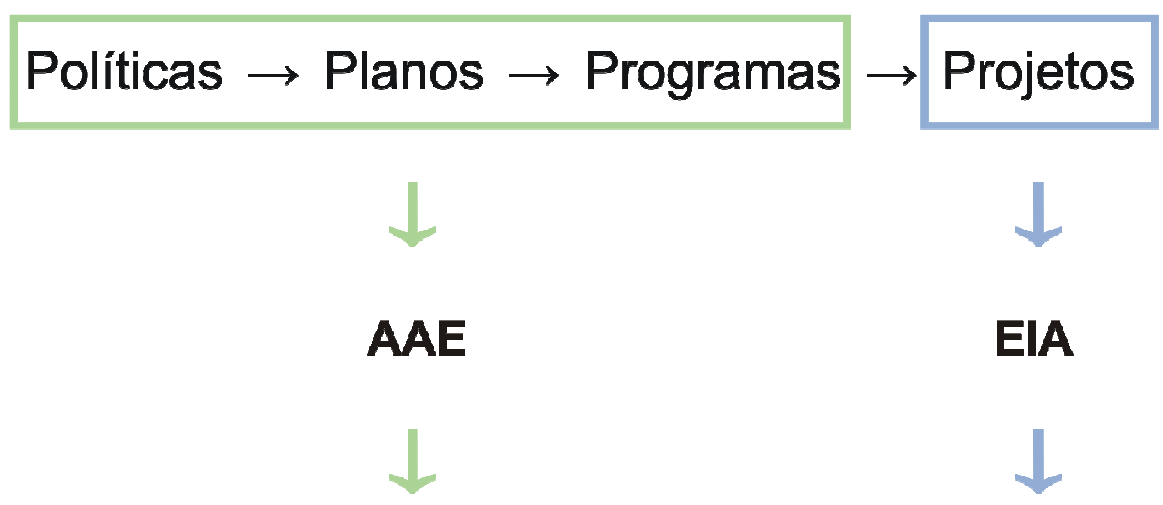

\section{Avaliação de alternativas estratégicas}

\section{Avaliação de alternativas locacionais e tecnológicas}

Figura 1. Avaliação de alternativas nos diferentes níveis de tomada de decisão

Partidário (2000) afirma que, inicialmente, as vantagens da AAE em relação ao fortalecimento dos estudos de impacto ambiental não eram sempre muito óbvias. As primeiras abordagens e experiências de $A A E$ não pareciam compensar as deficiências dos estudos de impacto de projetos, e, como essas vantagens não apareciam de forma clara e evidente, a AAE era, muitas vezes, vista como um algo ineficaz.

Cada vez mais, no entanto, se acredita que em situações em que uma política, plano ou programa antecede e influencia o desenvolvimento de projetos, a avaliação ambiental estratégica pode desempenhar papel significativo no sentido de 
compensar limitações da avaliação ambiental de projetos, mediante a incorporação das questões ambientais em todos os níveis da tomada de decisão.

Um exemplo disso é a análise que Nooteboom (2000) faz de algumas experiências de aplicação da AAE e sua relação com os diferentes níveis de tomada de decisão (políticas, planos, programas e projetos). $\mathrm{O}$ autor mostra como as avaliações ambientais em níveis estratégicos podem realmente reduzir a abrangência e o escopo dos estudos de impacto ambiental de ações subseqüentes. É o que ele denomina de funnelling effect, em que os impactos e as alternativas considerados vão sendo cada vez mais restringidos e focalizados nas questões que realmente podem ser influenciadas pelo poder de decisão do nível estratégico e de planejamento em questão.

A AAE, portanto, estando presente em todos os níveis de planejamento (ver figura 2), pode realmente aperfeiçoar a avaliação de impacto como um todo, refinando as questões ambientais que realmente interessam, avaliando e selecionando as alternativas ambientalmente mais viáveis e, portanto, reduzindo tempo e esforços das avaliações subseqüentes. 


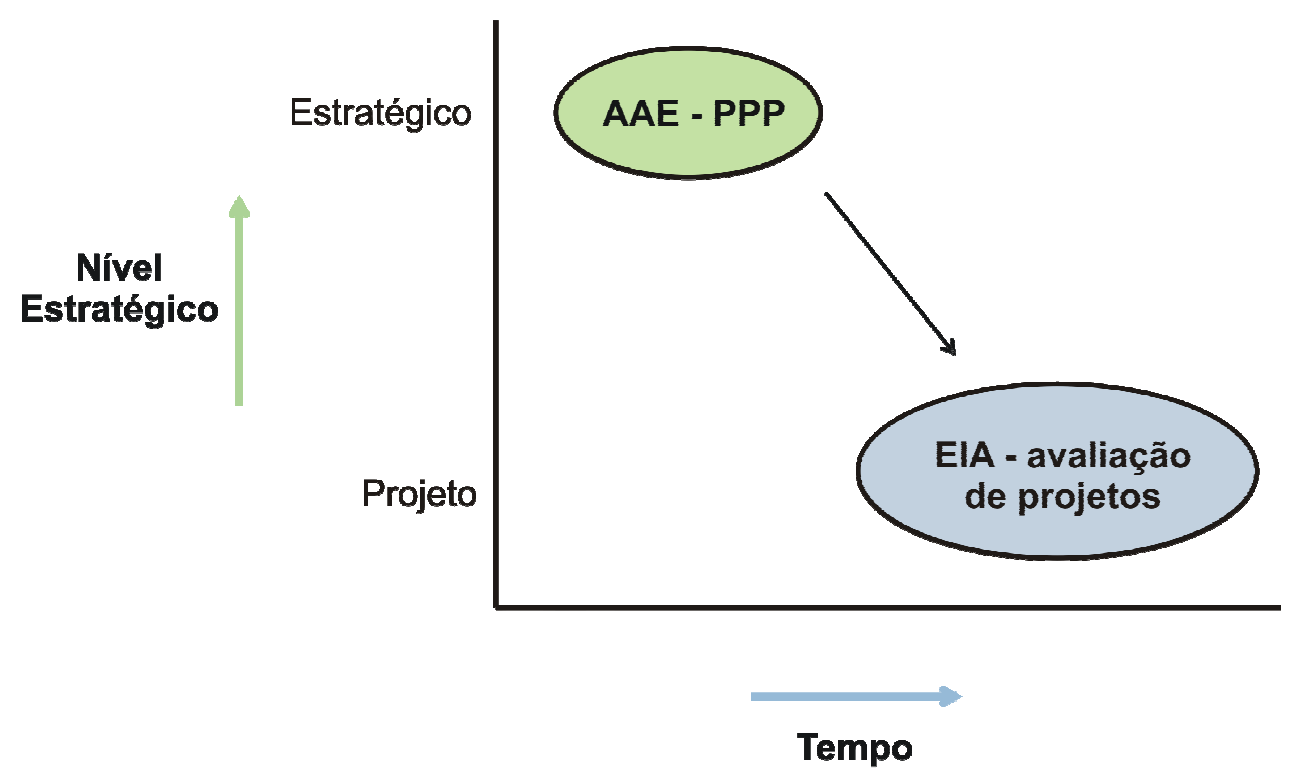

Figura 2. Um típico modelo de seqüência de níveis hierárquicos de políticas Fonte: Adaptado de Nooteboom (2000)

Com efeito, espera-se que, como uma conseqüência da $\mathrm{AAE}$, políticas e planos incorporem os requisitos necessários para o posterior desenvolvimento de projetos mais sensíveis à questão ambiental (PARTIDÁRIO, 1996).

Além disso, a AAE pode lidar com várias dificuldades enfrentadas no ato da avaliação de projetos. Therivel e Partidário (1996) chamam a atenção para o fato de que os estudos de impacto ambiental de projetos, geralmente, se limitam a analisar os impactos diretos do empreendimento, não levando em consideração os seguintes efeitos:

- impactos aditivos, num contexto de vários empreendimentos de pequena escala. É o caso de pequenos empreendimentos turísticos (meios de hospedagem, centros de lazer), para os quais o estudo de impacto ambiental 
não é exigido individualmente, mas, se concentrados numa mesma região geográfica, podem resultar em impactos ambientais significativos.

- Impactos induzidos, quando um empreendimento estimula projetos secundários. Por exemplo, a construção de estradas pode acarretar a pressão pelo desenvolvimento turístico de áreas muito sensíveis, com pouca estrutura para receber fluxos turísticos e até então preservadas em razão da dificuldade de acesso.

- Impactos sinérgicos, quando o impacto total de vários empreendimentos excede a soma de seus impactos individuais. Por exemplo, vários hotéis localizados em balneários ou estâncias termais podem isoladamente ocasionar um impacto pequeno sobre o lençol freático do local. A concentração desses empreendimentos, porém, pode implicar um consumo anual total de água superior à capacidade de recarga do lençol freático.

- Impactos globais, como é o caso dos efeitos do desenvolvimento sobre a biodiversidade ou sobre a emissão de gases causadores do efeito estufa. No turismo, os estudos de impacto ambiental não se apresentam suficientes para avaliar as conseqüências que o deslocamento de pessoas pode ocasionar sobre a emissão de gases, a introdução de espécies exóticas e a perda da biodiversidade.

Sánchez (2006) lembra que, no Brasil, os procedimentos relativos aos estudos de impacto ambiental, previstos na Resolução Conama 1/86, devem necessariamente incluir as propriedades cumulativas e sinérgicas do empreendimento avaliado. Na prática, porém, o autor identifica algumas questões que limitam a análise de impacto cumulativo em avaliação de projetos, 
especialmente aquelas relacionadas à dificuldade ou mesmo impossibilidade de se obter informações sobre projetos futuros, fato que diz respeito a questões de ordem institucional ou mesmo legal (acesso a informação de agentes privados).

Além disso, tradicionalmente, os estudos de impacto ambiental não se ocupam de impactos insignificantes ou de baixa significância, tampouco de ações que, tomadas individualmente, tenham baixo potencial de causar impactos significativos. Assim, a contribuição e significância desses impactos para problemas ambientais de larga escala devem ser tratadas por um outro instrumento, com uma perspectiva mais abrangente e estratégica (SÁNCHEZ, 2006).

O estudo de impacto ambiental de projetos, portanto, é insuficiente para avaliar questões mais estratégicas como os impactos indiretos e globais de um empreendimento; ou, como instrumento para garantir o desenvolvimento mais sustentável de um setor, como é o caso do turismo. Acredita-se, portanto, que, com a avaliação ambiental estratégica, essas questões sejam avaliadas no momento do planejamento de ações estratégicas, como políticas, planos e programas.

Por outro lado, pode-se argumentar que, em muitos setores e esferas governamentais, as questões ambientais já são integradas ao planejamento, via de regra, mediante a elaboração de políticas ambientais setoriais, manual de boas práticas ou estabelecimento de medidas mitigadoras.

Por isso, inicialmente, muito se argumentava que os princípios da avaliação ambiental estratégica já vinham sendo adotados e faziam parte da tomada de decisão em muitos países e que a incorporação da AAE de uma forma sistemática não representaria ganhos ou benefícios significativos em relação ao que vinha sendo feito (PARTIDÁRIO, 2000). 
De fato, nos últimos anos, com o aumento da conscientização ambiental e da preocupação em relação às conseqüências ambientais do desenvolvimento, tanto o setor público como a iniciativa privada procuram, de várias maneiras, incorporar as questões ambientais em suas diversas formas de atuação. Essas iniciativas podem significar importante passo na integração das questões ambientais dentro da tomada de decisão e do planejamento, e a AAE é a forma que se encontrou de sistematizar esse processo.

Promover melhores práticas ambientais ou medidas mitigadoras para políticas e setores que podem causar impactos significativos é, sem dúvida, um avanço na tentativa de controlar desenvolvimento e meio ambiente. Acredita-se, todavia, que só um decurso sistemático de antecipação e consideração das conseqüências ambientais das ações governamentais estratégicas, com uma abordagem realmente proativa, é que pode ser capaz de promover formas de desenvolvimento mais sustentáveis.

Essa é uma das principais justificativas utilizadas por aqueles que defendem e promovem a aplicação da AAE. Muitos autores vêem a AAE como uma forma de se alcançar e pôr em prática o conceito de sustentabilidade.

Therivel e Partidário (1996) acreditam que a AAE pode ser uma forma de garantir políticas mais sustentáveis, por intermédio da identificação de parâmetros e referências ambientais e de sustentabilidade, de forma que os objetivos e os possíveis impactos da política em foco estejam de acordo com essas referências.

Dessa forma, o planejamento passa a ser balizado e influenciado por referências e objetivos ambientais, o que pode garantir políticas mais sensíveis à problemática ambiental e, conseqüentemente, mais sustentáveis. Therivel et al. (1992) são da mesma opinião, quando asseguram que os estudos de impacto 
ambiental de projetos são muito pouco eficazes se as decisões estratégicas que deram origem a esses projetos são essencialmente prejudiciais ao meio ambiente, ou são implementadas sem que se leve em consideração os danos que podem causar. A AAE, portanto, pode não só superar as limitações do atual sistema de avaliação de impacto ambiental restrito a projetos, mas será também um passo proativo em direção ao alcance da sustentabilidade.

Dalal-Clayton e Sadler (2005) resumem a necessidade da adoção da AAE, citando seus principais benefícios:

- promove a integração das questões ambientais e de desenvolvimento na tomada de decisão;

- auxilia na construção de políticas e planos ambientalmente sustentáveis;

- fornece oportunidade para consideração de uma série de alternativas muito mais abrangentes do que é normalmente possível na avaliação de projetos;

- leva em consideração, quando possível, os efeitos cumulativos (especificamente pela análise das conseqüências do desenvolvimento em escala regional e setorial) e as mudanças globais;

- melhora a eficiência institucional (especialmente quando a capacidade institucional, os recursos e a qualificação pessoal são limitados), dispensando estudos de impacto ambiental em situações desnecessárias;

- aumenta a influência de alguns ministérios e aumenta a coordenação intersetorial;

- fortalece e confere agilidade à avaliação de impacto de projetos por meio:

- da incorporação de princípios e objetivos ambientais em políticas, planos e programas, que influenciam o desenvolvimento de projetos; 
- da identificação de impactos e da exigência de informações em momentos prévios;

- da exclusão das discussões estratégicas e;

- da redução de tempo e esforços necessários para realização de revisões.

- Além do mais, estabelece mecanismos de participação pública em discussões relevantes para a sustentabilidade em níveis estratégicos.

A participação pública é também um dos princípios essenciais da avaliação ambiental estratégica e espera-se que aumentem a transparência do planejamento de ações estratégicas e o nível de envolvimento de grupos de interesse no debate dessas questões. Na prática, a participação pública ocorre de formas diferentes e em momentos variados da $\mathrm{AAE}$. O fato é que, tradicionalmente, a participação pública em situações estratégicas, quando ocorre, é de forma muito limitada e a AAE pode facilitar a consolidação dessa prática. Therivel (2004) acentua que no mínimo a AAE fornece oportunidade para que o público comente sobre a proposta, antes que ela seja aprovada. No melhor dos casos, a AAE permite que o público possa realmente influenciar de forma ativa a tomada de decisão.

\subsection{Aspectos conceituais}

De maneira simples e geral, a avaliação ambiental estratégica é um instrumento de avaliação de impacto ambiental de ações estratégicas. Essas ações estratégicas, por sua vez, podem se concretizar de diferentes formas (ver quadro 1) e são, geralmente, denominadas de políticas, planos ou programas. 
- Tratados Internacionais

- Políticas Econômicas, Fiscais e Orçamentárias

- Planos Plurianuais de Investimento

- Propostas de Legislação e Regulamentação

- Políticas, Planos e Programas Setoriais (agricultura, transporte, energia, resíduos, turismo etc.)

- Programas Operacionais

- Políticas, Planos e Programas de Desenvolvimento Regional

- Políticas, Planos e Programas de gestão de recursos específicos (gestão costeira, gestão de florestas, recursos hídricos etc.).

Quadro 1. Possíveis ações estratégicas sujeitas à $A A E$

Fonte: Adaptado de Ministério do Meio Ambiente (2002) e Therivel (2004)

Por ser um instrumento de avaliação de situações estratégicas, entender as inter-relações dos diferentes níveis de ação estratégica (políticas, planos e programas), e o papel e função que cada um desempenha, é essencial para compreender a AAE. Como ressaltam Dalal-Clayton e Sadler (2005), porém, essa forma de apresentação da elaboração de políticas, como um processo de diferentes níveis hierárquicos de tomada de decisão, é, na realidade, um pouco mais complexa, pois a formulação de políticas e a tomada de decisão não seguem necessariamente uma seqüência lógica de etapas delimitadas.

Essa inter-relação e suposta seqüência entre políticas, planos, programas e projetos é um modelo teórico que pode, na prática, se configurar de maneira muito distinta. Além disso, estabelecer conceitos e fronteiras entre os diversos níveis e seqüências de ações estratégicas (políticas, planos e programas) pode ser uma 
tarefa difícil, pois essas questões podem significar coisas distintas, dependendo enormemente dos diferentes contextos políticos e institucionais de cada país.

Como defende Frey (2000), no entanto, o fato de os processos políticos reais não corresponderem ao modelo teórico não indica necessariamente que o modelo seja inadequado para a sua explicação. Esse esquema de seqüência e correlação entre níveis hierárquicos fornece um quadro de referência para a análise processual. Assim, ao reconhecer e atribuir funções específicas aos diversos níveis da construção de políticas, obtém-se, mediante a comparação dos procedimentos reais com o modelo teórico, pontos de referência que fornecem pistas para o entendimento do processo.

Na realidade, esse modelo é uma forma de ilustrar e destacar como as ações políticas são concretizadas a partir de conceitos e idéias muito abrangentes (políticas), tomam forma de objetivos mais específicos (planos) e vão se afunilando em programas de ação bem direcionados. Assim, Wood e Djeddour ${ }^{1}$ (1991 apud THERIVEL, 2004, p. 12) definem política como uma orientação, com direções para a ação; um plano como uma série de objetivos coordenados e determinados no tempo, visando à implementação da política; e o programa como um conjunto de projetos.

Essa definição, portanto, sugere uma relação de seqüência entre vários níveis de planejamento e o conceito de avaliação ambiental estratégica segue essa tendência. Assim, acredita-se que a AAE, adotada em todos esses níveis (PPPs), pode poupar tempo e recursos. Isso porque as questões avaliadas nas políticas não precisam ser reavaliadas e rediscutidas nos níveis subseqüentes. Além disso, uma política sujeita à $A A E$ deve influenciar de forma proativa a ação seguinte e

\footnotetext{
${ }^{1}$ WOOD, C.; DJEDDOUR, M. (1991). Strategic environmental assessment: EA of policies, plans and programmes. The Impact Assessment Bulletin, v.10, n.1, p.3-22. Apud THERIVEL, R. (2004). Strategic environmental assessment in action. London: Earthscan.
} 
estabelecer as bases para a elaboração de planos e programas, e, conseqüentemente, projetos também mais sustentáveis e mais sensíveis às questões ambientais.

O quadro 2 ilustra essa hierarquia, tomando como exemplo um sistema de planejamento do turismo, e mostra como a influência da AAE deve permear todos os diferentes níveis de tomada de decisão, por meio de uma avaliação em cascata ${ }^{2}$, desde as ações mais estratégicas, relacionadas à política até os programas mais operacionais, com cada nível de planejamento influenciando a ação subseqüente. Assim, pressupõe-se que cada nível, sujeito à avaliação de impactos, é capaz de influenciar e estabelecer melhores contextos para os níveis seguintes, que são conseqüência e resultado de decisões tomadas anteriormente, em situações mais estratégicas. Esse conceito de seqüência é essencial para entender de que forma a AAE pode influenciar a avaliação de impacto de projetos.

\begin{tabular}{|c|cccc|}
\hline $\begin{array}{c}\text { Relação } \\
\text { entre } \\
\text { ações }\end{array}$ & $\begin{array}{c}\text { Políticas } \\
\text { (AAE) } \\
\text { administrativo }\end{array}$ & $\begin{array}{c}\text { Planos } \\
\text { (AAE) }\end{array}$ & $\begin{array}{c}\text { Programas } \\
\text { (AAE) }\end{array}$ & $\begin{array}{c}\text { Projetos } \\
\text { (EIA) }\end{array}$ \\
\hline \multirow{2}{*}{ Federal } & $\begin{array}{c}\text { Política Nacional } \\
\text { de Turismo }\end{array}$ & $\begin{array}{c}\text { Plano Nacional de } \\
\text { Incentivo ao } \\
\text { Turismo }\end{array}$ & $\begin{array}{c}\text { Programa Nacional } \\
\text { de Roteiros } \\
\text { Turísticos } \\
\text { Integrados }\end{array}$ & $\begin{array}{c}\text { Construção de } \\
\text { Estradas }\end{array}$ \\
\cline { 2 - 6 } Estadual & $\begin{array}{c}\text { Política Estadual } \\
\text { de Turismo }\end{array}$ & $\begin{array}{c}\text { Plano Estadual de } \\
\text { Desenvolvimento } \\
\text { Turístico }\end{array}$ & $\begin{array}{c}\text { Programa de } \\
\text { Incentivo a Projetos } \\
\text { Turísticos }\end{array}$ & $\begin{array}{c}\text { Implantação de } \\
\text { Resort / Hotel } \\
\text { de grande } \\
\text { porte }\end{array}$ \\
\cline { 2 - 6 } Municipal & $\begin{array}{c}\text { Política Municipal } \\
\text { de Turismo }\end{array}$ & $\begin{array}{c}\text { Plano Municipal } \\
\text { de Incentivo ao } \\
\text { Turismo }\end{array}$ & $\begin{array}{c}\text { Programa de } \\
\text { Diversificação da } \\
\text { Oferta Turística }\end{array}$ & $\begin{array}{c}\text { Construção de } \\
\text { Centro de } \\
\text { Feiras e } \\
\text { Eventos }\end{array}$ \\
\hline
\end{tabular}

Quadro 2. A prática da avaliação de impacto em cascata em um sistema de planejamento de turismo Fonte: Adaptado de Dalal-Clayton e Sadler (2005)

\footnotetext{
${ }^{2}$ Em inglês utilizam-se os termos tiering assessment e tiered decision-making.
} 
O conceito de avaliação ambiental estratégica, por sua vez, foi inicialmente constituído tomando como base os princípios e processos até então existentes para avaliação de impactos de projetos, embora fosse reconhecida, desde o início, a necessidade de adaptação dessas metodologias. Assim, as primeiras definições caracterizavam a AAE como uma extensão dos procedimentos de avaliação de projetos em níveis estratégicos (DALAL-CLAYTON e SADLER, 2005).

Essa abordagem concede espaço hoje a outras interpretações. Therivel et al (1992) caracterizaram a AAE como um processo formal, sistemático e detalhado de avaliação dos impactos ambientais de uma política, um plano ou um programa e das suas alternativas, incluindo a preparação de um relatório escrito sobre seus resultados e a utilização desses resultados na tomada de decisão.

Ao adotar os mesmos procedimentos e abordagens da avaliação de impacto de projetos na avaliação ambiental estratégica, porém, é possível que sejam incorporados o mesmos erros recorrentes dos estudos de impacto ambiental, que muitas vezes é visto, como classifica Souza (2000), como um mero processo burocrático, materializando-se num extenso relatório, pouco utilizado na tomada de decisão ou, ainda pior, formulado para justificar decisões já tomadas. Assim, se adotada como um instrumento de avaliação posterior à elaboração da proposta, corre-se o risco de transformar a avaliação ambiental estratégica em um instrumento utilizado de forma a justificar decisões já tomadas. Nesses casos, as questões ambientais não são levadas em consideração no momento da tomada de decisão.

Dalal-Clayton e Sadler (2005) dizem que definições mais recentes trazem abordagens mais amplas, numa perspectiva mais complexa e variada, incluindo dimensões sociais e até econômicas em que a AAE é vista não somente como uma forma de avaliar o impacto de questões estratégicas, mas, principalmente, como 
uma ferramenta de integração das questões ambientais, sociais e econômicas durante a formulação de políticas ${ }^{3}$.

Partidário (1996) lembra que ambas as abordagens são utilizadas, variando de acordo com o sistema de planejamento e avaliação de impactos de cada país, o que determina diferentes sistemas de AAE. A figura 3 representa a relação destes dois modelos de abordagem, que a autora distingue em:

- modelo de abordagem política (top-down approach), fundamentado no sistema de desenvolvimento e avaliação de decisões estratégicas (políticas, planos e programas) e;

- modelo de abordagem de projetos (bottom-up approach), que se apóia nos procedimentos de avaliação de impacto ambiental de projetos.

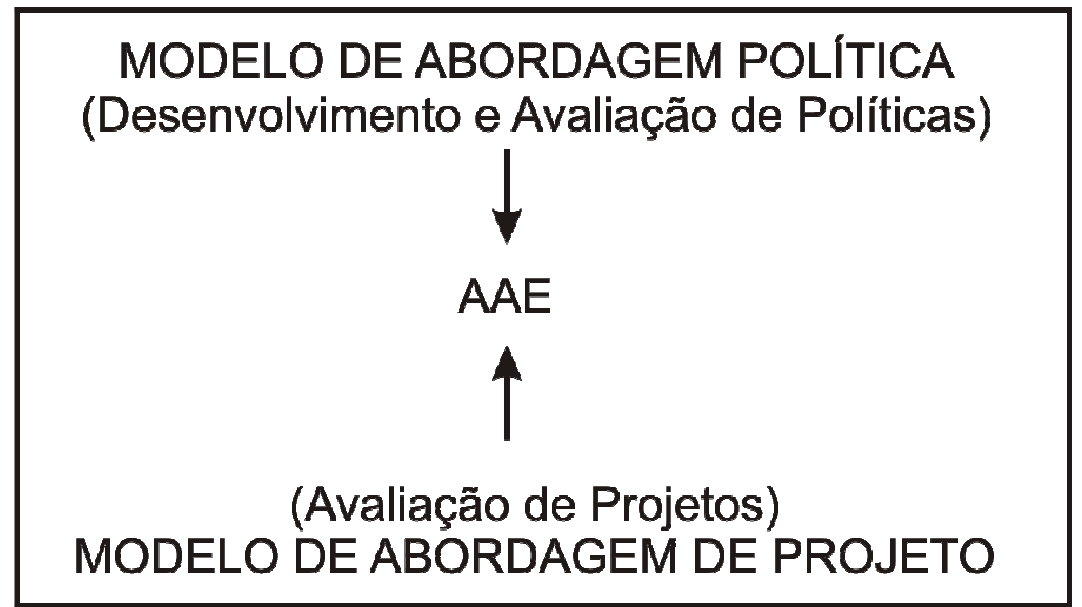

Figura 3. As duas abordagens de AAE

Fonte: Ministério do Meio Ambiente (2002)

\footnotetext{
${ }^{3} \mathrm{O}$ termo política será utilizado de uma forma geral, referindo-se a ações estratégicas (políticas, planos e programas).
} 
No início, quando a $A A E$ ainda era apenas uma idéia e a experiência prática ainda muito incipiente e experimental, era natural que os procedimentos adotados fossem reproduzidos a partir do que já se conhecia, inclusive com certa experiência e maturidade técnica, ou seja, a avaliação de impacto ambiental de projetos. Vários autores, porém, acompanhando a evolução da experiência prática, defendem a AAE como um instrumento que esteja mais integrado às tomadas de decisão e às práticas de formulação de política e de planejamento. As definições a seguir comprovam essa posição.

Partidário (2000) ressalta que a avaliação ambiental estratégica deve ser moldada de forma que seja claramente direcionada em favor da tomada de decisão sustentável. A autora, portanto, defende a AAE como um instrumento adaptado para ser integrado ao processo de tomada de decisão existente, ou seja, um instrumento de auxílio à decisão, e que possa trazer à pauta questões relacionadas à busca pela sustentabilidade.

Brown e Therivel (2000) apontam que metodologias de AAE devem dar ênfase ao papel desse instrumento como uma ferramenta de formulação de ações estratégicas, pois é no estágio da elaboração de políticas, planos e programas, e não na avaliação de uma política já elaborada, que a AAE pode ser mais eficaz. Os autores, portanto, reafirmam o papel da AAE como ferramenta de auxílio na formulação de políticas mais sustentáveis, num estágio que permita que a $\mathrm{AAE}$ possa contribuir para a construção dessas políticas e não um instrumento de avaliação de decisões já tomadas. Do contrário, corre-se o risco de a AAE ser utilizada como uma mera etapa de aprovação ou rejeição de propostas.

Dalal-Clayton e Sadler (2005) consideram que a AAE é uma ferramenta de auxílio à tomada de decisão e não a tomada de decisão em si. Os autores chamam 
a atenção para a necessidade de adaptar a AAE ao ciclo de planejamento das políticas, sem que ela se transforme no próprio processo de decisão, ou seja, numa etapa de aprovação ou rejeição de políticas, planos e programas.

Os autores, portanto, são unânimes ao defender a AAE como um instrumento de apoio à tomada de decisão, e não a decisão em si, ou seja, a AAE deve oferecer cenários e informações que possam embasar a elaboração de políticas.

Além disso, a AAE não pode ser interpretada somente como extensão dos já conhecidos estudos de impacto ambiental de projetos para situações mais estratégicas, mas como um processo com vistas à promoção e elaboração de políticas mais sustentáveis e abordagens mais pró ativas em favor do meio ambiente e do bem-estar social em que a questão ambiental é realmente inserida no jogo da tomada de decisão política, juntamente com as preocupações sociais e econômicas. Até porque, em essência, a lógica da elaboração de políticas difere consideravelmente da concepção de projetos e empreendimentos seja pela característica e quantidade dos agentes envolvidos, pelo alcance e abrangência de seus efeitos, pela quantidade de fatores econômicos, ambientais e sociais em questão, como por ser um procedimento essencialmente político e, por isso, muito mais complexo.

Existe evidência empírica de que os órgãos governamentais também preferem essa abordagem. Bailey e Renton ${ }^{4}$ (1997, apud BROWN e THERIVEL, 2000, p. 186), em pesquisa junto a órgãos governamentais na Austrália, relataram uma clara rejeição por parte desses órgãos pela avaliação de impacto ambiental de políticas, seguindo os modelos dos tradicionais EIAs de projetos. Eles se mostraram,

\footnotetext{
${ }^{4}$ BAILEY, J.; RENTON, S. (1997). Redesigning EIA to fit the future: SEA and the policy process. Impact assessment, v.15, p.379-334. Apud BROWN, A.L.; THERIVEL, R. (2000). Principles to guide the development of SEA methodology. Impact Assessment and Project Appraisal, Surrey, v.18, n.3, p.183-189, Apr.
} 
no entanto, dispostos a integrar questões ambientais dentro dos procedimentos de formulação de políticas, mas não como uma simples extensão dos conhecidos estudos de impacto ambiental para níveis mais estratégicos.

Brown e Therivel (2000), seguindo essa tendência, definem AAE como um processo realizado para fornecer aos propositores e também responsáveis pelas decisões (durante a formulação da política) uma compreensão holística das implicações ambientais e sociais da proposta, expandindo o foco da política. A política, portanto, é desenvolvida com base num conjunto muito maior de perspectivas, objetivos e restrições. Essas questões incluem considerações que, sem a AAE, só surgiriam no momento do EIA para projetos como impactos ecológicos, geração de resíduos, contribuição para aumento da poluição além das questões referentes ao desenvolvimento sustentável, como o princípio da precaução, a participação da população, o uso sustentável dos recursos etc. Uma representação simplificada desse conceito é ilustrada na figura 4.

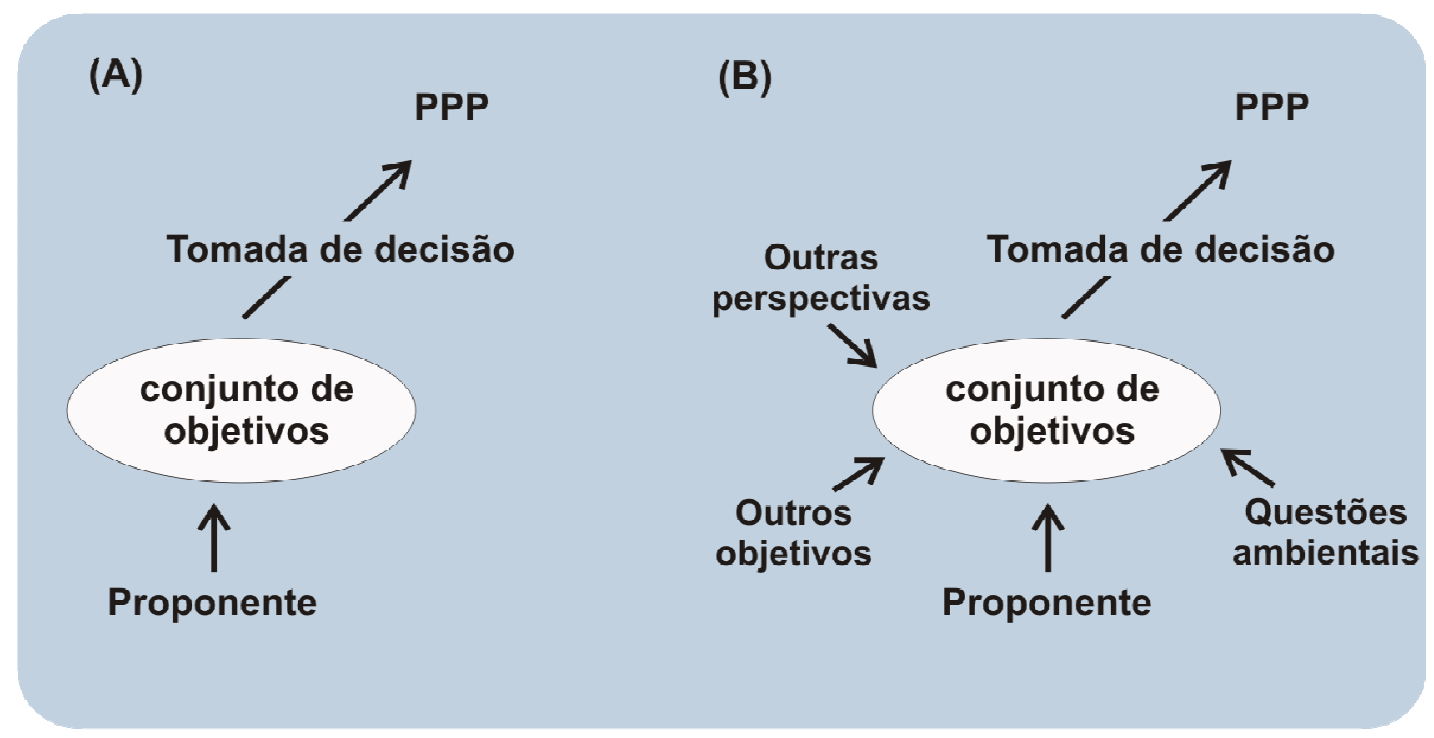

Figura 4. Um modelo conceitual simplificado de constituição de uma política sem (A) e com (B) a Avaliação Ambiental Estratégica Fonte: Adaptado de Brown e Therivel (2000) 
Apesar de definições mais recentes apresentarem a AAE de um modo mais amplo, um instrumento integrado ao planejamento, na prática diversas abordagens ainda podem ser identificadas. Therivel e Partidário (1996) resumem esses diferentes modelos de aplicação da AAE em:

- modelos próximos dos estudos de impacto ambiental de projetos, em que, essencialmente, a AAE se ajusta ao processo já existente de tomada de decisão, incluindo um estágio da avaliação de impacto propriamente dita e a tomada de decisão;

- modelos integrados em que a formulação de PPPs é sujeita a diversos estágios de tomada de decisão (escolha de objetivos, análise de alternativas, estabelecimento de medidas mitigadoras etc.), integrando a avaliação ambiental estratégica a cada etapa de decisão;

- o modelo integrado pode eventualmente evoluir para um modelo centrado no estabelecimento de objetivos. Esse deve tentar ajustar a construção de PPPs a um processo mais estratégico, transparente e baseado em objetivos e referências de sustentabilidade, que devem influenciar todos os níveis de políticas, planos e programas.

Essa diversidade de abordagens e modelos de AAE ocasiona o uso de ampla quantidade de termos. Apesar de ser uma denominação corrente, já amplamente utilizada e difundida pela comunidade científica, a expressão avaliação ambiental estratégica é apenas uma das formas utilizadas para designar a avaliação de impacto de ações estratégicas. As diferentes abordagens e contextos políticos e 
institucionais também influenciam o fato de haver tantas diferentes nomenclaturas. Algumas delas são relacionadas no quadro 3 a seguir. 
- Avaliação Ambiental Estratégica (SEA) - termo geral utilizado para designar a avaliação de impacto de políticas, planos e programas;

- Avaliação de Impacto de Políticas ou Avaliação de Políticas (Policy Impact Assessment ou Policy Appraisal) - termos adotados para particularizar a avaliação de impacto ambiental de políticas;

- Teste Ambiental (Environmental E-test) - utilizado na Holanda para avaliação de propostas de legislação, com procedimentos específicos de listagens e critérios de sustentabilidade;

- Avaliação Ambiental Regional (Regional EA) - estabelecida pelo Banco Mundial para avaliações de âmbito regional de propostas de desenvolvimento multi-setorial, numa dada área geográfica e durante um período determinado;

- Avaliação Ambiental Estratégica Analítica (ANSEA) - um sistema de avaliação de processos de tomada de decisão, desenvolvido por um conjunto de instituições européias para auxiliar na implementação da Diretiva Européia;

- Avaliação Ambiental Setorial (Sectoral EA) - estabelecida pelo Banco Mundial para avaliação de políticas e programas setoriais, envolvendo sub-projetos múltiplos;

- Supervisão Ambiental (Environmental Overview) - adotada pelo Programa das Nações Unidas para o Desenvolvimento (PNUD) no processo de formulação de programas, identificação de oportunidades, impactos ambientais e sociais e medidas mitigadoras na revisão de programas;

- Análise Ambiental Estratégica (Strategic Environmental Analysis) - abordagem utilizada pela Agência Internacional de Financiamento da Holanda para a avaliação de planos e programas;

- Avaliação de Impacto Ambiental Estratégica (Strategic Environmental Impact Assessment) - termo utilizado na Holanda para a avaliação de planos e programas, seguindo-se os mesmos procedimentos da avaliação de impacto ambiental de projetos;

- Avaliação Ambiental Programática (Programmatic Environmental Assessment) tipo estabelecido nos Estados Unidos para a avaliação de grupos de projetos referidos a uma mesma área geográfica ou que guardam similaridades em termos de tecnologia e tipologia;

- Análise Ambiental do País (Country Environmental Analysis) - adotado pelo Banco Mundial para avaliar as prioridades ambientais de desenvolvimento e as implicações ambientais de políticas;

- Avaliação de Sustentabilidade (Sustainable Appraisal) - termo genérico para abordagens de avaliações baseadas na integração das dimensões ambientais, sociais e econômicas de PPPs.

Quadro 3. Exemplos de termos utilizados para designar diferentes tipos de avaliações ambientais estratégicas

Fonte: Dalal-Clayton e Sadler (2005) e Ministério do Meio Ambiente (2002) 
Além disso, a experiência e a pesquisa em avaliação ambiental estratégica ainda são relativamente recentes e tanto os conceitos como a prática se apresentam de várias formas, fazendo com que o consenso em torno do que pode ser considerado AAE ainda seja alvo de debates e divergências. Por isso, Dalal-Clayton e Sadler (2005) defendem a necessidade de se utilizar definições amplas e flexíveis, capazes de abranger essa ampla gama de diferentes abordagens de AAE. No sentido de entender a evolução da experiência prática os autores distinguem três categorias de AAE:

- procedimentos formais de AAE como aqueles prescritos em instrumentos internacionais ou supranacionais (Protocolo relativo à $A A E$ e Diretiva Européia - 2001/42/EC ${ }^{5}$ ) ou mediante instrumentos legais e políticos estabelecidos por alguns países ou instituições internacionais, como o Banco Mundial;

- outros processos semelhantes de avaliação ambiental de PPPs e projetos de lei e;

- grande número de processos, métodos e aplicações que se aproximam do conceito de AAE, designados pelos autores de 'para-SEA', expressão que se refere a abordagens que não se enquadram em especificações formais ou definições de $A A E$, mas possuem o mesmo propósito e algumas de suas características ou elementos.

Apesar da necessidade e importância de se chegar a um consenso quanto a uma definição ampla o suficiente que possa levar em consideração as diferentes

\footnotetext{
${ }^{5}$ Ver mais sobre Protocolo relativo à AAE e Diretiva Européia na página 53.
} 
realidades institucionais e a experiência prática no mundo, resta ainda a necessidade, não menos importante, de se precisar o que, na experiência prática mundial, realmente pode ser considerado AAE, para não correr o risco de transformar esse instrumento num conceito vago e impreciso, perdendo assim seu sentido fundamental e seus princípios. Therivel e Partidário (1996), na tentativa de impor um limite, chamam a atenção para a importância de diferenciar a AAE de algumas práticas correntes. A AAE, portanto, não é:

- estudos de impacto ambiental de megaprojetos, pois estes geralmente estão relacionados a escolhas locacionais, envolvem uma única atividade e, portanto, não são estratégicos. É o caso de grandes projetos de rodovias, infra-estrutura, complexos de lazer e turísticos, realizados de forma independente ou dentro de um projeto de grande escala que integre várias ações e empreendimentos;

- PPPs integrados, ou seja, aqueles que incorporam questões ambientais, geralmente um tópico ou um capítulo da política, mas não implicam um processo formal de análise de alternativas baseando a tomada de decisão em critérios ambientais;

- auditorias ambientais ou relatórios de diagnóstico ambiental, que não prevêem futuros impactos ambientais resultantes da aplicação de uma política;

- estudos de AAE, que não influenciam a tomada de decisão;

- avaliações, estratégias ambientais ou análises de custo-benefício que não prevêem as futuras conseqüências de PPPs, não consideram alternativas e/ou não resultam em um relatório escrito e; 
- planos de gestão integrados, que analisam impactos ambientais em uma determinada região, mas não informam alternativas de planejamento e de desenvolvimento.

A experiência prática e a produção científica a respeito da AAE crescem, o que contribui para o aperfeiçoamento técnico e a consolidação conceitual desse instrumento. Pode-se afirmar, entretanto, que, embora princípios e diretrizes pareçam ter alcançado certo consenso entre pesquisadores e profissionais, na prática a AAE ainda apresenta diversas formas e abordagens. No presente trabalho, defende-se a necessidade de reflexão a respeito de um modelo de avaliação ambiental estratégica que seja adaptado à realidade brasileira, mas que não deixe de considerar alguns princípios básicos que devem acompanhar a aplicação desse instrumento em qualquer situação. A AAE, portanto, deve garantir que as questões ambientais sejam levadas em consideração na concepção de ações estratégicas, e não se resuma a aprovação ou rejeição de propostas de políticas. Dessa forma, a AAE deve ser um instrumento com o objetivo de alcançar a sustentabilidade.

\subsection{Experiências e aplicação da AAE no mundo}

As reflexões teóricas apresentadas anteriormente são acompanhadas por uma rápida e crescente evolução na experiência internacional, não só em países desenvolvidos e/ou onde requisitos legais prevêem a adoção da AAE. Cada vez mais países em desenvolvimento também realizam alguma forma de avaliação de suas ações estratégicas, seja de forma voluntária, seja como requisito para ações de investimentos de agências e instituições multilaterais de desenvolvimento. 
Sadler (2001) identificou três fases do desenvolvimento e aplicação da AAE. A primeira delas foi a fase de desenvolvimento (1970-1989), quando os primeiros países estabeleceram alguns precedentes legais e políticos para o surgimento da AAE, em especial os estudos de impacto ambiental para projetos. Somente os Estados Unidos previam avaliações de certos planos e programas governamentais. No final dos anos 1980, outros países e organizações internacionais começaram a desenvolver experiências de AAE.

Durante a década de 1990 (fase de formalização), um número crescente de países desenvolveu sistemas de AAE, principalmente mediante leis ou requerimentos próprios ou por meio da incorporação da AAE em leis da AIA de projetos.

A partir de 2001 até os dias atuais, na chamada fase de ampliação, a AAE parece estar em crescente consolidação, como resultado do desenvolvimento de leis e políticas internacionais. Além disso, as agências multilaterais de desenvolvimento introduziram algumas formas de avaliação setoriais e regionais que se aproximam do conceito de AAE. Juntos, segundo o autor, esses instrumentos podem triplicar, até a próxima década, o número de países com providências para a adoção da AAE.

Muitos dos países com experiência em AAE já possuem inclusive requerimentos legais que exigem ou estimulam a sua adoção. No final do ano de 2003, cerca de 20 países já tinham estabelecido exigências legais ou guias para sua implementação (THERIVEL, 2004). O quadro a seguir faz referência a alguns desses dispositivos adotados em vários países. 


\begin{tabular}{|c|c|}
\hline País / Organização & Dispositivos \\
\hline Austrália & Environment Protection and Biodiversity Act (1999). \\
\hline Canadá & Cabinet Directive 1990 (emenda de 1999). \\
\hline Dinamarca & $\begin{array}{l}\text { Prime Minister's Office circular (1993, emendas de } \\
1995 \text { e 1998). }\end{array}$ \\
\hline Finlândia & $\begin{array}{l}\text { Act on Environmental Impact Assessment } \\
\text { Procedure (1994) e Guidelines on ElA of Legislative } \\
\text { Proposals (1998). }\end{array}$ \\
\hline Holanda & $\begin{array}{l}\text { Environmental Impact Assessment Decree (1987, } \\
\text { emenda de 1994) e Cabinet Order (1995). }\end{array}$ \\
\hline Nova Zelândia & $\begin{array}{l}\text { Resource Management Act (1991, com várias } \\
\text { emendas). }\end{array}$ \\
\hline Reino Unido & $\begin{array}{l}\text { Better Policy Making: A Guide to Regulatory Impact } \\
\text { Assessment (2003). } \\
\text { The Environmental Assessment of Plans and } \\
\text { Programmes Regulations } 2004 \text { (somente para } \\
\text { Inglaterra). } \\
\text { Strategic Environmental Assessment: Guidance for } \\
\text { Planning Authorities (2003). }\end{array}$ \\
\hline Estados Unidos & $\begin{array}{l}\begin{array}{l}\text { National Environmental Policy } \\
\text { Regulations (1978) }\end{array} \\
\end{array}$ \\
\hline União Européia & $\begin{array}{l}\text { Diretiva do Parlamento Europeu (2001/42/CE) } \\
\text { relativa à avaliação dos efeitos de determinados } \\
\text { planos e programas no ambiente. }\end{array}$ \\
\hline $\begin{array}{l}\text { Comissão Econômica das Nações } \\
\text { Unidas para a Europa (UNECE) }\end{array}$ & $\begin{array}{l}\text { Protocolo Relativo à Avaliação Ambiental } \\
\text { Estratégica (2003). }\end{array}$ \\
\hline
\end{tabular}

Quadro 4. Dispositivos institucionais para adoção da AAE em alguns países

Fonte: Dalal-Clayton e Sadler (2005)

Dentre esses requerimentos legais, destaca-se aqui a Diretiva Européia 2001/42/CE, que estabelece requisitos para avaliação dos efeitos no ambiente de determinados planos e programas dos países membros da União Européia e o Protocolo relativo à $\mathrm{AAE}$, elaborado no âmbito da Comissão Econômica para a Europa (UNECE), que também estabelece disposições para garantir as considerações ambientais na tomada de decisão relacionada a políticas e legislações.

Alguns países europeus estabeleceram inicialmente requerimentos para aplicação de avaliações ambientais estratégicas a partir dos anos de 1980 (THERIVEL, 2004), mas foi só em julho de 2001 que os países membros da União 
Européia aprovaram uma Diretiva (2001/42/EC) que estabelecia princípios gerais para um sistema de avaliação ambiental de planos e programas capazes de ter efeitos significativos sobre o meio ambiente. A Diretiva entrou em vigor três anos depois, em julho de 2004, e deixou a cargo dos Estados-membros o estabelecimento de especificidades processuais próprias, o que estimulou o surgimento de diversos guias, decretos e outros dispositivos legais por todos os países da União Européia.

Um pouco mais recente, o Protocolo relativo à $A A E$ foi desenvolvido por um grupo de trabalho das Nações Unidas, finalizado em janeiro de 2003 e formalmente aprovado por 35 países membros da UNECE em maio de 2003. Apesar de ter sido desenvolvido e negociado pelos países membros da UNECE, o Protocolo está aberto para adesão de todos os países membros das Nações Unidas (THERIVEL, 2004).

Ambos os instrumentos se aplicam a uma grande variedade de ações estratégicas, são adotados em vários países e representam o esforço de um conjunto de Estados em torno da criação de um sistema comum de AAE. Therivel (2004) assinala que, para os próximos anos, devem surgir ainda mais regulamentos, dispositivos administrativos, documentos-guias, desenvolvidos por diversos países, como conseqüência da entrada em vigor da Diretiva e do Protocolo. No Reino Unido a Diretiva já foi regulamentada. Inglaterra, País de Gales, Escócia e Irlanda do Norte já possuem, cada um, regulamentações específicas que apontam as autoridades ambientais que devem ser consultadas e estabelecem formas de consulta pública, além de terem desenvolvido vários guias práticos (a autora cita a existência de 11 desses guias) que auxiliam na adoção do modelo de avaliação da Diretiva. 
Um estudo realizado na Grã-Bretanha, há quase uma década, já mostrava que aproximadamente três quartos das autoridades locais já haviam iniciado algum tipo de avaliação ambiental de suas ações e propostas de desenvolvimento. Mais recentemente, uma pesquisa realizada após a entrada em vigor da Diretiva Européia mostrou que as autoridades locais no Reino Unido já haviam iniciado aproximadamente 400 a 450 avaliações ambientais estratégicas, das quais 40 a 45 já haviam sido completadas. (THERIVEL, 1998; THERIVEL e WALSH, 2006).

Na relação de países que já realizam de alguma forma avaliações ambientais estratégicas, destacam-se, além dos Estados Unidos, Canadá, Austrália e Nova Zelândia, os países da União Européia, principalmente Reino Unido, Dinamarca e Holanda (CHAKER et al., 2006; WARD et al., 2005; WILBURN, 2005).

Além disso, alguns países do Leste Europeu, ex-repúblicas socialistas com forte tradição em planejamento - especialmente República Tcheca, Bulgária, Estônia, Polônia e Eslováquia - incentivados pela preparação para adesão à União Européia, também já possuem experiências em avaliações ambientais de planos e programas (CHAKER et al., 2006; DUSIK, SADLER e MIKULIC, 2001; SMUTNY et al., 2005).

Embora a maioria dos países em desenvolvimento não possua requerimentos legislativos ou administrativos para a adoção da $A A E$, muitos têm experiências nesse campo. Isso é resultado, principalmente, a exemplo do que aconteceu com a AlA de projetos, de requisitos e condicionantes de investimentos dos países desenvolvidos e das agências e instituições multilaterais, como o Banco Mundial.

Assim, um crescente número de países em desenvolvimento está ganhando experiência em $\mathrm{AAE}$, em conseqüência das avaliações regionais e setoriais estabelecidas pelo Banco Mundial. Dalal-Clayton e Sadler (2005), porém, chamam a 
atenção para o perigo de a $A A E$ ser adotada rápida e inquestionavelmente, sem experimentação e adaptação às necessidades locais dos países em desenvolvimento, e sem consideração a respeito do que realmente pode vir a funcionar institucionalmente nesses países. Os autores acreditam que é preciso cautela ao analisar e caracterizar essas experiências como AAE propriamente ditas e utilizam o termo Para-SEA para designar experiências que não se adequam ao conceito formal de $A A E$ ou às especificações contidas em lei, mas que têm algumas de suas características.

Os mesmos autores afirmam que, mesmo nos países com maior experiência, deve demandar tempo para que estes procedimentos de AAE sejam totalmente implementados, e mais tempo ainda, até que a qualidade da prática e sua contribuição para o processo decisório cheguem a um padrão coerente.

No Brasil, nota-se crescente interesse, tanto no âmbito governamental quanto acadêmico, no que se refere à aplicação da AAE no Território nacional.

Desde 2001, a UNIVERSIDADE FEDERAL DO RIO DE JANEIRO, através da Coordenação dos Programas de Pós-Graduação de Engenharia e do Laboratório Interdisciplinar de Meio Ambiente - UFRJ/COPPE/LIMA, realiza estudos e parcerias, com o Ministério do Meio Ambiente (MMA), relacionados à viabilidade de adoção da AAE no Brasil, com especial ênfase para o setor energético (UFRJ/COPPE/LIMA, 2006).

Além disso, o próprio MMA realizou recentemente dois encontros - "Diálogo Técnico sobre Avaliação Ambiental Estratégica e Planejamento no Brasil" e "Seminário Latino Americano de Avaliação Ambiental Estratégica" - a fim de estimular a discussão em torno de elementos conceituais, tendências internacionais e perspectivas para aplicação da AAE no Brasil (MINISTÉRIO DO MEIO AMBIENTE, 
2006). A experiência e a pesquisa, porém, ainda são incipientes e o País ainda carece de mais discussão, estudos e reflexões sobre adoção desse instrumento na realidade brasileira.

\subsection{Metodologias e formas de aplicação}

Já se chamou a atenção aqui para o imperativo de se utilizar a AAE como um instrumento de auxílio na construção de PPPs mais sustentáveis. Dessa forma, a AAE deve acompanhar a formulação dessas políticas e ser capaz de se moldar a esses procedimentos. Para tanto, diversas metodologias (abordagens e técnicas) são utilizadas na prática da avaliação ambiental estratégica. Apesar de muitos procedimentos ainda se assemelharem àqueles adotados na avaliação de impacto ambiental de projetos, a AAE toma forma diferenciada, geralmente integrada e adaptada aos processos de decisão e às práticas de formulação de política e de planejamento.

A necessidade de se fazer desse instrumento um elemento intrínseco da elaboração da política faz com que cada ambiente político e organizacional tenha que, necessariamente, desenvolver os mecanismos administrativos e institucionais necessários à realização da AAE (PARTIDÁRIO, 1996).

Brown e Therivel (2000) também compartilham a mesma opinião, ao defenderem a posição de que as metodologias, técnicas, processos, o tempo de execução e as condições utilizadas na AAE devem ser moldados de acordo com o contexto de elaboração da política e da tomada de decisão. A AAE é aplicável a vários níveis de ações estratégicas e a diferentes organizações de planejamento, e 
essa diversidade de situações dificulta a existência de uma só forma e metodologia de AAE que seja aplicável uniformemente.

Os autores citam alguns fatores que devem influenciar o caráter das metodologias adotadas:

- os diferentes órgãos e organizações envolvidos na elaboração de políticas, as diferentes culturas organizacionais e suas diversas formas de agir e de tomar decisões;

- o nível em que ocorrem a formulação da política e a tomada de decisão (internacional, nacional, regional ou local), visto que os objetivos e as questões avaliadas nesses diferentes níveis diferem bastante;

- o tempo de execução e as informações disponíveis para a avaliação;

- o grau de abertura das instituições e de envolvimento da sociedade na formulação de políticas;

- a origem dos recursos financeiros utilizados na AAE (públicos ou privados);

- a complexidade das questões a serem analisadas (PPPs setoriais, multissetoriais, etc.) e;

- o momento de realização da AAE.

Qualquer tentativa, portanto, de imposição da $A A E$ no planejamento não obterá sucesso sem que se reconheça o processo de formulação e tomada de decisão na realidade em questão. Por isso, é preciso pesquisa nessa área, buscando formas de inserir a AAE, adaptando metodologias e técnicas, em diferentes ambientes políticos e organizacionais (BROWN E THERIVEL, 2000). Do contrário, a AAE poderia tornar o planejamento lento e burocrático, interpondo 
obstáculos à formulação dessas políticas. Por isso, é importante destacar que os procedimentos de AAE não estão relacionados à aprovação ou rejeição, mas de formulação de propostas.

A revisão da experiência internacional permite também perceber que são diferentes os processos de avaliação dos impactos de uma política, um plano e um programa (MMA, 2002, p. 22).

- política - requer abordagens mais rápidas e flexíveis, ajustadas à natureza incremental dos respectivos processos (muitas vezes quase informais);

- plano - para ser eficaz, é necessário o ajuste dos procedimentos de AAE aos procedimentos de planejamento, garantindo que, em cada momento de decisão, sejam consideradas opções alternativas e apurados os seus efeitos, re-introduzindo no processo de planejamento o produto da avaliação e;

- programa - desde que se entenda um programa como o escalonamento temporal de investimentos e o cronograma de atividades que se implementarão por meio de projetos de desenvolvimento, a avaliação ambiental pode ser tratada como uma abordagem muito próxima da avaliação de impacto ambiental de projetos.

$\mathrm{Na}$ realidade, a prática atual evidencia que não existe apenas uma forma de realizar avaliações ambientais estratégicas. De fato, a AAE deve ser vista como um conjunto de ferramentas. Assim, ela pode tomar várias formas e ser designada por diferentes termos (PARTIDÁRIO, 2000).

O crescente número de experiências e os estudos que se seguem, no entanto, levam pesquisadores a identificar e analisar os elementos centrais que 
condicionam boas experiências de AAE. Assim, buscou-se aqui evidenciar os fatores que, segundo os autores pesquisados, podem assegurar, ou pelo menos aumentar, as possibilidades de experiências bem-sucedidas de AAE, ou seja, situações em que questões ambientais tenham sido realmente consideradas e incorporadas na elaboração de ações estratégicas.

Uma análise da bibliografia e de estudos de caso permitiu destacar fatores e situações decisivos, quando se trata de melhores práticas do processo de AAE. Os principais fatores de consenso, baseados em Dalal-Clayton e Sadler (2005); Partidário (1996); Sadler (2001) e Therivel (1998, 2004), são:

\section{- O momento de realização da AAE}

A experiência internacional evidencia que, quanto mais cedo se dá início à avaliação, maiores são as possibilidades de influência decisiva das questões ambientais no estabelecimento das políticas. A AAE, portanto, não pode ser um instrumento de avaliação posterior à elaboração da política, mas deve condicionar e influenciar a sua elaboração.

\section{- Os requisitos e referências de sustentabilidade}

Isso pode se traduzir em objetivos, parâmetros, indicadores, metas, capacidade de suporte ou políticas de sustentabilidade. As referências é que devem balizar a construção das políticas e devem ser incorporadas às questões estratégicas.

\section{- Envolvimento do público e dos tomadores de decisão}

O momento e as formas de participação variam bastante, mas os grupos de interesse devem ser informados e envolvidos e suas observações levadas em consideração. A participação dos tomadores de decisão pode ser decisiva para 
garantir que os resultados da AAE sejam realmente considerados e que isso resulte em políticas mais sustentáveis.

\section{- Consideração de alternativas:}

A análise de alternativas garante que questões ambientais determinem a formulação de políticas desde o seu estágio inicial, quando decisões importantes ainda não foram tomadas. Essa abordagem resulta em ações estratégicas mais proativas.

\section{- Integração horizontal}

Levar em consideração outras políticas, planos e programas relacionados. Nesse caso, é essencial a integração interinstitucional.

\section{- Integração vertical}

Garantir que a AAE esteja presente em todos os níveis de planejamento (políticas, planos e programas) e nos demais âmbitos da Administração Pública (federal, estadual e municipal), com cada nível influenciando a ação subseqüente, reduzindo sua abrangência e escopo e aumentando o grau de detalhamento das informações necessárias.

\section{- Integração metodológica}

É essencial que a AAE leve em consideração as abordagens já utilizadas no planejamento local (etapas, canais e formas de participação, informações disponíveis etc.). Além disso, deve-se considerar a existência de outros instrumentos de gestão ambiental já adotados e de que forma a AAE se relaciona com eles.

\section{- Transparência e flexibilidade}

Abertura, transparência trazem mais credibilidade e facilitam a participação pública proativa, assim como estruturas políticas e institucionais abertas e flexíveis. 
Deve ficar claro de que maneira as questões ambientais influenciaram as decisões e a elaboração da política.

\section{- Monitoramento}

Um sistema de monitoramento é essencial para garantir a retroalimentação do processo na medida em que fornece informações para mudanças na ação em questão ou para intervenções futuras, auxilia na identificação dos impactos que realmente ocorreram com a implementação da proposta e pode ser útil para avaliar se as medidas mitigadoras propostas estão sendo adotadas.

Assim, apesar da necessidade de se flexibilizar formas e procedimentos de AAE de acordo com os diferentes contextos, a maioria dos autores concorda com a idéia de que a $A A E$ deve obedecer a alguns princípios e etapas fundamentais. Freqüentemente a $\mathrm{AAE}$ é apresentada como uma seqüência de etapas, que normalmente são adaptadas ao planejamento existente, e elas serão aqui analisadas individualmente, apesar de, na prática, se apresentarem de forma extremamente interligadas.

Com vistas a tornar o conceito de AAE mais operacional, Therivel et al. (1992) sugerem uma seqüência de passos a serem seguidos, visando a um objetivo final, que é o da sustentabilidade; conforme é mostrado a seguir.

- Comprometimento com o objetivo da sustentabilidade;

- determinação de parâmetros mediante os quais a sustentabilidade deve ser alcançada;

- determinação da capacidade de suporte;

- avaliação ambiental estratégica de políticas, planos e programas; 
- avaliação de impacto ambiental de projetos;

- monitoramento.

Segundo os autores, esses passos ajustam as exigências teóricas da sustentabilidade em um contexto prático e estabelecem uma situação favorável para a realização de estudos de impacto ambiental de projetos.

Numa abordagem ainda mais prática, Therivel (2004) estabelece um esquema de etapas do processo de AAE (ver Figura 5), baseado nos requisitos da Diretiva Européia, e fazendo referência direta à tomada de decisão. É preciso destacar o fato de que a Diretiva Européia se aplica somente a planos e programas e não abrange a avaliação de políticas. 
Tomada de decisão estratégica

Identificar objetivo da ação estratégica alcançar o objetivo da açāo estratégica e resolver problemas

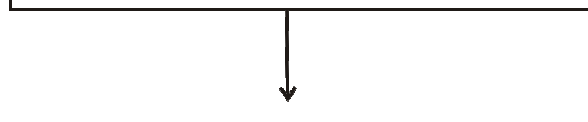

Escolher melhor (es) alternativa (s); detalhar a estratégia (instruções)

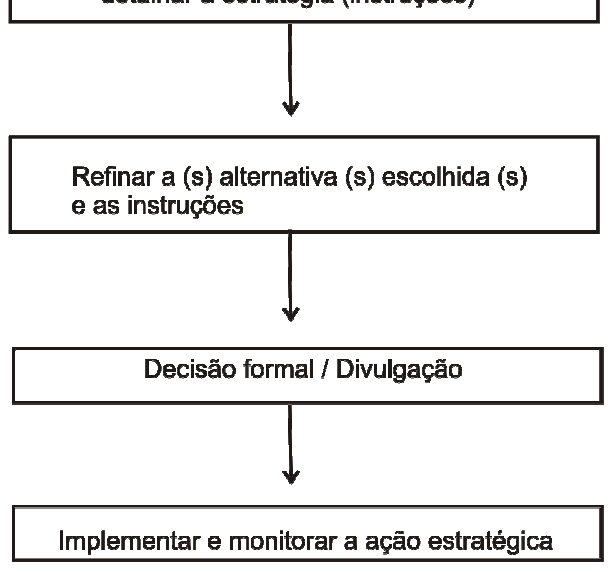

AAE: input de questóes ambientais

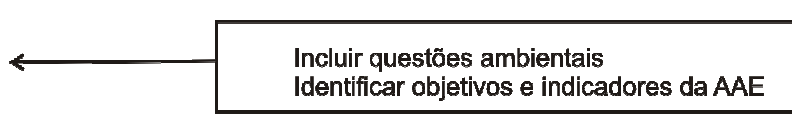

Descrever a base ambiental e identificar os problemas ambientais locais

Identificar links com outras ações estratégicas
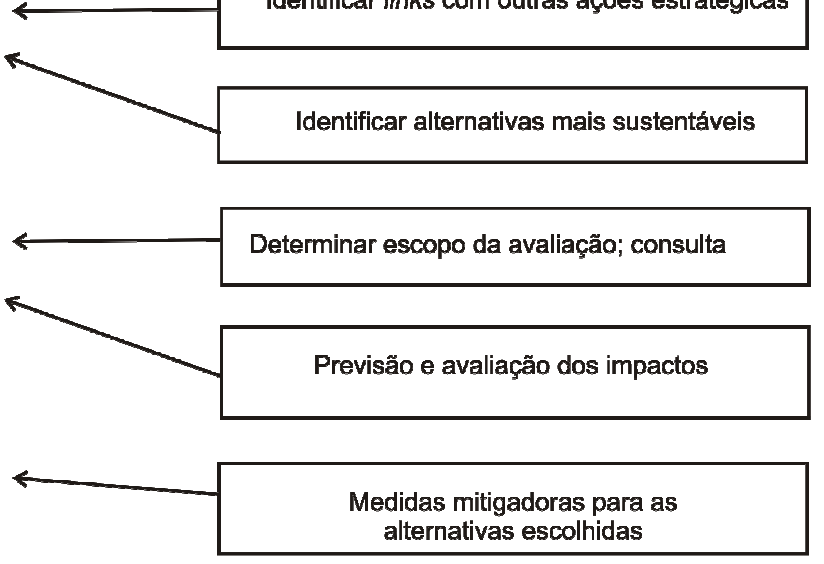

Elaborar Relatório de AAE; estabelecer diretrizes para implementação

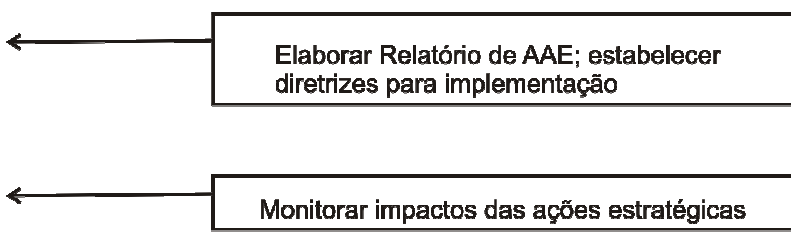

Figura 5. Etapas do processo de AAE Fonte: Adaptado de: Therivel (2004)

Therivel e Partidário (1996) também chamam a atenção para o fato de que nem toda AAE irá necessariamente compreender todas essas etapas, nem apresentá-las com o mesmo grau de detalhamento. A seguir cada etapa é analisada de modo mais detalhado.

\subsubsection{Objetivos e indicadores}

É preciso, inicialmente, que se faça a distinção entre os objetivos da ação estratégica (PPP) e os da AAE. Os objetivos da política são aqueles que devem ser 
alcançados mediante a própria implementação da política. Os objetivos da AAE também chamados de objetivos ambientais ou de sustentabilidade, dependendo do foco da AAE em questão - são abrangentes e estratégicos para os quais a política deve contribuir, ou seja, são úteis para dar certa dimensão prática do conceito de sustentabilidade na medida em que representam situações pretendidas de proteção ambiental.

Associados a esses objetivos, estão os indicadores e, quando possível ou pertinente, as metas. Os objetivos descrevem uma situação pretendida, como, por exemplo, "reduzir a poluição do ar" ou "melhorar a saúde humana". Os indicadores são medidas variáveis no tempo e, relacionados aos objetivos, indicam o seu alcance ou não. Por exemplo, os "níveis de $\mathrm{CO}_{2}$ emitidos em determinada região". As metas representam situações ideais a serem buscadas, geralmente por intermédio de números ou percentuais. Por exemplo, "reduzir a emissão de $\mathrm{CO}_{2}$ em $X \% "$

O levantamento de objetivos e indicadores é uma etapa central da AAE e deve influenciar praticamente todas as demais fases da avaliação. A figura 6 explica de que forma acontece essa relação. Os objetivos e indicadores são a referência para a coleta de informações da base ambiental. Os indicadores descrevem a base e permitem que o estudo não se perca numa enorme quantidade de dados desnecessários, mantendo o foco nas questões ambientais que realmente interessam para a ação estratégica em questão. Por outro lado, com o levantamento de informações da base ambiental e a identificação dos principais problemas ambientais, os indicadores são revistos por meio de um procedimento cíclico de retroalimentação. 
Da mesma forma, os objetivos são utilizados na previsão de impactos em que são confrontados com os objetivos da ação em questão e no estabelecimento de um sistema de monitoramento.

É por isso que a seleção dos temas, objetivos e indicadores é uma etapa tão importante da $\mathrm{AAE}$, pois ela deve influenciar quais dados e informações serão levantadas para a base ambiental, quais previsões de impactos serão feitas e o sistema de monitoramento estabelecido. Assim, qualquer equívoco na seleção de objetivos deverá limitar a $A A E$ ou transformá-la num processo tendencioso (THERIVEL, 2004).

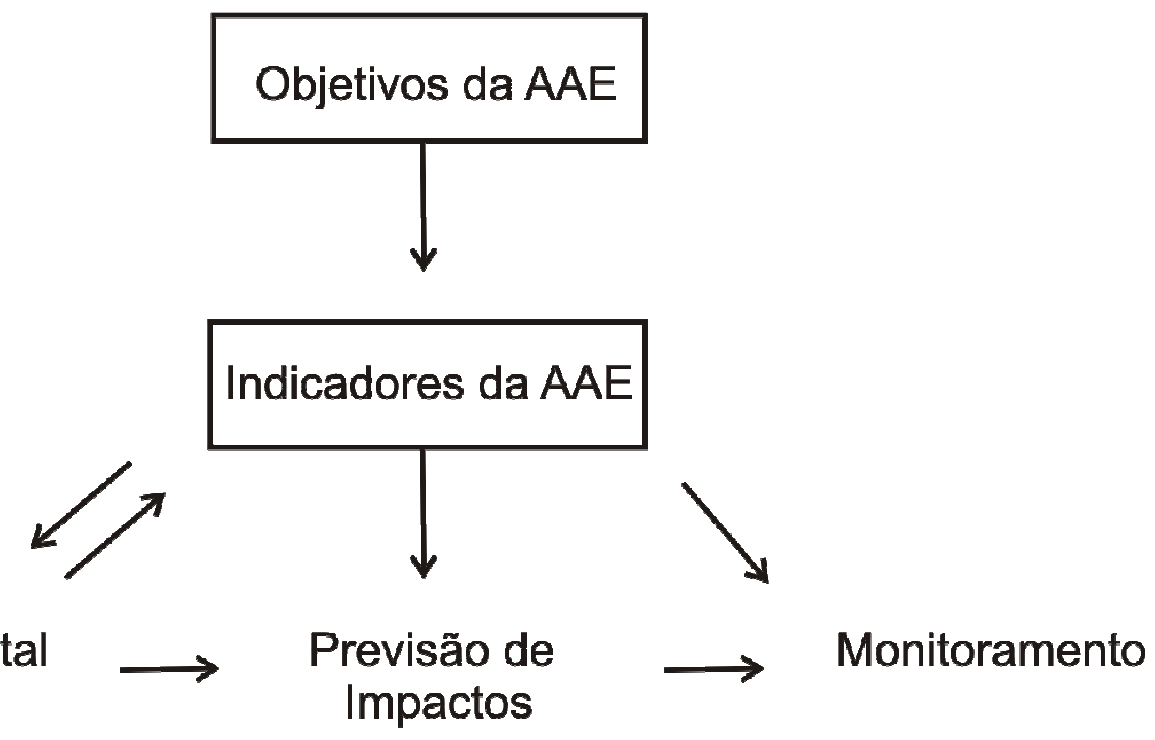

Base Ambienta Impactos

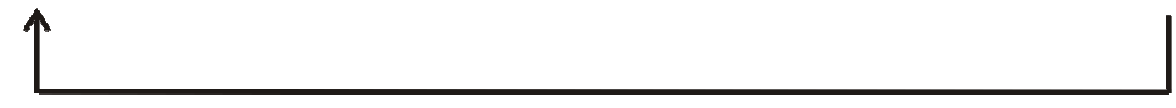

Figura 6. Links entre objetivos e indicadores e outras fases da AAE Fonte: Therivel (2004) 


\subsubsection{Base ambiental e problemas ambientais pertinentes}

Therivel (2004) define a base ambiental como o ambiente atual e o provável futuro ambiente na ausência da ação estratégica em questão. Como o próprio nome sugere, a base ambiental fornece a base para a previsão de impactos e o monitoramento, além de permitir a identificação dos problemas ambientais pertinentes. A base ambiental reúne um conjunto de informações que devem ilustrar possíveis conflitos entre as condições atuais do ambiente e situações (objetivos) ideais e desejáveis.

As principais questões que envolvem a base ambiental estão relacionadas a quais informações serão levantadas, de onde serão coletadas e de que forma organizá-las e torná-las úteis na avaliação. Therivel (2004) destaca o fato de que as informações devem ser relevantes e apropriadas à escala espacial da política em questão. Para isso, os objetivos identificados anteriormente ajudam a manter o foco e restringem o levantamento dessas informações sobre a área afetada.

A mesma autora chama atenção para o perigo de que a base ambiental seja tratada apenas como um "retrato" instantâneo de determinado momento, quando na verdade as condições ambientais estão em contínua mudança. Daí a importância de garantir sistemas de monitoramento e de coleta de informações de forma constante. A base ambiental deve identificar possíveis lacunas e ausência de dados, por falta de fonte de informações, que devem ser incluídos em futuros sistemas de monitoramento.

A base ambiental pode ser apresentada de modo variado, mas as formas mais comuns são na forma de mapas, útil para apresentar cenários, informações que têm elementos espaciais e possíveis mudanças no decorrer do tempo; e as 
informações que não podem ser mapeadas, na forma de gráficos, diagramas e matrizes.

\subsubsection{Relação com outras ações estratégicas}

As ações estratégicas são inevitavelmente influenciadas por outras políticas, planos e programas, assim como podem ter impactos significativos sobre outros PPPs. Essa etapa da AAE tem como objetivo identificar esses links, ou seja, de que forma a ação estratégica em estudo pode ter impactos significativos sobre outros PPPs, objetivos de proteção ambiental já estabelecidos, a legislação em vigor ou como pode ser influenciada por eles.

Essa etapa aparece muitas vezes na forma de tabelas de avaliação de conformidade ou atrelada à seleção dos objetivos da $\mathrm{AAE}$, derivados dos objetivos de proteção ambiental de outros PPPs. Assim, esse processo permite que se tire vantagem de possíveis sinergias e que os objetivos de outros PPPs sejam incorporados à política em discussão, oferecendo oportunidades para que diferentes níveis hierárquicos de tomada de decisão influenciem ações subseqüentes.

\subsubsection{Identificação de alternativas}

É a análise de diferentes alternativas, ou seja, de formas diferentes de atingir objetivos, que garante a abordagem proativa dos PPPs em relação aos problemas ambientais. Segundo Therivel (2004), sem um instrumento como a AAE, as alternativas são geralmente propostas de forma reativa, ou seja, em resposta aos problemas, em vez de serem focadas em diferentes formas de se alcançar uma 
visão de futuro. A AAE, portanto, poderia auxiliar na identificação de alternativas mais sustentáveis, fazendo da tomada de decisão algo mais proativo e transparente.

Um dos princípios básicos também da avaliação de impacto ambiental de projetos, a análise de alternativas na $A A E$, se diferencia pelo fato de permitir discussões e questionamentos estratégicos sobre as necessidades e demandas da sociedade, as diferentes formas de suprir essas necessidades e a intensidade de desenvolvimento que se pretende para determinadas áreas e/ou setores. Isso implica dizer que a gama de alternativas disponíveis é muito maior nesses casos e que nem sempre elas aparecem de forma delimitada e restrita como as alternativas locacionais de projetos (local A x local B), mas são apresentadas muitas vezes como um conjunto de opções que, combinadas de maneiras diferentes podem formar diversos cenários.

É claro que as opções de alternativas disponíveis e a maneira como estas são apresentadas devem variar consideravelmente de acordo com o nível estratégico. Em políticas, elas são muito mais abrangentes e estão geralmente relacionadas a conceitos e visões gerais. Já em programas, elas apresentam elementos que se aproximam da avaliação de projetos como aspectos espaciais e locacionais de desenvolvimento.

\subsubsection{Previsão, avaliação e mitigação de impactos}

Os objetivos, indicadores e a base ambiental identificados anteriormente representam papel fundamental e são base para a previsão de impactos. Eles serão confrontados com os objetivos do plano e a base ambiental deve permitir a análise dos efeitos da ação estratégica, seus impactos diretos, indiretos e cumulativos. 
O fato de a AAE lidar com amplas áreas, atividades e efeitos, inevitavelmente, traz certo grau de incerteza à previsão e à avaliação de impactos. Muitas das abordagens utilizadas para previsão e avaliação de impactos em AAEs são de caráter qualitativo e subjetivo, o que não desmerece a qualidade do método, porém, é possível que modelos matemáticos, sistemas de informações geográficas e outras técnicas de mapeamento sejam utilizados com cada vez mais freqüência, especialmente, na avaliação de impactos indiretos e cumulativos (THERIVEL, 2004).

A prática mostra que as avaliações baseadas em opiniões pessoais ainda são preponderantes. Recentemente, uma análise de AAEs realizadas no Reino Unido, feita por Therivel e Walsh (2006), permitiu identificar que $81 \%$ das técnicas utilizadas nos diversos estágios da avaliação ambiental estratégica envolvem essencialmente a opinião e o julgamento pessoais. Matrizes de impacto e análises de compatibilidade, técnicas que também se apóiam basicamente em opiniões de especialistas, constituem $10 \%$ das técnicas utilizadas. Mapeamento e sistemas de informações geográficas (SIG) compõem $6 \%$ do total e apenas $2 \%$ das técnicas utilizadas envolvem algum grau de complexidade como técnicas de modelagem e análise de cenários. É importante destacar também que mesmo essas técnicas envolvem julgamentos e opiniões pessoais.

Essa constatação somente reafirma o importante papel desempenhado pela participação da sociedade nesse processo de avaliação, ponderação e julgamento. É necessário destacar também o fato de que o papel da AAE é fornecer informações para a tomada de decisão. A decisão será, essencialmente, política, porém, as informações disponibilizadas e as conseqüências avaliadas e tornadas públicas, 
somadas ao peso da opinião pública, tendem a aumentar a influência das questões ambientais no jogo político.

\subsubsection{Documentação, implementação e monitoramento}

Brown e Therivel (2000) acreditam que a preparação de um relatório de AAE é provavelmente a parte menos importante de uma avaliação ambiental estratégica. Essa visão surge da necessidade de afirmar a AAE como instrumento integrado à tomada de decisão e ao ciclo de formulação de políticas, planos e programas.

O relatório final da $A A E$, porém, desempenha importante papel no momento em que torna público o modo como as questões ambientais foram consideradas no processo político. Mesmo que, na prática, a decisão política contrarie as sugestões e recomendações da $\mathrm{AAE}$, o relatório traz essas questões à tona e torna claro a maneira como as questões ambientais foram consideradas.

Em muitos casos, utiliza-se a consulta pública para apresentação do rascunho do relatório da $A A E$, não significando isso que as observações das pessoas envolvidas serão levadas em consideração. Essa etapa representa, muitas vezes, um processo formal de comunicação dos resultados da AAE.

Therivel (2004) destaca a necessidade de inclusão de um plano com diretrizes para implementação das sugestões e modificações propostas pela AAE e identificação de responsabilidades institucionais além de um sistema de monitoramento, por intermédio dos indicadores e objetivos estabelecidos inicialmente. 


\subsubsection{Participação}

Diversos benefícios podem ser associados ao envolvimento da sociedade na avaliação de impacto ambiental de ações estratégicas, principalmente porque leva em conta o conhecimento local, resulta em decisões politicamente mais aceitas e faz com que políticas, planos e programas reconheçam e reflitam as aspirações da sociedade (THERIVEL, 2004).

$\mathrm{Na}$ prática, porém, diversos fatores tornam isto um pouco mais complexo, podendo tomar diferentes formas e alcançar diferentes resultados. A participação pode variar desde simples consultas em que o público é informado e tem a oportunidade de opinar, sem que a sua opinião resulte necessariamente em mudanças na ação em foco; até formas mais abrangentes de envolvimento em que certos representantes da sociedade conseguem e têm o poder de influenciar a tomada de decisão.

A AAE deve refletir aspirações da sociedade, em termos de proteção do meio ambiente, e esse é, sem dúvida, um dos maiores desafios na prática. Rauschmayera e Risseb (2005) identificam alguns critérios a serem levados em consideração no momento do estabelecimento de formas de participação em AAEs. Os autores chamam a atenção para a consideração das seguintes questões:

- gestão da informação: garantir que diferentes fontes de informação (científica, popular,local e experimental) sejam levadas em consideração;

- legitimidade: garantir que todos os grupos de interesse relacionados com a questão sejam identificados, incluídos e/ou representados, de forma que haja uma participação equilibrada e legítima; 
- dinâmica social: facilitar a busca por objetivos convergentes e reconhecer a tomada de decisão como um processo social que envolve grupos de interesses diversos e que essa relação pode evoluir para situações que permitem às pessoas discutir, mudar perspectivas e rever suas opiniões e decisões;

- custos: considerar questões de custo-benefício. Algumas formas de consultas superficiais e pouco abrangentes podem ser financeiramente mais atraentes, mas correm o risco de se transformarem em processos pouco efetivos e com resultados equivocados, o que pode suscitar questionamentos por parte da sociedade.

\subsection{Desafios para adoção da AAE no setor de turismo no Brasil}

A atuação do Estado brasileiro no campo do turismo não é um fenômeno recente. Pereira (1999) aponta a década de 1930 como o período das primeiras iniciativas governamentais que estabeleceram normas legais com vistas à regulação dessa atividade. Desde então, várias ações marcaram a atuação do governo no setor do turismo, especialmente a criação da então Empresa Brasileira de Turismo (EMBRATUR), ainda na década de 1960, o Conselho Nacional de Turismo (CNTur), a formulação de políticas nacionais e, mais recentemente, a criação do Ministério do Turismo, em 2002, quando Brasil passou por um significativo avanço na institucionalização da gestão do turismo.

Apesar do avanço, diversas dificuldades e obstáculos ainda podem ser identificados na gestão do setor, principalmente no que diz respeito à quase inexistência de ações inter-setoriais, à falta de ações conjuntas e integradas entre 
órgãos de turismo (federal, estadual e municipal) e destes com os demais órgãos da administração pública, à necessidade de aumentar e fortalecer os canais de cooperação e participação da iniciativa privada e do terceiro setor, e à acentuada modificação no processo diretivo em cada mudança de governo com alterações abruptas de direcionamento das políticas públicas, o que acarreta descontinuidade administrativa e indefinição de prioridades políticas para o setor (BENI, 2001; PEREIRA, 1999; SILVEIRA, PAIXÃO e COBOS, 2006).

São obstáculos, presentes na realidade brasileira, que, sem dúvida, devem configurar como entraves ou desafios em futuras aplicações de AAE no cenário da gestão do turismo.

Dalal-Clayton e Sadler (2005) relacionam ainda uma série de outros empecilhos que a aplicação da AAE deverá encontrar em países em desenvolvimento como o Brasil, especialmente aqueles relacionados às questões políticas e institucionais, capacidade técnica e profissional limitada, entraves burocráticos, conflitos de interesses, corrupção, estruturas organizacionais fechadas e compartimentadas, além da falta de objetivos e políticas ambientais claras.

O desenvolvimento do turismo, por si só, demanda interfaces com outras políticas recorrentes e complementares, tornando-se necessário um intenso trabalho de coordenação com outros setores (PEREIRA, 1999). Com a AAE, esse trabalho de coordenação e incorporação de objetivos de outras políticas, planos e programas se torna não só importante mas essencial. A pouca experiência em promover ações inter-setoriais no Brasil, no entanto, deve dificultar a garantia de princípios da integração vertical e horizontal em futuras experiências de AAE.

Uma conseqüência dessa falta de integração é que os planos de turismo falham em incorporar questões ambientais e sociais decorrentes de suas ações, 
apresentando uma abordagem essencialmente voltada para o mercado e para o crescimento econômico.

No Brasil, o Plano Nacional de Turismo (2003-2007) é o documento mais estratégico, atualmente em vigor, que exprime o posicionamento do governo em relação ao setor, e foi estabelecido para orientar e nortear o desenvolvimento dessa atividade em âmbito nacional. Seus objetivos estão essencialmente relacionados ao desenvolvimento de produtos turísticos de qualidade, às ações de estímulo e facilitação do consumo nos mercados nacional e internacional e da ampliação da oferta de produtos e de postos de trabalho, ou seja, o planejamento do turismo no País ainda apresenta uma abordagem fundamentalmente econômica, voltada para o cumprimento de metas econômicas e geração de novos empregos.

O Plano reconhece o turismo como importante agente da valorização e conservação do patrimônio ambiental, porém não incorpora em seus objetivos valores relacionados à proteção dos recursos ambientais em que a atividade se apóia. Em todos os níveis da administração pública, a legislação prevê uma série de instrumentos de política ambiental como é o caso da avaliação de impacto ambiental, o zoneamento ambiental, os instrumentos de planejamento territorial, o estabelecimento de padrões de qualidade, o licenciamento ambiental, dentre outros. Esses instrumentos podem garantir estratégias de gestão ambiental que beneficiam o desenvolvimento do turismo de forma mais responsável. Porém, as políticas de turismo no Brasil falham em integrar essas questões ambientais em seus objetivos.

Além disso, D'leteren (2006) destaca que as etapas da AAE deverão se adaptar à forma e estrutura em que se dá o processo de planejamento do turismo no país (as etapas seguidas, os grupos de interesse relacionados, os canais de participação pública já existentes, as informações ambientais disponíveis etc.). 
Segundo o autor, o processo de AAE também vai depender de como as questões ambientais são levadas em consideração no sistema de planejamento em caso. A figura a seguir ilustra as relações entre os diversos agentes institucionais que compõem o atual sistema de gestão do turismo no Brasil. Qualquer tentativa de inserção da AAE nas políticas de turismo no País deve levar em consideração essa estrutura, seus agentes, suas funções e relações.

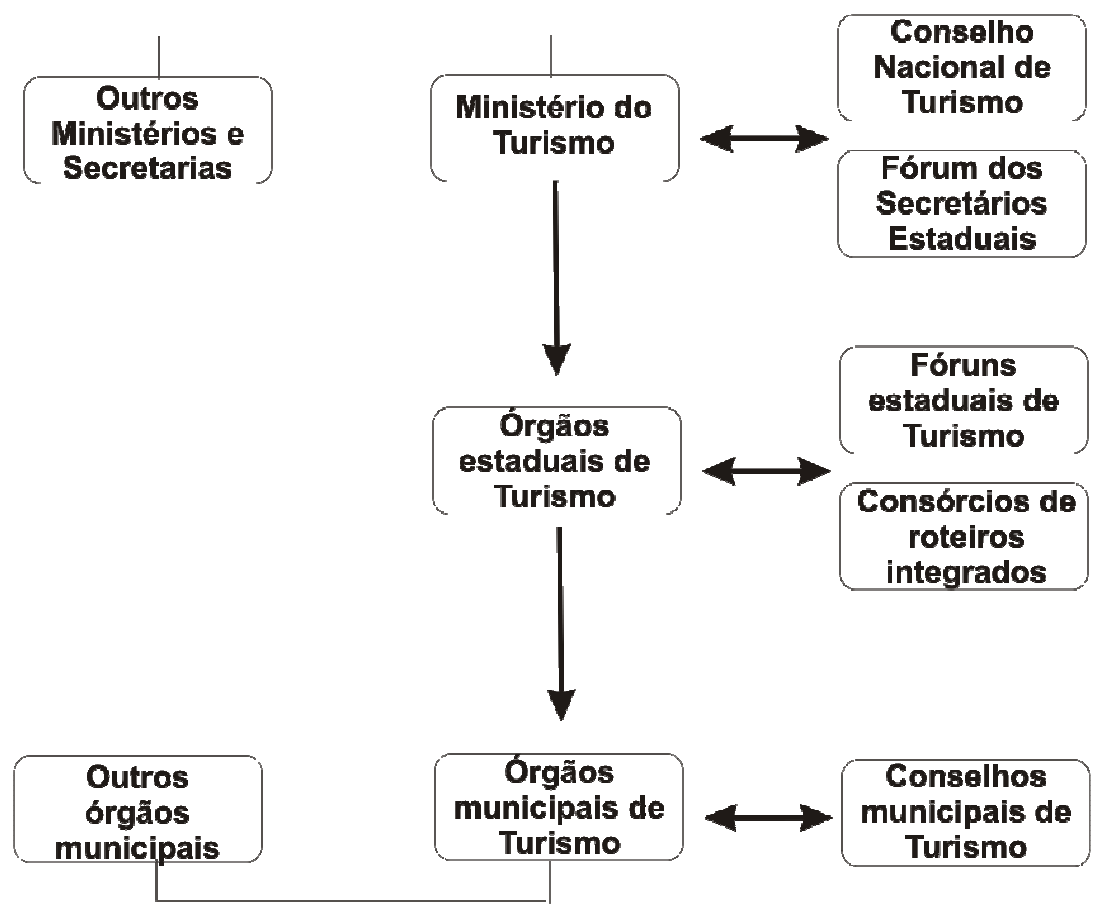

Figura 7. Sistema institucional da gestão do turismo no Brasil Fonte: Adaptado de Ministério do Turismo (2003) e Beni (1991)

No caso do Brasil, além da falta de integração institucional, é possível que um outro fator que deve dificultar a aplicação da AAE seja a ausência de um sistema nacional de informações sobre o meio ambiente e de monitoramento e coleta contínua e sistematizada dessas informações, visto que um dos principais elementos 
da AAE é o estabelecimento de uma base ambiental com informações que devem ilustrar as condições atuais do ambiente e situações (objetivos) ideais e desejáveis.

Agra Filho (2002) sugere que, tendo em vista a precária base de informações disponíveis sobre a realidade ambiental, a adoção da AAE seja preliminarmente conduzida em setores e regiões de escalas compatíveis com a disponibilidade de uma prática de gestão ambiental e com a demanda dessas informações. Por outro lado, o que se espera de um instrumento como a AAE é que a sua adoção seja capaz de estimular ou até coagir o Poder público a fornecer essas informações. Até lá, outras fontes como universidades, institutos de pesquisa, organizações não governamentais e a própria sociedade podem ser úteis no fornecimento de informações ambientais.

Além disso, não é corrente no País a prática de tornar público o processo de planejamento e de divulgar informações consideradas estratégicas. O fato de a grande maioria das instituições públicas brasileiras ainda serem muito fechadas em relação à participação efetiva da sociedade nas discussões estratégicas e na tomada de decisão também é fator limitante para a transparência do processo de avaliação ambiental estratégica.

Porém, é preciso lembrar que o País já dispõe de vários canais que, de alguma forma, facilitam ou oferecem oportunidade para algum tipo de participação da sociedade civil como os procedimentos de ação civil pública, os comitês de gestão de bacias, os conselhos de meio ambiente, os órgãos colegiados de âmbito nacional, estadual e municipal etc. É possível, portanto, que esses canais e essas experiências já existentes sejam aproveitados em futuras aplicações de AAE.

Dentre esses canais de participação, os que mais se destacam na gestão do turismo são os Conselhos (Federal, Estaduais e Municipais) de Turismo, geralmente 
órgãos que funcionam de forma colegiada e que prestam assessoramento no sentido de propor diretrizes, oferecer subsídios e contribuir para a formulação e implementação das políticas para o setor. Mais recentemente, com o objetivo de promover uma integração territorial de destinos turísticos que apresentam características semelhantes ou complementares em termos dos atrativos, dos equipamentos e serviços, da infra-estrutura e do estágio de desenvolvimento, algumas regiões estão adotando o modelo de gestão regional, por meio de consórcios de roteiros integrados, conforme está ilustrado na figura 7.

A participação de outros agentes no planejamento do turismo está relacionada com outro fenômeno recente, a redefinição do papel do Estado nesse setor. Até meados dos anos de 1980, o Estado atuava de forma mais direta, como "empreendedor" ou como interventor, passando, paulatinamente, nas últimas duas décadas, a privatizar atividades sob sua responsabilidade direta e a propor políticas de corte mais regulatório e descentralizador (PEREIRA, 1999).

Ainda na década de 1980, boa parte dos Estados brasileiros aderiu à privatização de seus hotéis, companhias aéreas etc. Além disso, atualmente, o modelo de intervenção e planejamento do setor está sendo revisto. Esse debate vem sendo promovido principalmente pelo próprio Estado, que, diante das transformações em curso na economia mundial e frente às exigências de ordem fiscal e à necessidade de elevar a competitividade do turismo, está buscando rever o seu próprio papel. Dessa forma, propõe-se, hoje, um novo modelo de gestão turística, com ampla participação da iniciativa privada e de diversos segmentos da sociedade civil organizada. Com essa proposta, o Estado evidencia a intenção de restringir a sua atuação no turismo e de dividir a responsabilidade das funções assumidas no transcurso da história (QUEIROZ, 2001). 
Essas recentes tendências no trato da gestão do turismo, em que se evidencia o papel da iniciativa privada, das organizações do terceiro setor e de representantes das populações afetadas pelo desenvolvimento turístico, podem ser consideradas positivas no momento em que apresentam cenários favoráveis para inserção desses representantes em futuras aplicações de AAE.

grande desafio do processo de inserção da sociedade nas discussões e tomadas de decisão estratégicas, no entanto, não é apenas garantir a existência de canais e formas de participação, mas fazer com que esses mecanismos não se restrinjam a instâncias decisórias de estágio final do processo de tomada de decisão, em que a sociedade é chamada para ser comunicada e pouca influência exerce na formulação propriamente dita das políticas.

$\mathrm{Na}$ prática, vários desafios podem ser identificados. A experiência de implantação de um modelo de gestão participativa na gestão do turismo na Costa do Descobrimento, na Bahia, dá mostras dessas dificuldades. A criação de um Conselho Regional de Turismo mostrou uma situação de resistência dos atores que relutavam em descentralizar, horizontalizar e flexibilizar o processo de gestão. Além disso, percebeu-se a falta de confiança das pessoas entre si, o desnível de informação entre sociedade civil e governo, a falta de experiência dos participantes em projetos associativos e o elevado grau de individualismo. É muito comum também encontrar casos em que os Conselhos Municipais são "prefeiturizados", mantendo e legitimando as pequenas classes políticas e grupos dominantes da sociedade local, em detrimento do estabelecimento de canais locais de participação nos quais as comunidades possam ter maior possibilidade de integração e diálogo. (SANT'ANNA, OLIVEIRA e BERENSTEIN, 2001). 
Beni (1991) também apontou como grande dificuldade para o melhor desempenho operacional do Sistema Nacional de Turismo a carência de mão-deobra qualificada e especializada, com a conseqüente ausência de pesquisas científicas, bem como a escassez de recursos financeiros para o exercício de uma administração pública mais profissional. Apesar do aumento dos cursos de graduação e pós-graduação da área, e, consequentemente do maior número de profissionais especializados, a carência de mão-de-obra qualificada ainda é marcante, especialmente nos municípios de menor porte. Se essa é uma realidade no setor de turismo, é possível que a falta de experiência e capacidade técnica no campo da avaliação ambiental estratégica também seja um grande empecilho para a sua operacionalização.

Outra questão levantada por Irving (2002) diz respeito à necessidade de desenvolvimento de uma proposta de turismo no Brasil que esteja diretamente vinculada à uma estratégia de educação ambiental que considere, prioritariamente, a questão da participação e do envolvimento da comunidade, o desenvolvimento de programas formais e informais, os códigos culturais e comportamentais das comunidades a serem trabalhadas, a perspectiva da atuação interinstitucional, a transdisciplinaridade, a integração entre 0 setor público e 0 privado, o desenvolvimento de recursos humanos com base local, o desenho de parcerias na busca de um modelo de co-responsabilidade e a sustentabilidade das iniciativas propostas.

Dentre os principais desafios, portanto, destacou-se aqui a necessidade de fortalecer a integração interinstitucional; identificar interfaces com outros instrumentos da política ambiental; garantir mecanismos de integração e incorporação de princípios da AAE em todos os níveis de planejamento (PPPs); 
adaptar a AAE aos processos de planejamento e estruturas institucionais já existentes; integrar ações de planejamento com estratégias de educação ambiental; facilitar a abertura e a transparência do processo de planejamento, fortalecendo e aumentando os canais de participação pública no processo decisório; além de criar um sistema de referência ambiental estratégico, que possa nortear e condicionar o desenvolvimento turístico no País. 


\section{TURISMO E MEIO AMBIENTE}

\subsection{Turismo e impactos ambientais}

Para discutir e entender de que forma a avaliação ambiental estratégica pode colaborar para o desenvolvimento do turismo de forma mais responsável e menos impactante, é preciso entender de que modo essa atividade se relaciona com o ambiente natural, suas possíveis conseqüências positivas e negativas nas áreas das quais depende para seu desenvolvimento. Isso porque, segundo Therivel (2004), uma $A A E$ deve estar focada em questões-chave relacionadas à atividade que está sendo avaliada.

No Brasil, o incentivo a investimentos por parte dos governos estaduais e federal, o aumento de oportunidades de acesso ao crédito e os programas de investimento por parte de agências multilaterais de desenvolvimento colaboram de forma significativa para o crescimento do setor turístico no País.

Um exemplo dos esforços por parte do Poder público em incentivar o desenvolvimento do turismo no Brasil é o Programa de Desenvolvimento do Turismo no Nordeste (PRODETUR). Só na sua primeira fase, finalizada em 2005, esse programa destinou US\$625,966 milhões para obras de infra-estrutura, saneamento básico e suporte ao turismo (aeroportos, urbanização de áreas turísticas, centros de convenções, recuperação de patrimônio histórico), com recursos oriundos do Banco Interamericano de Desenvolvimento (BID), com a contrapartida da União, dos estados e demais órgãos executores. Para a segunda fase do programa, estão 
previstos investimentos da ordem de US $\$ 400,00$ milhões (BANCO DO NORDESTE, 2006).

Além disso, os bancos públicos federais, gestores dos programas oficiais de financiamento para o turismo, desembolsaram, somente no período de janeiro a junho de 2006 , um total de $R \$ 1,1$ bilhão. Houve um incremento de $4,3 \%$ no volume de recursos direcionados às atividades turísticas, em projetos de investimentos para ampliação, modernização e instalação de empreendimentos turísticos e operações de capital de giro. De 2003 a junho de 2006, os bancos desembolsaram para o setor um total de $\mathrm{R} \$ 5,6$ bilhões (MINISTÉRIO DO TURISMO, 2006).

O nível de investimento da iniciativa privada também continua alto. Em outubro de 2006, nada menos do que 188 hotéis, com capacidade para mais de 5 mil habitações, estavam em construção no País, somando assim investimentos de R\$ 3,5 bilhões (HOTÉIS, 2006).

Esses números mostram tendências de forte crescimento da atividade e diversos benefícios podem ser relacionados a essa situação. Sob o ponto de vista econômico, é extremamente animador, afinal, o turismo é responsável pela criação de postos de trabalho, além de ser um grande dinamizador da economia.

Boullon (2000) acredita que, diferentemente de outras atividades econômicas mais intensamente consumidoras de recursos naturais, o turismo não implica necessariamente uma transformação radical do recurso natural, já que a atividade de seus consumidores, os visitantes, se resume a simples contemplação das paisagens naturais. Ruschmann (1997) também acredita na contribuição do 'turismo de natureza' para a proteção do meio ambiente. Além disso, a autora defende a atividade turística em zonas rurais como fator de recuperação da ordem econômica e social dos espaços que abandonaram sua função original, protegidos ou não. 
É preocupante, no entanto, quando se consideram as possíveis conseqüências ambientais que o turismo pode ocasionar ao meio ambiente, já que essa atividade não é constituída simplesmente de contemplação de paisagens naturais. O turismo pode trazer uma série de efeitos negativos, como consumo excessivo de energia e das reservas de água, geração de resíduos, lançamento de efluentes em corpos d’água, desmatamento de áreas verdes e ocupação de áreas ambientalmente sensíveis, distúrbios à vida silvestre etc. Além disso, é cada vez mais comum, especialmente em países em desenvolvimento, o fenômeno da especulação imobiliária e da remoção de populações locais e/ou tradicionais de suas regiões de origem, em nome da construção de grandes projetos imobiliários, recreativos e hoteleiros.

Na década de 1980, Krippendorf (1989) já registrava a oposição da população autóctone na Suíça em relação ao turismo conduzido irresponsavelmente em diversas regiões. Ali várias comunidades e estações de férias famosas rejeitaram projetos que implicavam um crescimento suplementar do turismo. Junto à população, se formaram comitês, associações, grupos de trabalho e iniciativas populares, que tomavam posição contra os projetos turísticos de grande porte e contra a invasão das construções que descaracterizavam a paisagem, lutando assim em prol do desenvolvimento harmonioso da região.

No Brasil existem vários casos de conflitos que envolvem o aumento do fluxo turístico em áreas até então pouco ocupadas. Um exemplo disso são as políticas de incentivo ao turismo no litoral norte da Bahia e sua influência no desmatamento de áreas de restinga, dunas e mata atlântica da região. Com apoio do Poder público local, as áreas de proteção estão passando por constantes mudanças em seu zoneamento com o intuito de facilitar a construção de mais empreendimentos 
hoteleiros. Estudos do Ministério do Meio Ambiente concluíram ainda que o aumento do desmatamento em nome do desenvolvimento turístico no local não está resultando em ofertas de emprego nem melhorando o índice de desenvolvimento humano dos municípios afetados (BELÉM, 2006).

Levando em conta as possíveis conseqüências adversas que o desenvolvimento turístico pode causar, Wearing e Neil (2001) consideram preocupante a situação de euforia e expectativa que se forma em torno dos efeitos positivos resultantes do turismo, já que as conseqüências econômicas, sociais e ambientais negativas são estabelecidas ao longo do tempo, sendo sentidas somente depois dos primeiros impactos econômicos positivos. Outro resultado é que esses benefícios imediatos são muitas vezes superestimados e se acumulam nas contas públicas, enquanto os ônus social e ambiental ficam por conta das comunidades locais.

Na prática, portanto, o desenvolvimento turístico não funciona de forma tão inofensiva e o consumo turístico não se resume à contemplação e uso indireto de áreas naturais. Segundo Dias (2003), o turismo não planejado pode, a médio e longo prazo, ensejar mais conseqüências negativas do que positivas sobre a sociedade local.

Gössling (2000) releva o fato de que o que poderiam ser consideradas formas sustentáveis de turismo ainda representam uma parcela muito pequena no setor, talvez menor do que $5 \%$, e alguns impactos como o uso excessivo de energia e suas conseqüências globais são praticamente excluídos da discussão da sustentabilidade no turismo. Ele destaca o uso de combustíveis fósseis para deslocamento, aquecimento, refrigeração, limpeza, alimentação, transporte, importação de alimentos e outros produtos etc. 
O turismo pressupõe o deslocamento de pessoas, o que necessariamente está relacionado ao uso de energia. E numa sociedade fortemente dependente do uso de combustíveis fósseis, esse deslocamento está associado a efeitos extremamente negativos.

O discurso a respeito dos efeitos que o deslocamento para viagens internacionais pode ter sobre o efeito estufa e o aquecimento global pode parecer distante da realidade de países em desenvolvimento como o Brasil, em que viagens internacionais ainda são privilégios de uma pequena parcela da população. Essa questão, todavia, já é preocupação e alvo de debate corrente em diversos países desenvolvidos, haja vista o aumento significativo do número de viagens nos últimos anos e as perspectivas de crescimento contínuo que o setor prevê.

Segundo a OMT (2005), 45\% dos 806 milhões de turistas que viajaram em 2005 utilizaram o transporte aéreo como meio de locomoção (ver figura 8). Esse fato ganha importância, quando se analisa a contribuição do setor de transporte para problemas globais como o efeito estufa, o buraco na camada de ozônio e o fenômeno da chuva ácida. Ainda muito dependente de combustíveis fósseis, o transporte aéreo causa ampla degradação ambiental. Além disso, é aquele que, dentre os setores de transporte, origina maior emissão de $\mathrm{CO}_{2}$ per capita (SIMÕES, 2003). 


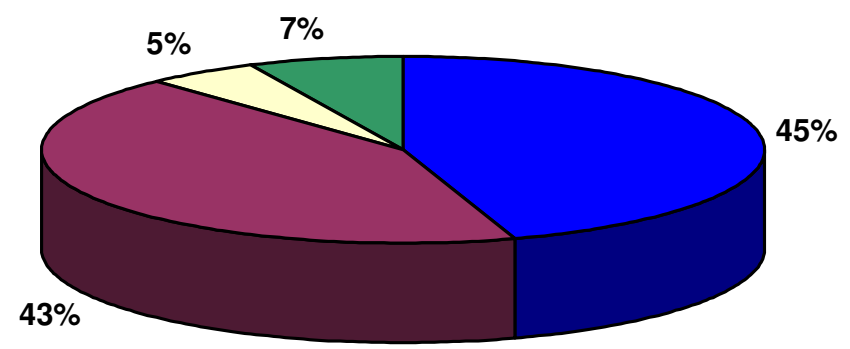

$\square$ Aéreo

$\square$ Rodoviário

$\square$ Ferroviário

$\square$ Marítimo

Figura 8. Meios de transporte utilizados no turismo internacional Fonte: Organização Mundial do Turismo (2005)

Cenários indicam que o setor de transportes como um todo crescerá cerca de 40\% nos próximos 20 anos. Tal crescimento, obviamente, impulsionará as emissões de $\mathrm{CO}_{2}$, causando preocupantes problemas ambientais locais e globais (SIMÕES, 2003).

O mesmo autor afirma que, em termos globais, o transporte rodoviário é a atividade que produz a maior parte das emissões de $\mathrm{CO}_{2}$. Tendo em vista as altas taxas de emissão de $\mathrm{CO}_{2}$ per capita, o transporte aéreo é, portanto, um dos principais responsáveis pelo incremento do efeito estufa. A figura a seguir ressalta a importância do setor de transportes em termos de consumo de energia em forma de petróleo. 


\section{- Transporte Aéreo}

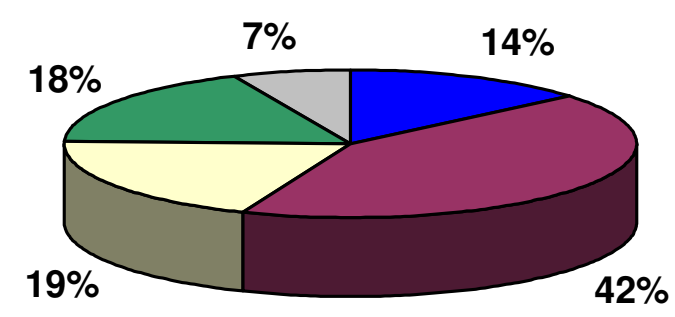

\section{$\square$ Rodoviário + \\ Hidroviário + \\ Ferroviário \\ $\square$ Indústria}

$\square$ Outros Setores

\section{$\square$ Uso não energético}

Figura 9. Distribuição percentual do consumo mundial de petróleo por setor, ano 2000 Fonte: Simões (2003)

Além de estimular o consumo energético por meio do setor de transportes, o turismo, segundo Dias (2003), é um intenso consumidor de território, um dos elementos básicos dessa atividade. Dessa forma, o turismo condiciona a organização do espaço, pois o utiliza, consome e transforma, o que situa o próprio setor turístico como, potencialmente, um dos principais agentes de destruição dos recursos em que se apóia.

Boullon (2000) destaca ainda que o fato de que o turismo segue a tendência de se localizar nas áreas do espaço físico que Ihe são mais favoráveis. Isso equivale àqueles locais dotados de condições propícias, onde se encontra a matéria-prima que o abastece, isto é, locais de grande beleza cênica, rica biodiversidade, e, naturalmente, grande sensibilidade ao desenvolvimento e à presença antrópica intensa.

Por outro lado, para que ocorra, o turismo pressupõe o desenvolvimento de certa infra-estrutura, como vias de acesso, meios de hospedagem, centros de compras e facilidades, opções de lazer e outros serviços. É esse processo, de 
transformação e adaptação do local em função da demanda turística por infraestrutura, que coloca o destino turístico em risco de autodestruição.

No Brasil, a região costeira, historicamente uma das mais populosas do País e um dos principais atrativos do turismo nacional, apresenta várias situações negativas advindas do aumento do fluxo turístico e do desenvolvimento nocivo que a expansão desordenada dessa atividade pode causar.

Em Florianópolis, há pelo menos 30 anos, as belezas do local atraem uma leva impressionante de turistas, empresários e aventureiros. O avanço imobiliário, conseqüência do aumento do turismo, provoca a degradação contínua das dunas e restingas, além de comprometer o lençol freático e a balneabilidade das praias e trazerem problemas graves, como o aumento da geração de resíduos e a poluição (MARTORANO, 2006).

As áreas naturais, como zonas costeiras, parques nacionais, ilhas, bancos de corais, regiões montanhosas etc., de maneira geral, têm um apelo muito forte para atração de fluxos turísticos, fazendo com que as regiões próximas a esses atrativos sejam alvo de forte pressão de desenvolvimento. Em outras atividades econômicas, o valor paisagístico, a beleza cênica, a proximidade com áreas selvagens não é fator condicionante, ao contrário do turismo, que necessita da proximidade desses fatores para a viabilidade do empreendimento, o que pode induzir uma série de conseqüências negativas. Por isso, em qualquer lugar em que acontece o desenvolvimento turístico, deve-se considerar o impacto dos espaços construtivos da infra-estrutura turística e de apoio que virão atender o fluxo de visitantes.

Um exemplo desses impactos induzidos, citado por Powell et al (2002), ocorreu na Costa Rica, onde a região de entorno do complexo de Reservas de Monteverde, um conjunto de seis áreas protegidas públicas e privadas, se encontra 
sob forte pressão de desenvolvimento, porque novos moradores são atraídos para Monteverde por causa do aumento da atividade turística.

Essas áreas naturais protegidas legalmente, além de representativas de ecossistemas de grande importância para a conservação de diversos habitats e espécies, são importante recurso utilizado pelo turismo, podendo atrair considerável fluxo turístico e influenciar uma série de investimentos e benefícios econômicos para a região de entorno.

No mundo todo, o número de áreas protegidas cresceu substancialmente nos últimos 25 anos (ver tabela 1). No mais recente levantamento realizado pela União Internacional para a Conservação da Natureza e dos Recursos Naturais (IUCN), foram identificadas 102.102 áreas protegidas (em 1962 esse número era de cerca de 10.000 áreas), abrangendo quase 18,8 milhões de $\mathrm{km}^{2}$ (CHAPE et al., 2003).

Tabela 1 - Áreas naturais protegidas no mundo

\begin{tabular}{ccc}
\hline Ano & Número de Áreas Protegidas & Área $\left(\mathbf{k m}^{2}\right)$ \\
\hline 1962 & 9.214 & 2.4 milhões \\
1972 & 16.394 & 4.1 milhões \\
1982 & 27.794 & 8.8 milhões \\
1992 & 48.388 & 12.3 milhões \\
2003 & 102.102 & 18.8 milhões \\
\hline
\end{tabular}

Fonte: Chape et al. (2003)

Esse crescimento significativo de áreas protegidas reflete o aumento do compromisso político em preservar áreas remanescentes de grande importância 
para a manutenção da biodiversidade, mas também é conseqüência dos valores sociais e culturais que a sociedade estabelece em relação a essas áreas (CHAPE et al., 2003). Nesse ponto, o turismo representa papel fundamental, na medida em que permite que a sociedade não só conheça e aprecie essas áreas como formas de lazer, mas que a sensibilização que a visita pública traz ao visitante se transforme em apoio público para a proteção desses importantes remanescentes de biodiversidade.

Além disso, o turismo em áreas naturais é freqüentemente saudado como um dos poucos exemplos de desenvolvimento sustentável que funciona, porque não apenas ajuda a assegurar a preservação, in situ, das áreas selvagens, mas também origina retorno econômico a partir das terras postas de lado para conservação. Assim, essa atividade é cada vez mais explorada de forma a proporcionar um fundamento econômico lógico para a preservação dessas áreas naturais, em vez de desenvolvê-las para outros usos como a agricultura ou a exploração de madeiras. $\mathrm{Na}$ Costa Rica, os benefícios econômicos trazidos por centenas de postos de trabalho relacionados ao turismo nutrem a aceitação pelas áreas naturais protegidas (POWELL et al., 2002; DAVENPORT et al., 2002).

O uso turístico dessas áreas, conseqüentemente, suscitou discussões em diversas partes do mundo. Isso porque, no passado, o turismo era a menor ameaça às áreas protegidas, por causa da distância e da dificuldade de acesso. Nos últimos anos, porém, a situação mudou muito, já que as áreas de proteção se tornaram cada vez mais importantes, com aumento significativo no número de visitantes e, por isso, intensificação dos impactos (WEARING e NEIL, 2001).

A presença humana em ambientes naturais pode trazer sérias conseqüências à manutenção do equilíbrio ecológico dessas áreas. Magro (1999) relata uma série 
de impactos ambientais mais comuns, resultantes da visitação em áreas naturais, como a perda de vegetação e conseqüente erosão do solo, distúrbios à fauna, contaminação da água, incêndios e presença de lixo.

Na Tailândia, o Parque Khao Yai dá sinais de impactos resultantes da visitação intensa. Com mais 1,2 milhão de visitas a cada ano, o local recebe um tráfego intenso, pesado e barulhento de pessoas nos fins de semana. A concentração de atividades humanas já está dando sinais de perturbação a algumas espécies locais como elefantes e o boi selvagem asiático. Apesar disso, a visitação intensa faz de Khao Yai um local extremamente popular, com uma massa de simpatizantes que provavelmente auxilia a salvá-lo de muitas outras ameaças (SRIKOSAMATARA e BROCKELMAN, 2002).

A ocorrência do impacto nessas áreas protegidas é conseqüência inevitável do uso, sendo preciso que se lance mão dos instrumentos necessários para o manejo e gestão dessas áreas, especialmente sobre o solo, vegetação, fauna e água, os principais elementos a serem afetados com a visitação pública.

O desenvolvimento do turismo seja ele em áreas protegidas, zonas rurais ou urbanas, etc. também ocasiona, via de regra, o uso direto de recursos naturais, especialmente água e energia e, conseqüentemente, a geração de resíduos e efluentes. Essas questões ganham proporções maiores à medida que 0 desenvolvimento do turismo atrai um número cada vez maior de pessoas, acostumadas a padrões relativamente mais altos de consumo, para ambientes naturais e culturais antes isolados ou afastados (COHEN, 1978). Esse fato faz com que surjam diversas situações de conflitos de uso, especialmente em benefício dos turistas e em detrimento do bem-estar da população local. 
Apesar da sua limitada disponibilidade, as águas subterrâneas são recursos dos mais intensamente demandados pela indústria do turismo em áreas costeiras, o que traz riscos de superexploração desse recurso, podendo ocasionar rebaixamento do lençol freático, comprometimento da qualidade da água, invasão de água salgada etc. Na Tunísia, em zonas costeiras de grande desenvolvimento turístico, o lençol freático já mostra sinais de esgotamento, quando seu uso foi desviado da agricultura para abastecer empreendimentos turísticos, trazendo grandes conflitos com agricultores locais (GÖSSLING, 2001).

Segundo Gössling (2001), o consumo de água por turista por dia, nos hotéis de luxo da região do Mediterrâneo, chegava a 600 litros no ano de 1984. Mais recentemente, em pesquisa junto aos hotéis da ilha de Zanzibar, na África, o autor identificou o fato de que o consumo pode variar de 100 até 2.000 litros / por turista / por dia. Na alta estação, que coincide com o período de seca na ilha, o consumo aumenta e a população local já está sentindo os sintomas do desenvolvimento intenso da infra-estrutura turística na região. Estudos indicaram aumento nos níveis de nutrientes dos aqüíferos costeiros próximos a hotéis e há relatos de invasão de água salgada nas águas subterrâneas.

A quantidade de água e energia consumidas, geralmente, é proporcional ao tamanho do hotel. Hotéis maiores usam mais água, provavelmente por conta da grande infra-estrutura, das piscinas e dos jardins irrigáveis, os dois maiores itens de consumo de água, e demandam mais energia para aquecimento ou refrigeração de seus espaços, iluminação etc.

Essas questões levantam uma série de discussões quanto ao tipo de turismo que se desenvolve nos destinos, as conseqüências ambientais que ele acarreta, quem se beneficia com esse desenvolvimento, o papel do Poder público na gestão 
desses conflitos, a responsabilidade dos investidores e da iniciativa privada e o nível de participação da sociedade na tomada de decisão.

Tendo em vista os conflitos que essa atividade pode acarretar, cada vez mais se reconhece a necessidade de se estabelecer limites ao desenvolvimento do turismo. Diversos autores (MORGAN e ONORIO, 2000; OMT, 2003; RUSCHMANN, 1997; WEARING e NEIL, 2001) defendem modos mais responsáveis ou sustentáveis de turismo e, conseqüentemente, menos impactantes.

Sobre isso, Hunter (1997) assinala que o debate em torno de modos mais sustentáveis de turismo está geralmente dissociado de discussões a respeito do conceito de desenvolvimento sustentável, normalmente definido como forma de atender às necessidades atuais sem que se comprometa a possibilidade das gerações futuras atenderem as suas, como se isso fosse suficiente para esclarecer e encerrar a discussão sobre o assunto. Assim, é comum encontrar na literatura defensores do turismo sustentável, sem que haja uma discussão mais aprofundada sobre o assunto, o que produz uma interpretação teórica dominante do termo totalmente desprovida de claridade e profundidade.

O autor defende $o$ argumento de que diversas interpretações sobre o que seja turismo sustentável são apropriadas, de acordo com cada circunstância. Turismo sustentável, portanto, não deveria ser visto como uma estrutura ou conceito rígido, mas como um paradigma capaz de aceitar diferentes abordagens e formas de desenvolvimento, de acordo com cada realidade. Isso porque a magnitude e o tipo de desenvolvimento turístico devem variar de acordo com as características ambientais de cada local. Além disso, o autor acredita que seja essencial, na gestão de modos mais responsáveis de turismo, a presença do Poder público, como forma 
de controlar o desenvolvimento, e alguma forma de envolvimento da sociedade no planejamento e na tomada de decisão.

\subsection{Instrumentos de gestão ambiental para o turismo}

São vários os fatores que influenciam a ocorrência de impactos ambientais negativos de atividades turísticas e a intensidade e freqüência com que eles ocorrem. Esses impactos devem variar, principalmente, de acordo com (COHEN, 1978; OMT, 2003 e SIMPSON e WALL, 1999):

\section{- A intensidade do uso turístico}

O volume de visitantes, o tempo de permanência no local e a concentração da utilização turística em locais e épocas específicas determinam a intensidade do uso turístico. Quanto maior é o fluxo, maior deverá ser a pressão que esses visitantes acarretam sobre as áreas naturais e urbanas e os recursos a elas associados.

- Tipo de utilização ou de atividade turística

O tipo de atividade turística (atividades desenvolvidas e as facilidades requeridas) está diretamente relacionado aos impactos ocasionados. Algumas atividades são mais intensivas no uso de recursos naturais, emitem mais ruídos e resíduos e/ou demandam maior quantidade de facilidades (infra-estrutura, suprimentos, mão-de-obra, matérias-primas etc.).

\section{- Características da área de destino}

Os ambientes diferem em termos de fragilidade, sensibilidade e capacidade de recuperação. As características do meio ambiente, portanto, influenciam na sua capacidade de absorver impactos. Algumas áreas são mais suscetíveis ao dano 
ambiental do que outras e suas características naturais é que devem condicionar sua capacidade de receber fluxos turísticos e a infra-estrutura associada.

\section{- Gestão e contexto político}

Os impactos estão intimamente relacionados aos tipos de planejamento e estratégias de gerenciamento associados à atividade turística. A maioria dos casos de impactos negativos da atividade ocorre em áreas onde há pouco controle, gerenciamento de má qualidade ou inexistente e um sistema legal falho.

Em um estudo realizado no Parque Nacional do Itatiaia, Serrano (1997) analisou o uso do local por turistas e visitantes e chama a atenção para o fato de que o argumento do impacto turístico, que por vezes justifica a interdição de algum tipo de uso do local por visitantes, em geral, mascara a insuficiência ou a incompetência administrativa, pois os impactos inerentes da atividade turística em áreas naturais podem ser atenuados por uma série de medidas de controle e gestão.

Esse fato confirma a idéia de que são as estratégias de gerenciamento e os instrumentos de gestão utilizados que devem influenciar de modo mais significativo os níveis de impacto ocasionados pela atividade turística, já que a maioria dos casos de impactos negativos do turismo ocorre em áreas onde há pouco controle, gerenciamento de má qualidade ou inexistente e um sistema legal falho; e são as estratégias de gestão que permitem o controle dos outros fatores causadores de impacto.

Para isso, nas últimas décadas, vários instrumentos de gestão foram desenvolvidos, com especial referência ao uso turístico de áreas naturais, no sentido de resolver os conflitos e impactos do turismo (BOYD e BUTLER, 1996). 
A capacidade de carga é um desses instrumentos, já amplamente aplicado em estratégias de controle de fluxos turísticos em áreas naturais, especialmente a partir da década de 1990, e é resultado de uma apropriação do conceito utilizado na gestão de pastagens, para determinar o número de animais que podem ser mantidos em determinada área de pasto. No turismo, sua adoção consiste no cálculo de um número máximo de visitas/dia que uma determinada área natural pode suportar (CIFUENTES, 1992).

Fazendo uma análise sobre estudos e experiências de capacidade de carga em distintas partes do mundo, Pires (2005) identificou vários enfoques de abordagem desse conceito. De maneira geral, a aplicação desse instrumento está relacionada ao estabelecimento de um número máximo de usuários ou atividades permitidas em determinada área ou na determinação dos níveis de degradação ecológica que possam ser considerados aceitáveis.

As principais críticas referem-se ao fato de que estabelecer número de visitantes para áreas naturais é muito mais um conceito intuitivo do que científico e que a magnitude do impacto não é necessariamente condicionada pelo número de turistas. Wearing e Neil (2001) também são críticos desse método e garantem que a prática de limitar o número de visitantes é, muitas vezes, uma solução imprópria e simplista.

Exemplo disso é o estudo sobre efeitos provocados pelos passeios de barco (observação e nado com golfinhos) em Northland, na Nova Zelândia. Constantine, Brunton e Baker (2003) afirmam que parece não existir uma relação direta entre a magnitude do impacto e o número de barcos e banhistas, mas sim, com o tempo de exposição desses animais a esses encontros, resultando em impactos cumulativos significativos. Os autores sugerem, portanto, que seja preferível que todos os barcos 
interajam com os golfinhos em um mesmo período delimitado do que distribuí-los em um período mais extenso.

Outros sistemas de gerenciamento e manejo de visitantes baseados em condições sociais e ambientais desejáveis representam uma reformulação do conceito de capacidade de carga, de forma a compensar e/ou suprir algumas de suas limitações.

Lindberg, McCool e Stankey (1997) defendem o argumento de que o foco do manejo das visitas a áreas naturais deve ser "quais são as condições desejáveis" em vez de simplesmente estabelecer números máximos de visitantes. É essa visão de gestão, baseada no desenho de indicadores, cenários e monitoramento, que caracteriza os sistemas de manejo como o LAC (Limits of Acceptable Change), VIM (Visitor Impact Managment), VERP (Visitor Experience Resource Protection), dentre outros.

Freixêdas-Vieira, Passold e Magro (2000) mostram que esses métodos apresentam em comum o fato de se basearem em condições sociais e ambientais desejadas para o futuro, e, por meio do monitoramento da área, avalia-se se as ações de manejo estão produzindo os resultados esperados sem alterar outras características da experiência ou do ambiente.

Nota-se, portanto, uma evolução do manejo da visitação pública em áreas naturais, partindo do simples controle do número de pessoas, estabelecido pela capacidade de carga, a instrumentos que estabelecem padrões e condições ambientais de mudanças aceitáveis e o contínuo monitoramento dessas questões. Identificados os impactos e suas causas, pode-se estabelecer estratégias de controle e redução de impactos, sejam elas a limitação do número de pessoas ou outras ações de manejo, como Educação Ambiental, mudanças nas regras para 
atividades desenvolvidas no interior da área, mudanças no traçado de trilhas, no zoneamento da área etc.

Existe ainda uma série de mecanismos de planejamento e gerenciamento que costumam ser adotados no controle de fluxos turísticos em áreas naturais como os sistemas de permissões e licenças de operação, necessárias para o funcionamento de operadoras turísticas em determinadas áreas controladas; a aplicação de taxas de visitação, que podem ser úteis tanto para a manutenção e desenvolvimento da infra-estrutura local, como podem funcionar como reguladoras de demanda, reduzindo problemas de excesso de procura; e a definição de padrões de qualidade ambiental mínima.

Constata-se, porém, que, apesar de algumas diferenças de enfoque e metodologia, esses instrumentos têm em comum o fato serem pouco aplicáveis a outras situações que não a visitação em áreas naturais protegidas. Pires (2005) já chamou atenção para o fato, ao afirmar que, quando se trata de considerar espaços de recreação e turismo não protegidos na forma de unidades de conservação, como as praias, cidades, áreas rurais ou outros espaços com recursos naturais demandados para a mesma finalidade, esses modelos têm a sua aplicação, se não inviabilizada, altamente dificultada.

Outro instrumento também conhecido e amplamente utilizado em vários países e com forte influência no desenvolvimento de atividades turísticas é o zoneamento. Sua principal interface com o turismo, mais uma vez, diz respeito fundamentalmente ao uso público de unidades de conservação.

Exemplo disso é o uso que se faz do zoneamento para o planejamento espacial da Grande Barreira de Corais na Austrália, como forma de mediar conflitos de usos desse parque marinho de aproximadamente $345.000 \mathrm{~km}^{2}$. O zoneamento 
divide o local em áreas de acordo com seus possíveis usos, como as áreas de pesquisas, navegação, pesca, mergulho, turismo, proteção de habitats, zona de amortecimento, área de preservação etc. (DAY, 2002).

Em outros casos, fora de áreas naturais protegidas, o zoneamento está geralmente associado ao planejamento territorial do solo mediante 0 estabelecimento de zonas com diferentes tipos e intensidades de uso. Essa abordagem se aproxima do modelo de "zoneamento do uso do solo urbano", citado em Ranieri et al (2005), em que o seu resultado origina um mapa com identificação de zonas e suas respectivas indicações de usos permitidos e proibidos. Os autores destacam o fato de que essa abordagem está presente na maioria das definições de zoneamento, apresentado como um instrumento com função de ordenamento territorial que tem o poder de intervir sobre o direito de propriedade e estabelecendo limitações a esse direito.

Os autores constataram que no Brasil existe ampla gama de produtos (materializados na forma de mapas e relatórios a eles associados), aos quais foi atribuída a denominação de zoneamento ambiental ou qualquer outra semelhante, conforme o interesse da equipe ou instituição responsável pela sua elaboração. Observando esses estudos, os autores concluíram que a maioria dos produtos de zoneamentos foi elaborada, normalmente, com boas intenções, mas desconsiderando a existência e a necessidade de articulação com os demais instrumentos da Política Nacional de Meio Ambiente: licenciamento ambiental, avaliação de impactos ambientais, padrões de qualidade, sistemas de informações ambientais etc.

A avaliação de impacto ambiental, outro instrumento amplamente utilizado em várias partes do mundo, também apresenta importante interface com o turismo, pois 
cada vez mais se reconhece a sua importância como parte de avaliações de propostas de desenvolvimento turístico (HUNTER,1995).

Butler $^{6}$ (1991 apud HUNTER, 1995, p.122), contudo, já observava que, em muitas localidades, e por muitos anos, as avaliações de impacto de empreendimentos turísticos ocorriam, na maioria das vezes, de forma reativa, quando já haviam sido aprovados esses projetos.

Essa constatação não é exclusiva do setor de turismo e, como já afirmado, a realidade mostra que a avaliação de impacto ambiental nem sempre é capaz de garantir que as questões ambientais sejam incorporadas na concepção e elaboração de projetos e empreendimentos.

Morgan e Onorio (2000) ainda chamam a atenção para o fato de que os impactos cumulativos do turismo devem ser considerados, o que, geralmente, não acontece mediante a avaliação de impacto ambiental de projetos, que considera apenas os impactos diretos. Assim, torna-se evidente a necessidade de uma avaliação das políticas governamentais de incentivo ao turismo, antes da aprovação de projetos específicos para determinadas localidades.

Por outro lado, é muito comum, especialmente no setor do turismo, que os representantes da iniciativa privada defendam a auto-regulamentação, feita por intermédio de códigos de conduta, esquemas de certificação e credenciamento e regulamentos próprios, como métodos preventivos de conflitos entre a atividade e as questões ambientais.

Essa atitude ativa da indústria em relação aos seus conflitos ambientais é sempre a solução preferida pela própria indústria, em vez da submissão a

\footnotetext{
${ }^{6}$ Butler, R.W. Tourism, environment, and sustainable development. Environmental Conservation, vol. 18, $n^{\circ}$ 3, p. 201- 209, 1997. Apud HUNTER, C. (1995). Environmental impact assessment and tourism development. In: HUNTER, C.; GREEN, H. Tourism and the environment: a sustainable relationship? London: Routledge. Cap.5, p.121-168.
} 
regulamentações e outras medidas de controle por parte do Estado. A autoregulamentação, no entanto, em relação a essas questões ambientais, nem sempre foi bem-sucedida em outros setores, como na mineração e na agricultura (WEARING e NEIL, 2001). É necessário cautela nesses casos, já que a atuação do Estado pode ser decisiva para evitar que o desenvolvimento turístico implique prejuízos significativos à qualidade ambiental local.

No Brasil, constata-se atualmente, que grandes investimentos em complexos turísticos construídos pela iniciativa privada, a maioria dos quais estimulados e incentivados por governos estaduais, não obedecem a preceitos do planejamento sustentável do turismo (BENI, 2001); ou seja, o próprio Poder público também não consegue garantir que suas ações de estímulo a essa atividade ocorram sem prejuízos ao meio ambiente e aos reais interesses das populações locais.

Nesses casos, a ponderação dos fatores ambientais e sociais não é compromisso explícito de políticas de incentivo a grandes investimentos, em que os fatores econômicos são mais considerados. Argumenta-se, portanto, que a adoção da avaliação ambiental estratégica é uma forma de dar um peso maior para essas questões no jogo da decisão política.

No turismo, a necessidade da AAE ganha força, pois, em muitos destinos turísticos, a explosão de investimentos em obras e empreendimentos de grande porte - como hotéis, resorts, estradas e aeroportos - são resultados de políticas de atração e incentivo por parte do Poder público, em nome da criação de empregos e da entrada de divisas. Além disso, muitas das conseqüências negativas do turismo são resultados de impactos induzidos e sinérgicos. A necessidade de avaliações estratégicas, portanto, é indiscutível. 
Por outro lado, Swarbrooke (2000) também destaca o fato de que, muitas vezes, é difícil perceber o que pode ser alcançado com o planejamento por parte do Estado na área de turismo, considerando que o setor público não possui nem é capaz de controlar muitos dos elementos-chave do produto turístico e que, por essa razão, o conceito de parceria cresceu em popularidade nos últimos anos. Acreditase que, nesses casos, a AAE pode facilitar a interlocução e o diálogo do Estado com as demais partes interessadas da sociedade.

A política de turismo é definida por Beni (2001) como um conjunto de decisões que, integradas harmonicamente no contexto da política nacional de desenvolvimento, orientam a condução do setor e regulam as ações a serem executadas, as quais se traduzem em planos e programas de desenvolvimento setorial.

Programas e planos de desenvolvimento, por sua vez, influenciam os projetos, por isso, acredita-se que a AAE pode condicionar o desenvolvimento de certos projetos, assim como reduzir esforços e recursos dos estudos de impacto ambiental.

Além disso, à medida que o mundo volta suas atenções para a busca do desenvolvimento sustentável, o conceito de AAE aufere cada vez mais importância e urgência (PARTIDÁRIO e CLARK, 2000). O turismo, como atividade consumidora de recursos naturais, não foge a essa regra. O desafio da conservação ambiental como fator condicionante para a sustentabilidade do turismo é discutido e estudado pela comunidade científica mundial.

Boyd e Butler (1996), ao analisarem os instrumentos de gestão mais utilizados para o controle turístico em áreas naturais, já assinalavam a necessidade da elaboração de diretrizes capazes de avaliar as oportunidades do turismo frente a 
outros possíveis usos dos recursos naturais, e que levassem em consideração as necessidades das comunidades e a significância dos impactos ambientais e sociais do desenvolvimento turístico.

Da mesma forma, a OMT (2003) chama a atenção para a antecipação dos impactos do desenvolvimento como função essencial de um plano turístico e acentua que avaliar os impactos ambientais se tornou um padrão e, em muitos lugares, uma exigência do processo de planejamento.

Nesses casos, como destaca Dias (2003, p.35), "o Estado, em todos os níveis, ainda é o único agente capaz de articular amplas forças da sociedade numa perspectiva de planejar um desenvolvimento identificado com a preservação do meio ambiente, socialmente justo e economicamente viável'.

Entende-se, portanto, que as iniciativas de gestão ambiental na atividade turística não podem estar restritas ao controle de fluxo em áreas naturais, a medidas compensatórias para os impactos causados pelo número excessivo de visitantes, ou à auto-regulamentação por parte da indústria, já que essas condições têm origem e são resultados de questões políticas e estratégicas que envolvem o planejamento local.

Sendo assim, o Estado tem importante papel a desempenhar, pois detém a responsabilidade total, coletiva, de assegurar que os benefícios auferidos com 0 turismo, inclusive os financeiros, não sejam obtidos em detrimento das necessidades sociais, culturais e ambientais (BENI, 2001).

Acredita-se, portanto, que a AAE pode ser utilizada como um instrumento que venha a suprir essas falhas, garantindo que critérios ambientais sejam considerados em questões estratégicas de incentivo ao turismo. 


\subsection{Interface com a AAE e outros instrumentos}

Os investimentos em infra-estrutura e o conseqüente aumento da oferta turística, vistos como potenciais geradores de renda, empregos e impostos, ocorrem, na maioria dos casos, de forma dissociada de uma estratégia de desenvolvimento capaz de prever os impactos ambientais que essa atividade possa vir a causar. É por isso que esses mecanismos de gerenciamento mais contingenciais (gerenciamento de visitação em áreas protegidas, sistemas de permissões e licenças de operação, aplicação de taxas, padrões de qualidade ambiental, avaliação de impacto ambiental de projetos e a auto-regulamentação por parte da iniciativa privada), utilizados de forma isolada, são insuficientes para evitar impactos significativos.

O turismo, já mostrado aqui como potencial consumidor intensivo de território, tem muito a se beneficiar dos instrumentos de planejamento do uso do solo, especialmente o Plano Diretor, adotado em escala municipal, e o zoneamento, regulamentado no Brasil como Zoneamento Ecológico-Econômico e, geralmente, adotado em escalas maiores (contexto estadual ou regional).

O Plano Diretor deve englobar todo o território municipal e é obrigatório para municípios em áreas de especial interesse turístico. Salvati (2004) explica que o plano diretor incorpora questões referentes ao planejamento turístico no momento em que estabelece princípios e normas para:

- a implantação de infra-estrutura viária;

- o sistema de transporte;

- o saneamento básico;

- a destinação de resíduos sólidos; 
- a conservação e recuperação de ecossistemas e do patrimônio histórico e cultural; e

- o desenvolvimento urbano e rural.

O zoneamento, geralmente associado ao planejamento territorial do solo, pode ser útil para o ordenamento do turismo, no momento em que identifica diferentes tipos de zonas e suas respectivas indicações de usos permitidos e proibidos, ou seja, estabelece limites para uso e ocupação do solo. Em unidades de conservação, seu uso é reconhecido como essencial, na medida em que concentra a visitação em áreas reconhecidas como próprias para esse fim, preservando outras consideradas mais frágeis.

Em outras situações, Ranieri et al. (2005) vêem o zoneamento - no Brasil adotado como instrumento que impõe restrições de uso do solo urbano - com certa ressalva no que diz respeito à sua função de auxílio à gestão. Isso porque, adotado em escala nacional ou regional, o zoneamento se transforma num instrumento extremamente denso e, em função da quantidade de informações necessárias, o tempo gasto entre a coleta de dados e o resultado final tornaria o zoneamento um instrumento defasado, no que diz respeito aos cenários e diretrizes estabelecidos. Além disso, ao avançar na normatização e restrição de uso do solo, o zoneamento pode entrar em conflito com a competência municipal de legislar sobre o seu território.

Estabelecidos princípios e normas para uso e ocupação do solo, a avaliação de impacto ambiental é útil, no momento em que permite a análise de viabilidade ambiental de certos empreendimentos. A avaliação de impacto ambiental foi regulamentada no Brasil pela Resolução 01/86 do CONAMA e tem como uma de suas principais funções a análise das alternativas locacionais, levando em 
consideração fatores ambientais, para atividades de potencial significativo impacto ambiental. Como já mostrado, a AIA é utilizada de forma ampla na avaliação da viabilidade ambiental de empreendimentos turísticos com potencial impacto significativo no meio ambiente.

Nooteboom (2000), por sua vez, defende a opção de que a avaliação de impacto ambiental de projetos não é suficiente para avaliar a coerência ou a compatibilidade de políticas de desenvolvimento setorial com os objetivos de política ambiental; função, aliás, que nem os mecanismos de ordenamento do uso do solo conseguem suprir. É esse o papel, portanto, da avaliação ambiental estratégica e, por isso, a AAE deve complementar (grifou-se) os instrumentos já disponíveis e utilizados atualmente e não substituí-los. Além disso, por estar relacionada com questões mais estratégicas, ela não só antecede a AIA de projetos e o ordenamento de uso do solo como também estabelece melhor contexto para a aplicação desses instrumentos.

É necessário, portanto, enfatizar que a AAE não pode ser vista como substituta da AIA de projetos, ou seja, como uma forma de se ultrapassarem as dificuldades inerentes à avaliação ambiental de projetos. Além disso, nem a AAE tem relação com o EIA ou a comparação de alternativas, sejam estas mais ou menos importantes, nem o processo de EIA deve ser ocasião de discussão de decisões estratégicas tomadas em etapas anteriores na hierarquia de planejamento (PARTIDARIO, 2000).

Ranieri et. al (2005) destacam ainda a necessidade de identificação, dentro da atual Política Nacional de Meio Ambiente, de um instrumento estruturador, que deve refletir os padrões de qualidade do meio e apresentar as aptidões ambientais de determinado território e, portanto, oferecer subsídios e informações ambientais 
que serão posteriormente utilizadas na implementação de outros instrumentos, especialmente a avaliação de impacto ambiental. Assim, seria possível pensar nos instrumentos da Política Nacional de Meio Ambiente de forma articulada e complementar, cada um cumprindo sua função específica.

A articulação entre esse instrumento estruturador e a avaliação de impacto ambiental, portanto, sucede no âmbito de projeto, no momento da concepção do empreendimento em si, especialmente no que diz respeito a escolhas locacionais; e no âmbito estratégico, como base de informação ambiental capaz de indicar aptidões do território para as diversas atividades humanas condicionando assim as políticas públicas, os planos e os programas decorrentes. Dessa forma, tanto empreendedores quanto gestores públicos estariam munidos de informações relacionadas aos aspectos ambientais do território e sua relação com as atividades sob exame.

No caso do turismo, atividade que necessita da proximidade de áreas de grande valor estético, paisagístico e histórico, e, na maioria dos casos, de significativa fragilidade, esse instrumento pode oferecer informações que garantam que o desenvolvimento turístico e a infra-estrutura que o apóia não ocorram em detrimento dos recursos naturais dos quais essa atividade depende.

Assim, a pressão dos fluxos turísticos em áreas naturais ou outros sítios sujeitos às conseqüências negativas da visitação pública é regulada não só por instrumentos de gerenciamento de impactos mais pontuais, como a aplicação de taxas e o controle do número de visitantes, mas por instrumentos estratégicos, capazes de avaliar a compatibilidade da atividade turística com objetivos de proteção ambiental. 


\section{TURISMO E AVALIAÇÃO AMBIENTAL ESTRATÉGICA}

A Diretiva Européia (2001/42/EC) estabelece que todos os planos e programas preparados por autoridades nacionais, regionais e locais, sujeitos à apreciação legislativa, regulatória ou administrativa, das áreas de agricultura, silvicultura, pesca, energia, indústria, transporte, resíduos, água, telecomunicações, turismo e planejamento territorial são sujeitos à avaliação ambiental.

Dalal-Clayton e Sadler (2005) defendem a posição de que, no geral, todas as áreas da política que concernem ou conduzem a mudanças no uso de terra e de recursos naturais e/ou da geração de poluentes e resíduos são candidatas potenciais a objetos de AAE. Dentre essas áreas, certamente, se enquadra o turismo.

Como conseqüência, a aplicação desse instrumento como forma de garantir modos mais responsáveis e menos impactantes de turismo é testada cada vez mais freqüentemente, e como será mostrado a seguir, recentemente diversos países realizam experiências de AAE para esse setor.

Numa análise da prática internacional, identificou-se uma série de estudos de caso de turismo e AAE. Essas experiências começaram a ocorrer de maneira tímida na década de 1990, mas, nos últimos anos, observou-se um crescimento significativo desses estudos, em diversos níveis de planejamento (políticas, planos e programas), com diferentes abordagens e formas de aplicação. As análises a seguir pretendem identificar experiências bem-sucedidas e as possíveis falhas e desafios que envolvem a aplicação de AAE em políticas de turismo. 


\subsection{Estudos de caso}

Os quadros a seguir relacionam esses estudos com alguns princípios já citados anteriormente que envolvem a elaboração da AAE. Foram selecionadas 14 experiências de $A A E$, de diversos continentes, aplicadas em políticas, planos e programas específicos do setor de turismo, planos de desenvolvimento ou planejamento territorial de cidades ou regiões de forte vocação turística, e, por último, AAEs de regiões de parques nacionais que recebem grande fluxo turístico, em âmbitos nacionais, regionais e locais.

Certamente essa análise não é exaustiva e outras experiências ficaram de fora, principalmente por conta da dificuldade de conseguir esses estudos em língua acessível. Esses casos, todavia, representam boa parte do que já foi feito de $A A E$ para esse setor e a partir deles pode-se tirar diversas conclusões sobre formas de aplicação, resultados alcançados e desafios a superar.

Além dessas experiências, foram identificados também estudos e reflexões sobre aplicação da AAE em políticas de turismo; encontradas em Antarctic and Southern Ocean Coalition (ASOC) (2000), Hemmings e Roura (2003) e Kuo et al. (2005). 


\begin{tabular}{|c|c|}
\hline \multicolumn{2}{|r|}{ SEA of the Neiafu Master Plan, Vava'u, Tonga } \\
\hline Âmbito de aplicação & Plano de Desenvolvimento da cidade de Neiafu, uma cidade turística das ilhas do Pacífico Sul (1996). \\
\hline Objetivo da ação & $\begin{array}{l}\text { Seu objetivo geral é melhorar a qualidade de vida da população local, facilitando o desenvolvimento } \\
\text { de três atividades: pesca, agricultura e turismo. }\end{array}$ \\
\hline Quem fez & $\begin{array}{l}\text { Executado pelo South Pacific Regional Environment Program (SPREP) e financiado pela União } \\
\text { Européia. }\end{array}$ \\
\hline Momento de realização & O plano começou a ser elaborado em 1993 e a AAE foi realizada em 1996. \\
\hline Participação pública & Não houve. \\
\hline Referências de sustentabilidade & Não existem. \\
\hline Consideração de alternativas & $\begin{array}{l}\text { O estudo é um típico modelo de avaliação de propostas já elaboradas e, por isso, não é feita a } \\
\text { consideração e avaliação de alternativas ao plano. Apenas a AAE propõe algumas readequações dos } \\
\text { objetivos e modificações às propostas iniciais do plano. }\end{array}$ \\
\hline Monitoramento & $\begin{array}{l}\text { O estudo propõe um monitoramento do plano e estabelece alguns aspectos prioritários a serem } \\
\text { monitorados, porém, é superficial e não detalha metodologia e nem responsabilidades. }\end{array}$ \\
\hline Observações & $\begin{array}{l}\text { A AAE foi realizada por uma equipe distinta daquela responsável pela elaboração do plano. Além } \\
\text { disso, o tempo disponível para a avaliação não foi suficiente para que as pessoas responsáveis pela } \\
\text { elaboração do plano fossem ouvidas. Apesar disso, uma parte das recomendações da AAE foi levada } \\
\text { em consideração na reformulação do plano; porém, a equipe reconhece que uma avaliação realizada } \\
\text { num estágio inicial teria poupado tempo e recursos. O plano se assemelha muito a um programa, na } \\
\text { medida em que prevê um conjunto de projetos e é resultado de um plano de desenvolvimento } \\
\text { regional. Não foi realizada uma AAE das ações estratégicas que lhe deram origem e isso dificultou a } \\
\text { reformulação dos objetivos. }\end{array}$ \\
\hline
\end{tabular}

Quadro 5. AAE do Plano de Neiafu, Vava'u, Tonga

Fonte: Morgan e Onorio (2000) 


\begin{tabular}{|c|c|}
\hline \multicolumn{2}{|c|}{ SEA of the Core Area Public Programing and Activities Vision, Ottawa, Canada } \\
\hline Âmbito de aplicação & Programa setorial de estímulo ao turismo na região central da cidade (2005). \\
\hline Objetivo da ação & $\begin{array}{l}\text { O programa tem como objetivo aumentar a oferta de atividades e experiências para visitantes e } \\
\text { turistas na região central de Ottawa. Ele consiste numa série de projetos previstos para a área. São } \\
\text { eles: construção de museus, áreas para eventos comemorativos e apresentações públicas, } \\
\text { desenvolvimento de novas rotas e alamedas para pedestres e veículos e intervenções nas margens } \\
\text { do rio Ottawa. }\end{array}$ \\
\hline Quem fez & $\begin{array}{l}\text { Preparado pela National Capital Comission, a própria instituição propositora do plano, juntamente } \\
\text { com uma consultoria externa, a G. A. Packman \& Associates. }\end{array}$ \\
\hline Momento de realização & AAE simultânea à elaboração do programa. \\
\hline Participação & $\begin{array}{l}\text { A participação de grupos de interesse se restringiu ao momento de elaboração dos documentos de } \\
\text { referência (Core Area Concept e Core Área Vision), que influenciaram a elaboração do programa. }\end{array}$ \\
\hline Referências de sustentabilidade & $\begin{array}{l}\text { As principais referências que guiam o desenvolvimento do programa são as informações presentes } \\
\text { nos dois documentos intitulados "Core Area Concept" e "Core Area Vision", porém, suas informações } \\
\text { se referem muito mais a questões conceituais sobre o que se espera para o desenvolvimento } \\
\text { sustentável da região, nos próximos } 25 \text { anos, do que referências práticas para operacionalizar o } \\
\text { conceito de sustentabilidade. }\end{array}$ \\
\hline Consideração de alternativas & $\begin{array}{l}\text { Não foi feita avaliação de alternativas, pois, segundo o documento, as alternativas serão analisadas } \\
\text { em etapa posterior (avaliação dos projetos individualmente). }\end{array}$ \\
\hline Monitoramento & $\begin{array}{l}\text { Não estabelece um plano de monitoramento propriamente dito, mas destaca alguns pontos e } \\
\text { requisitos importantes que devem ser incluídos em um futuro programa de monitoramento. }\end{array}$ \\
\hline Observações & $\begin{array}{l}\text { O estudo faz menção aos possíveis projetos de intervenção para a área e estabelece uma série de } \\
\text { critérios e requisitos a serem seguidos nas atividades de planejamento e construção. Além disso, } \\
\text { destaca os principais aspectos ambientais a serem considerados no momento dos estudos de } \\
\text { impacto ambiental desses projetos. A avaliação também faz indicações gerais quanto a questões } \\
\text { locacionais desses projetos (bairros, áreas naturais, alamedas etc.); avaliação de impacto, portanto, } \\
\text { que se aproxima do modelo normalmente adotado em projetos. }\end{array}$ \\
\hline
\end{tabular}

Quadro 6. AAE do Programa de atividades da região central de Ottawa, Canadá

Fonte: G.A.Packman \& Associates Environmental Consultants (2005) 


\begin{tabular}{|c|c|}
\hline \multicolumn{2}{|r|}{ SEA of the Fiji Islands Tourism Development Plan } \\
\hline Âmbito de aplicação & Plano Nacional de Desenvolvimento do Turismo (2003). \\
\hline Objetivo da ação & $\begin{array}{l}\text { Estabelecer uma estratégia de crescimento em larga escala do turismo na região. O plano passaria por } \\
\text { uma revisão e a AAE deveria oferecer subsídios para essa atualizacão. }\end{array}$ \\
\hline Quem fez & $\begin{array}{l}\text { Fruto de uma parceria entre o WWF e o Banco de Desenvolvimento Asiático (Asian Development Bank). } \\
\text { O WWF formou uma equipe composta por consultores externos. A AAE era também apoiada pelo } \\
\text { Ministério do Turismo e foi firmado um termo de entendimento entre o Ministério e o WWF. }\end{array}$ \\
\hline Momento de realização & AAE simultânea à atualização do plano. \\
\hline Participação pública & $\begin{array}{l}\text { Foi formado um grupo consultivo, responsável pela revisão e orientação das atividades, e formado por } \\
\text { grupos de interesse como representantes do WWF, empresários, instituições de turismo e ministérios. } \\
\text { Foram realizadas três reuniões, a primeira para avaliação do escopo do estudo; na segunda foram } \\
\text { discutidas as principais conclusões e na última foi feita uma revisão do relatório final. }\end{array}$ \\
\hline Referências de sustentabilidade & $\begin{array}{l}\text { A metodologia adotada foi baseada no modelo da Diretiva Européia }(2001 / 42 / E C) \text {. Foram utilizados } \\
\text { objetivos e indicadores de sustentabilidade, como as principais referências para serem confrontadas } \\
\text { com os objetivos do plano. }\end{array}$ \\
\hline Consideração de alternativas & $\begin{array}{l}\text { O estudo avalia todos os objetivos do plano e propõe uma série de mudanças, descritas na forma de } \\
\text { oito opções estratégicas a serem seguidas. Na prática, as alternativas do plano foram reformuladas para } \\
\text { ficarem de acordo com os objetivos de sustentabilidade elaborados anteriormente. }\end{array}$ \\
\hline Monitoramento & $\begin{array}{l}\text { Apesar de o estudo ter seguido um modelo semelhante ao da Diretiva Européia, a equipe trabalha com } \\
\text { objetivos e indicadores, porém não estabelece formas de monitoramento do plano. Na verdade, essa } \\
\text { etapa não é nem mencionada no documento. }\end{array}$ \\
\hline Observações & $\begin{array}{l}\text { Foi utilizada uma matriz para avaliação de impactos que confronta os objetivos do plano em relação aos } \\
\text { objetivos da AAE. O estudo fez boa caracterização da área e os efeitos que o turismo causa na região. } \\
\text { Trabalhar por meio de uma organização não governamental (ONG), o WWF, facilitou a consulta } \\
\text { (mediador entre grupos de interesses tão distintos). Foi destacada também a dificuldade em obter } \\
\text { informações sociais e econômicas da região. Foi firmado um termo de compromisso entre a equipe de } \\
\text { AAE e o Ministério do Turismo como forma de garantir que as recomendações da AAE sejam levadas } \\
\text { em consideracão na atualização do Plano Nacional. }\end{array}$ \\
\hline
\end{tabular}

Quadro 7. AAE do Plano de Desenvolvimento do Turismo nas Ilhas Fiji

Fonte: Levett e McNally (2003) 


\begin{tabular}{|c|c|}
\hline \multicolumn{2}{|r|}{ SEA of the Tofo, Barra, Tofinho and Rocha Beaches area, Moçambique } \\
\hline Objetivo da ação & $\begin{array}{l}\text { Ordenar a ocupação turística na zona costeira de Tofo, Barra, Tofinho e Rocha, de forma a controlar o } \\
\text { rápido crescimento da região e estabelecendo requisitos e referências para os estudos de impacto } \\
\text { ambiental de projetos (principalmente resorts, infra-estrutura e facilidades turísticas, estradas, sistemas } \\
\text { de tratamento de água e esgoto etc.). }\end{array}$ \\
\hline Quem fez & $\begin{array}{l}\text { A pedido do governo local, um órgão (Centre for Sustainable Development for Coastal Zones) ligado ao } \\
\text { Ministério do Meio Ambiente conduziu a AAE. Anterior a isso, a Agência Dinamarquesa para o } \\
\text { Desenvolvimento Internacional (DANIDA) financiou um treinamento sobre AAE, realizado por um } \\
\text { consultor externo. }\end{array}$ \\
\hline Momento de realização & AAE simultânea à elaboração do plano. \\
\hline Participação pública & $\begin{array}{l}\text { Workshops foram realizados com representantes das comunidades locais, instituições governamentais, } \\
\text { empresários e associações de turismo. Essas reuniões aconteceram em vários momentos, inclusive } \\
\text { para definição do escopo da AAE, avaliação das alternativas e para revisão do relatório final. }\end{array}$ \\
\hline Referências de sustentabilidade & $\begin{array}{l}\text { As principais referências utilizadas para análise de alternativas foram alguns objetivos e indicadores } \\
\text { ambientais, incluídos também no plano de monitoramento. }\end{array}$ \\
\hline Consideração de alternativas & $\begin{array}{l}\text { A análise de alternativas foi feita por meio de matriz de impactos (objetivos e indicadores de } \\
\text { sustentabilidade x objetivos do plano), em duas reuniões de participação, uma envolvendo especialistas } \\
\text { e membros do governo e outra com a sociedade (empresários e representantes do terceiro setor). }\end{array}$ \\
\hline Principais dificuldades & $\begin{array}{l}\text { O documento destacou o alto comprometimento das autoridades (nacionais, regionais e locais) com o } \\
\text { processo, além do amplo envolvimento das partes interessadas, ou seja, de empresários e da } \\
\text { sociedade local. O processo simultâneo facilitou a maximização da integração das questões ambientais } \\
\text { com a tomada de decisão. Foram destacadas dificuldades para chegar a um consenso referente às } \\
\text { responsabilidades institucionais (entre autoridades municipais e regionais) de licenciamento para uso do } \\
\text { solo. }\end{array}$ \\
\hline
\end{tabular}

Fonte: Dalal-Clayton e Sadler (2005) 


\section{Assessment of environmental impacts of the proposed Sectoral Operational Programme for Tourism and the Spa}

\section{Industry, República Checa}

\begin{tabular}{|ll|}
\hline Âmbito de aplicação & Programa setorial, de âmbito nacional, para o desenvolvimento da indústria do turismo (2000 - 2006). \\
\hline Objetivo da ação & $\begin{array}{l}\text { Incentivar o desenvolvimento da indústria do turismo no País mediante investimentos em diversos } \\
\text { projetos, totalizando } 100 \text { milhões de dólares em investimento. }\end{array}$ \\
\hline Quem fez & $\begin{array}{l}\text { A versão inicial do programa foi elaborada pelo Ministério do Desenvolvimento Regional com } \\
\text { participação do Ministério do Meio Ambiente. Um grupo de consultores fez a avaliação e propôs } \\
\text { mudanças. }\end{array}$ \\
\hline Momento de realização & Após a elaboração da proposta de programa. \\
\hline Participação pública & Não menciona. \\
\hline Referências de sustentabilidade & Não foram utilizadas referências de sustentabilidade. \\
\hline Consideração de alternativas & $\begin{array}{l}\text { O estudo avalia todos os objetivos do programa e propõe uma série de mudanças, que, segundo o } \\
\text { relatório foram totalmente aceitas e o programa reformulado. }\end{array}$ \\
\hline Monitoramento & A AAE propõe um sistema detalhado de monitoramento para implementação do programa. \\
\hline Observações & $\begin{array}{l}\text { A avaliação de impactos foi feita por meio de matriz (atividades propostas x fatores ambientais); porém, } \\
\text { os fatores ambientais utilizados pareciam vagos demais, dando espaço para muita subjetividade (ex. } \\
\text { impacto na população local, impacto no ecossistema etc.). Um ponto positivo da proposta é que ela } \\
\text { estabelece diversos critérios práticos para seleção e avaliação de projetos. Além disso, a equipe de } \\
\text { consultores teve que reescrever o programa, em razão do momento de realização da avaliação. As } \\
\text { propostas de revisão e mudança foram totalmente aceitas pelo Ministério responsável pela } \\
\text { implementação e monitoramento do programa. }\end{array}$ \\
\hline
\end{tabular}

Quadro 9. AAE do Programa Setorial de Turismo, República Checa

Fonte: Tichá et al. (2004) 


\begin{tabular}{|ll|}
\hline & SEA of the Varna Municipality Development Plan, Bulgaria \\
\hline Âmbito de aplicação & Plano de Desenvolvimento do Município, um centro turístico na zona costeira. \\
\hline Objetivo & $\begin{array}{l}\text { O plano tem como objetivo principal ordenar o uso e ocupação do solo, a proteção e gestão de áreas } \\
\text { naturais e a gestão de resíduos. }\end{array}$ \\
\hline Quem fez & $\begin{array}{l}\text { A AAE foi realizada por um conjunto de consultores especialistas e independentes, e é resultado de um } \\
\text { financiamento do Banco Mundial para o desenvolvimento da zona costeira búlgara. }\end{array}$ \\
\hline Momento de realização & A AAE foi realizada depois da elaboração do plano. \\
\hline Participação pública & $\begin{array}{l}\text { Foram realizadas reuniões públicas tanto pela equipe que elaborava o plano como pela equipe que } \\
\text { realizou a AAE, porém, a participação do público foi considerada muito tímida e pouco contribuiu. Além } \\
\text { disso, o público foi consultado somente na etapa final do processo, quando um rascunho da AAE já } \\
\text { estava pronto. }\end{array}$ \\
\hline Referências de sustentabilidade & Não existem. \\
\hline Consideração de alternativas & $\begin{array}{l}\text { Não houve consideração de alternativas pois a AAE limitou-se a avaliar os impactos ambientais da } \\
\text { proposta de plano já elaborada. }\end{array}$ \\
\hline Monitoramento & Não foi mencionado um plano de monitoramento. \\
\hline Observações & $\begin{array}{l}\text { A elaboração do plano e a avaliação foram realizadas por equipes diferentes e que não se consultaram. } \\
\text { Não houve tentativa de integração dos dois processos. Por esse motivo, houve duplicação de trabalhos, } \\
\text { ou seja, muitos dos elementos da AAE já tinham sido utilizados no plano (participação pública, } \\
\text { caracterização ambiental). Esse fato resultou na mudança da Lei de Avaliação de Ambiental, de forma a } \\
\text { delimitar o escopo do processo de AAE. Foi destacado também o baixo interesse do público nas } \\
\text { reuniões de consulta. A AAE utilizou apenas informações ambientais já disponíveis, que eram escassas } \\
\text { e de acesso difícil. Não fica evidente se os resultados da AAE foram considerados e se o plano passou } \\
\text { pelas mudanças necessárias. }\end{array}$ \\
\hline
\end{tabular}

Quadro 10. AAE do Plano de Desenvolvimento do Município de Varna, Bulgária

Fonte: Grigova e Metodieva (2001) e Dalal-Clayton e Sadler (2005) 
Programmatic Environmental Assessment - Tourism Facilities and Activities in the Tropics of Cochabamba, Bolívia

\begin{tabular}{|c|c|}
\hline Âmbito de aplicação & $\begin{array}{l}\text { Programa de estímulo ao turismo como alternativa econômica para a região de Chapare, na Bolívia } \\
\text { (2001). }\end{array}$ \\
\hline Objetivo da ação & $\begin{array}{l}\text { O programa de investimento em turismo está incluído num programa maior, que inclui investimentos nas } \\
\text { áreas de (agricultura, agroflorestas, gestão de florestas e infra-estrutura), como forma de estimular } \\
\text { alternativas econômicas para a região da Bolívia onde a incidência de plantações de coca é grande } \\
\text { (região de Chapare). O turismo foi identificado como uma atividade atrativa para investimentos na } \\
\text { região. }\end{array}$ \\
\hline Quem fez & $\begin{array}{l}\text { Duas empresas de consultoria internacionais, a Chemonics International Inc. e a PA Consulting Group, } \\
\text { a pedido da United States Agency for International Development (USAID). }\end{array}$ \\
\hline Momento de realização & Antes da elaboração do programa. \\
\hline Participação pública & $\begin{array}{l}\text { A participação pública foi feita em entrevistas com pessoas envolvidas no desenvolvimento da região } \\
\text { (empresários, principalmente) e algumas reuniões com membros da USAID e outros grupos de } \\
\text { interesse. O documento afirma que todas as observações feitas pelos participantes foram incorporadas } \\
\text { às alternativas analisadas. }\end{array}$ \\
\hline Referências de sustentabilidade & Não existem. \\
\hline Consideração de alternativas & $\begin{array}{l}\text { Foi feita análise de cinco cenários sobre o nível que o desenvolvimento turístico deveria atingir } \\
\text { (investimentos em larga, média ou pequena escala). Apesar de não existir um programa formal que } \\
\text { tratasse do desenvolvimento do turismo na região, já existia uma linha de investimento traçada, ou seja, } \\
\text { algumas premissas de que os investimentos seriam focados em determinadas ações. }\end{array}$ \\
\hline Monitoramento & O relatório prevê um plano de monitoramento, mas não expõe detalhes. \\
\hline Observações & $\begin{array}{l}\text { No momento da realização da avaliação, o programa de investimentos ainda não havia sido elaborado, } \\
\text { porém já haviam sido delineadas algumas premissas de que o programa iria concentrar seus } \\
\text { investimentos em algumas áreas estratégicas (infra-estrutura, planejamento local e desenvolvimento de } \\
\text { novos atrativos turísticos). O relatório traz extenso apanhado de informações referentes ao clima, } \\
\text { temperaturas, geologia e outros aspectos que poderiam ser considerados desnecessários na avaliação. } \\
\text { A avaliação de impacto das alternativas apresentadas é feita por meio de matriz (fatores ambientais x } \\
\text { atividade prevista de cada alternativa). }\end{array}$ \\
\hline
\end{tabular}

Quadro 11. Avaliação ambiental programática do turismo em Cochabamba, Bolívia

Fonte: Chemonics International (2004) 


\begin{tabular}{|c|c|}
\hline \multicolumn{2}{|r|}{ SEA of development around Victoria Falls, Zimbábue e Zâmbia } \\
\hline Objetivo da ação & $\begin{array}{l}\text { Plano de gestão para administrar o desenvolvimento ocasionado pelo aumento do turismo dentro e nos } \\
\text { arredores da área protegida de Victoria Falls, e avaliar os impactos cumulativos que esse } \\
\text { desenvolvimento pode trazer para a região, localizada na fronteira entre a Zâmbia e o Zimbábue e } \\
\text { mantida por uma gestão bilateral entre os dois países. }\end{array}$ \\
\hline Quem fez & $\begin{array}{l}\text { Representantes e especialistas de várias instituições governamentais de ambos os países. Coordenado } \\
\text { pela União Internacional para a Conservação da Natureza (IUCN) e financiado pela Agência Canadense } \\
\text { para o Desenvolvimento Internacional (CIDA). }\end{array}$ \\
\hline Participação pública & $\begin{array}{l}\text { Participação de membros e líderes de organizações comunitárias e representantes da iniciativa privada } \\
\text { de ambos os países, na forma de entrevistas e reuniões. A participação ocorreu na fase final da AAE, } \\
\text { quando o relatório já estava praticamente pronto, mais de um ano após o início dos trabalhos. Antes } \\
\text { disso, apenas especialistas de órgãos governamentais, consultores externos e membros da UICN } \\
\text { participavam das reuniões. }\end{array}$ \\
\hline Referências de sustentabilidade & Não existem. \\
\hline Consideração de alternativas & $\begin{array}{l}\text { Foram considerados quatro cenários de número de visitantes na área protegida e de pressões do } \\
\text { crescimento na região de entorno como o surgimento de infra-estrutura, ocupação do solo, mudanças } \\
\text { na paisagem, aumento de ruídos e consumo de recursos naturais etc. Na avaliação, foram utilizadas } \\
\text { matrizes de impactos. O relatório sugere um cenário de crescimento em média escala. }\end{array}$ \\
\hline Observações & $\begin{array}{l}\text { Em 1996, havia ainda pouca experiência no campo da avaliação ambiental estratégica, especialmente } \\
\text { para zonas turísticas e parques nacionais, o que explica muitas das falhas desse estudo. A divulgação } \\
\text { na mídia estimulou a participação pública, porém, seis meses depois da finalização da AAE, apenas } \\
\text { algumas recomendações haviam sido postas em prática, mas nenhuma política havia sido realmente } \\
\text { elaborada ou implementada. O ponto positivo apresentado pelo relatório foi o extenso estudo sobre de } \\
\text { caracterização ambiental da área e o levantamento dos principais problemas ambientais da região; } \\
\text { porém, pouca utilização têm esses estudos se essas informações não são incorporadas na elaboração } \\
\text { das políticas. }\end{array}$ \\
\hline
\end{tabular}

Quadro 12. AAE do Plano de Desenvolvimento de Victoria Falls, Zimbábue e Zâmbia

Fonte: Nalamino e Meynell (1997) 


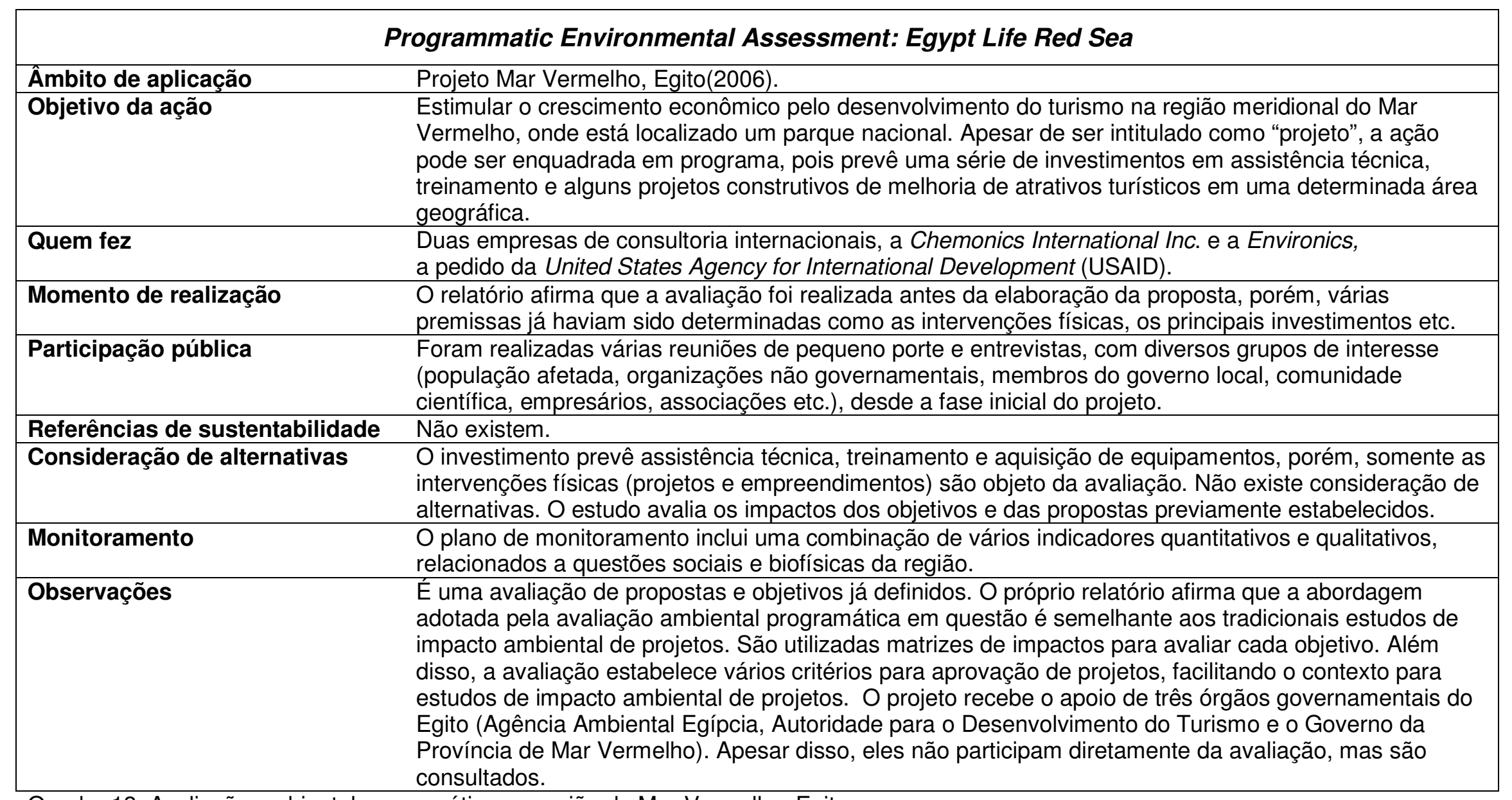

Quadro 13. Avaliação ambiental programática na região do Mar Vermelho, Egito

Fonte: Chemonics International (2006) 


\begin{tabular}{|c|c|}
\hline \multicolumn{2}{|c|}{ Strategic Environmental Assessment of the National Tourism Development Programme, Bielo-Rússia } \\
\hline Objetivo da ação & $\begin{array}{l}\text { Oferecer recomendações para atualizar e aprimorar o Programa Nacional de Desenvolvimento do } \\
\text { Turismo no País. }\end{array}$ \\
\hline Participação pública & $\begin{array}{l}\text { Foram realizadas reuniões com membros de vários ministérios, planejadores e professores } \\
\text { universitários para apresentação da versão preliminar da AAE. Além disso, foi feita divulgação (rádio, } \\
\text { internet e listas de discussões) para o público em geral sobre o processo de AAE em andamento e uma } \\
\text { reunião foi realizada durante um dia com membros de organizações não governamentais. Quem não } \\
\text { pudesse comparecer à reunião poderia enviar sugestões por e-mail. A participação do público em geral } \\
\text { foi considerada baixa. }\end{array}$ \\
\hline Monitoramento & $\begin{array}{l}\text { Foi estabelecido um conjunto de indicadores para monitoramento do plano. Não há maiores } \\
\text { detalhamentos sobre isso como responsabilidades institucionais, freqüência de avaliação etc. }\end{array}$ \\
\hline Observações & $\begin{array}{l}\text { Foi a primeira tentativa de testar e demonstrar a aplicação prática do Protocolo da UNECE. É } \\
\text { considerada uma AAE-piloto. Apesar de ter sido realizada em um momento em que boa parte do } \\
\text { programa já estava bem desenhada, a AAE sugere diversas mudanças nos objetivos do programa, } \\
\text { porém, não fica claro se essas sugestões foram realmente levadas em consideração na reformulação } \\
\text { do programa. }\end{array}$ \\
\hline
\end{tabular}

Quadro 14. AAE do Programa Nacional de Desenvolvimento do Turismo, Bielo-Rússia

Fonte: United Nations Development Programme (2005) 


\begin{tabular}{|ll|}
\hline & Strategic Environmental Assessment of the Tourism Strategy, Honduras \\
\hline Âmbito de aplicação & AAE aplicada à Estratégia Nacional de Turismo de Honduras (2004). \\
\hline Objetivo da ação & $\begin{array}{l}\text { O governo de Honduras está estimulando o turismo, com o objetivo de colocar o País no topo do } \\
\text { ranking das destinações turísticas da América Central. }\end{array}$ \\
\hline Quem fez & $\begin{array}{l}\text { Realizado pelo Banco Mundial e uma empresa de consultoria internacional, a ECON Analysis, com a } \\
\text { participação e colaboração do Instituto Hondurenho de Turismo. A AAE contou com o apoio financeiro } \\
\text { do Fundo Fiduciário Norueguês para o Desenvolvimento Sustentável. }\end{array}$ \\
\hline Momento de realização & Antes da elaboração da política. \\
\hline Participação pública & $\begin{array}{l}\text { Ministros e outros membros de funções estratégicas do governo participaram da definição do escopo da } \\
\text { AAE, em reuniões. A sociedade não foi consultada. }\end{array}$ \\
\hline Referências de sustentabilidade & $\begin{array}{l}\text { O estudo faz extensa análise sobre os impactos ambientais que o turismo já vem causando, porém é } \\
\text { pobre na base de dados e não apresenta nenhum tipo de referências, objetivos nem parâmetros de } \\
\text { sustentabilidade. }\end{array}$ \\
\hline Consideração de alternativas & $\begin{array}{l}\text { Foram elaboradas três estratégias centrais, de acordo com os possíveis cenários de crescimento do } \\
\text { turismo (baixo, moderado e acelerado). }\end{array}$ \\
\hline Monitoramento & $\begin{array}{l}\text { O estudo não menciona, em nenhum momento, a necessidade ou existência de um programa de } \\
\text { monitoramento. }\end{array}$ \\
\hline Observações & $\begin{array}{l}\text { A equipe de AAE considerou como uma dificuldade, que limitou o escopo da AAE, o fato de não haver, } \\
\text { no momento da realização da AAE, uma política nacional para o turismo. Os cenários de } \\
\text { desenvolvimento são analisados a partir de matrizes e os fatores ambientais considerados são } \\
\text { extremamente vagos (ex. consumo de água, geração de resíduos, desmatamento etc.). Na avaliação, } \\
\text { em forma de matriz, o relatório explica: "due to the limited scope of this paper, it is not practical to } \\
\text { develop these analyses in great detail'. No fim, o estudo aponta algumas recomendações para a } \\
\text { reformulação da estratégia nacional de turismo. }\end{array}$ \\
\hline
\end{tabular}

Quadro 15. AAE da Estratégia Nacional de Turismo, Honduras

Fonte: Econ Analysis (2004) 


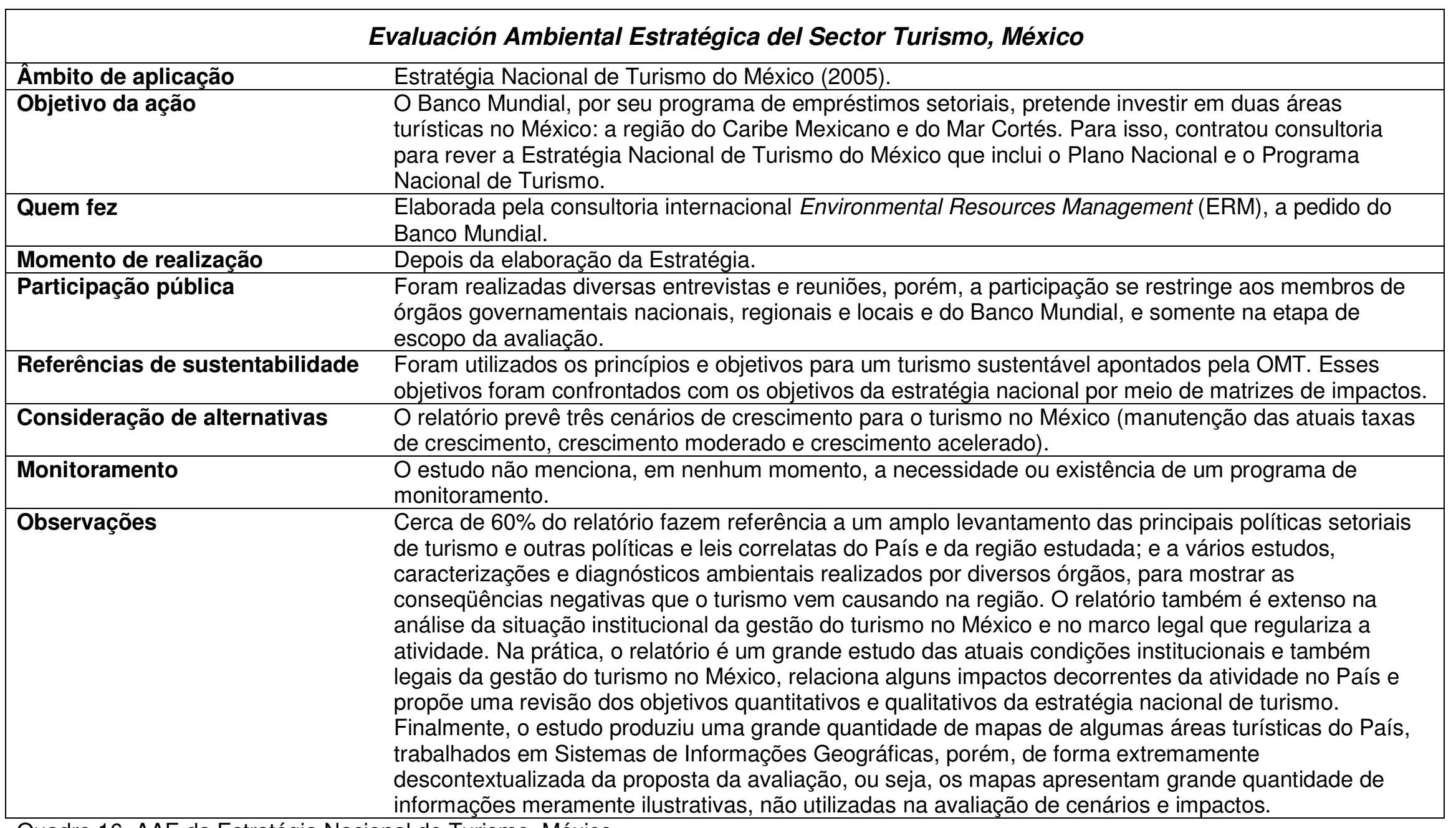

Quadro 16. AAE da Estratégia Nacional de Turismo, México

Fonte: Environmental Resources Management (2005) 


\begin{tabular}{|c|c|}
\hline \multicolumn{2}{|r|}{ SEA Pilot Project of the Oymapınar Tourism Development Plan, Turquia } \\
\hline Objetivo da ação & $\begin{array}{l}\text { Experiência-piloto de aplicação da AAE na Turquia, de forma a se adequar à legislação da União } \\
\text { Européia. O plano tem como objetivo diversificar os atrativos turísticos, melhorar a qualidade dos } \\
\text { serviços prestados, fornecer melhores contextos e oportunidades para investimentos privados, } \\
\text { aumentar o fluxo de visitantes e o tempo médio de permanência na região. }\end{array}$ \\
\hline Quem fez & Um grupo formado por vários representantes dos Ministérios do Meio Ambiente e do Turismo. \\
\hline Momento de realização & Antes da elaboração do plano. \\
\hline Referências de sustentabilidade & Não existem. \\
\hline Consideração de alternativas & $\begin{array}{l}\text { Duas alternativas são analisadas: a não-ação, ou seja, a região deve continuar como está ou o } \\
\text { desenvolvimento turístico intenso e a realização dos investimentos previstos. }\end{array}$ \\
\hline Monitoramento & O relatório não menciona nenhum plano de monitoramento. \\
\hline Observações & $\begin{array}{l}\text { Mais de } 50 \% \text { do relatório são compostos por estudos de caracterização de solo, clima, vegetação, } \\
\text { fauna, aspectos históricos e culturais da região, pouco utilizados na avaliação de impactos e de } \\
\text { alternativas ao plano. Não existe uma metodologia específica para avaliação de impactos. Eles são } \\
\text { simplesmente descritos de uma forma geral e sucinta. Apesar de o relatório afirmar que não existe um } \\
\text { plano definido e aprovado para a área, no momento da realização da AAE, já havia a previsão de uma } \\
\text { série de investimentos privados para a área e a intenção de desenvolver uma série de projetos turísticos } \\
\text { na região. }\end{array}$ \\
\hline
\end{tabular}

Quadro 17. AAE do Plano de Desenvolvimento do Turismo em Oymapinar, Turquia

Fonte: Republic of Turkey Ministry of Environment and Forestry (2006) 


\begin{tabular}{|c|c|}
\hline \multicolumn{2}{|c|}{ Orientations for the sustainability of European Tourism: Extended Impact Assessment } \\
\hline Objetivo & $\begin{array}{l}\text { O estudo estabelece orientaç̃̃es estratégicas comuns para os países da União Européia, em busca de } \\
\text { formas mais sustentáveis de turismo. É um estudo preliminar para uma futura política de turismo para a } \\
\text { União Européia. }\end{array}$ \\
\hline Quem fez & Grupo de trabalho da União Européia. \\
\hline Momento de realização & Antes da elaboração da política. \\
\hline Participação pública & $\begin{array}{l}\text { Um rascunho do documento final ficou disponível na internet durante três meses para envio de } \\
\text { comentários de possíveis grupos de interesse. Esses comentários estão anexados no documento final } \\
\text { da AAE. }\end{array}$ \\
\hline Referências de sustentabilidade & $\begin{array}{l}\text { São estabelecidos alguns objetivos, extraídos de outros documentos, estratégias e políticas } \\
\text { relacionados ao turismo, e utilizados como referência para a elaboração da política. }\end{array}$ \\
\hline Consideração de alternativas & $\begin{array}{l}\text { São analisadas quatro possíveis alternativas, inclusive um cenário de não-ação. Os critérios analisados, } \\
\text { porém, são muito mais relacionados à viabilidade política e institucional da alternativa do que às } \\
\text { questões ambientais propriamente ditas. Duas alternativas foram excluídas logo no início, uma por falta } \\
\text { de apoio político e a outra por ser incompatível com a política de sustentabilidade adotada pela União } \\
\text { Européia. É um típico caso em que a AAE se transforma no próprio processo decisório, ou seja, o } \\
\text { estudo é apresentado de forma a justificar a adoção de determinada alternativa. }\end{array}$ \\
\hline Observações & $\begin{array}{l}\text { A avaliação de impacto foi realizada por meio de análise multicriterial, comparando vários critérios de } \\
\text { análise (objetivos de sustentabilidade) com as alternativas apresentadas. Os critérios utilizados são } \\
\text { todos de caráter qualitativo e extremamente vagos e subjetivos como "respeito à capacidade de carga } \\
\text { ambiental" ou "bem-estar das comunidades locais", e não são detalhados na forma de indicadores. }\end{array}$ \\
\hline
\end{tabular}




\subsection{Análise dos estudos de caso}

A seguir são discutidos os principais resultados das análises feitas sobre a experiência prática internacional de avaliações ambientais estratégicas para o setor de turismo.

Os estudos analisados contemplam países das mais diversas partes, a maioria, porém, de nações em desenvolvimento ou em processo de transição. As metodologias, abordagens e âmbito de aplicação variam consideravelmente, refletindo as diferenças políticas, econômicas e institucionais desses países. Ao todo, foram 14 estudos de caso e o quadro 19 relaciona esses números com os países onde as AAEs foram realizadas. 


\begin{tabular}{lc}
\hline \multicolumn{1}{c}{ Regiões } & Número de AAEs \\
\hline Europa & $\mathbf{1}$ \\
República Checa & $\mathbf{1}$ \\
Bielo-Rússia & $\mathbf{1}$ \\
Bulgária & $\mathbf{1}$ \\
Turquia & $\mathbf{1}$ \\
União Européia & 3 \\
África & $\mathbf{1}$ \\
Moçambique & $\mathbf{1}$ \\
Zimbábue e Zâmbia & $\mathbf{1}$ \\
Egito & 3 \\
América Latina & $\mathbf{1}$ \\
Bolívia & $\mathbf{1}$ \\
Honduras & $\mathbf{1}$ \\
México & $\mathbf{1}$ \\
Oceania & $\mathbf{1}$ \\
Ilhas Fiji & $\mathbf{1}$ \\
Reino de Tonga & América do Norte \\
Canadá & \\
\hline Quadro 19. Localização dos estudos de caso analisados
\end{tabular}

Na Europa, destaca-se a predominância de países do Leste Europeu. Apesar de a Diretiva Européia exigir a realização de avaliação ambiental de planos e programas de turismo, a ocorrência efetiva dessas AAEs é praticamente inexistente e isso decorre de vários fatores.

O turismo envolve uma multiplicidade de atores e setores econômicos e sociais muito grande. Isso significa que ele pode ser gerido e regulado por meio de outros tipos de políticas setoriais, como políticas de uso e ocupação do solo, desenvolvimento econômico, estímulo à cultura, gestão de áreas costeiras, inclusão 
social etc., dependendo do status político e econômico e do perfil da atividade em cada local ou região.

Além disso, a Diretiva Européia determina que, além do fato de o plano ou programa se enquadrar dentre as atividades citadas, ele deve ser necessariamente sujeito à apreciação legislativa, regulatória ou administrativa. E muitos planos e programas de turismo não chegam a esse ponto. Isso porque esse requisito, segundo D'leteren (2006), contraria uma tendência muito presente na maioria dos países desenvolvidos, em que o Estado se desliga cada vez mais do processo de regulação da atividade turística, principalmente por conta de fortes pressões do setor empresarial em favor da auto-regulação.

Essa afirmação é confirmada pelo caso da avaliação de impacto da estratégia de turismo da União Européia, em que a decisão de abandonar a formulação de uma política de turismo para a União Européia foi influenciada, principalmente, porque o setor empresarial europeu foi fortemente contra a sua aprovação pelo receio de que a intervenção do Estado, mediante uma política de turismo, possa significar uma tentativa de controlar o setor. No caso em foco, em vez de apostar numa política de turismo, a União Européia escolheu reforçar a estrutura já existente, ou seja, aumentar a influência que outras políticas (uso do solo, recursos hídricos, transportes etc.) exercem sobre o setor, otimizando a busca de formas mais sustentáveis de turismo.

Outro motivo que explica esses números é a importância econômica que o turismo representa em países em desenvolvimento em relação a outras atividades. Em alguns casos, como o das Ilhas Fiji e do Reino de Tonga, o turismo representa o principal fator de entrada de divisas e de investimentos externos e de criação de empregos. Some-se a isso o fato de que esses mesmos países ainda apresentam 
extensões de áreas selvagens, intocadas e de grande atratividade turística a explorar. Muitos também carecem de sistemas legais e regulatórios efetivos que evitem os principais impactos ambientais e sociais resultantes do turismo.

Os países em desenvolvimento também são alvo de muitos programas de investimento de agências bi e multilaterais de desenvolvimento e que incentivam ou exigido avaliações ambientais estratégicas de suas ações de financiamento, como é o caso de várias experiências analisadas aqui.

Entende-se que o fato de a maioria dos estudos ser proveniente de países em desenvolvimento ou em transição, como os países do Leste Europeu, não desmerece a importância desses estudos, pois eles podem trazer boas lições para o Brasil, visto que muitos dos problemas e limitações desses países são semelhantes à realidade daqui.

\subsection{1 Âmbito de aplicação}

Em relação ao âmbito de aplicação das AAEs, é possível constatar, conforme mostra o quadro 20 , que a maior parte das experiências está relacionada à avaliação de planos e programas.

\begin{tabular}{lc}
\hline \multicolumn{1}{c}{ Âmbito de aplicação } & Número de AAEs \\
\hline Política / Estratégia & 3 \\
Plano & 6 \\
Programa & 5 \\
\hline Quadro 20. Âmbito de aplicação dos estudos de caso de AAE de turismo
\end{tabular}


Os programas de estímulo ao turismo são mais comuns e, geralmente, estão relacionados a uma estratégia de diversificação da oferta ou melhoria de infraestrutura e atrativos turísticos, num contexto de vários projetos para uma determinada região geográfica. Quando dissociados de outras estratégias (políticas e planos) que também tenham sido sujeitas à $A A E$, essas experiências parecem contribuir muito pouco para garantir formas menos impactantes de turismo, isso porque, raramente, elas são capazes de avaliar impactos cumulativos e partem do princípio de que estimular o turismo é a melhor opção, ou seja, não há reflexão sobre outras possíveis formas de desenvolvimento, já que essas questões são tratadas em níveis mais estratégicos. O lado positivo é que, nesses casos, geralmente, a avaliação estabelece critérios práticos a serem seguidos no planejamento e avaliação de projetos, como de fato ocorreu nos casos do Programa Setorial de Estímulo ao Turismo no Canadá e o Programa de Desenvolvimento do Turismo na República Checa.

Os planos podem se apresentar de várias formas. Em alguns casos, eles se aproximam mais de uma abordagem política, com orientações estratégicas com vistas à sustentabilidade da atividade, como é o caso das Ilhas Fiji; em outras situações, trazem considerações e abordagens mais práticas, com objetivos voltados para a ação, como é o caso de Moçambique, da cidade de Neiafu, e da Turquia, sendo os dois últimos muito próximos do conceito de programa.

O caso que mais se aproxima da abordagem de política é o da União Européia, em que são discutidas várias questões conceituais relacionadas à operacionalização do conceito de turismo sustentável. Os casos de Honduras e do México foram intitulados "estratégias" nacionais, mas nem por isso se pode dizer que são políticas, pois se assemelham à abordagem utilizada em planos nacionais. 
Esses casos apenas confirmam o que já foi expresso sobre as definições de políticas, planos e programas. Essas nomenclaturas significam coisas distintas, dependendo de cada contexto político e institucional.

\subsubsection{Momento de realização}

A maior parte das avaliações foi realizada antes ou depois da elaboração da ação estratégica, conforme mostra o quadro 21.

\begin{tabular}{lc}
\hline Momento de realização & Número de AAEs \\
\hline Antes & 7 \\
Durante & 3 \\
Depois & 4 \\
\hline Quadro 21. Momento de realização das AAEs de Turismo
\end{tabular}

Nos casos de avaliação posterior à elaboração da proposta, a AAE funciona como um instrumento de avaliação de impacto de propostas já elaboradas e muitas vezes não fica muito claro se as considerações e sugestões feitas no relatório da AAE serão realmente levadas em consideração para modificar a política em questão.

Por outro lado, o que se entende aqui como AAE não é uma avaliação de objetivos preconcebidos, mas um instrumento de auxílio à elaboração desses objetivos. Defende-se aqui, portanto, uma abordagem mais proativa da AAE, de forma que ela contribua para a formulação e desenvolvimento dos objetivos 
estratégicos dessas políticas e não se restrinja simplesmente a avaliar os impactos de propostas já formuladas.

Além disso, o caso da Turquia e de Victoria Falls mostrou que realizar a AAE antes da elaboração do plano, e não de forma concomitante, pode ser tão problemático quanto realizá-la depois. Em nenhuma das situações, é possível garantir que as considerações da AAE serão incorporadas na formulação da ação proposta. Por fim, pouca utilização têm esses estudos se essas informações não são incorporadas na elaboração das políticas. Acredita-se, portanto, que a única forma de aumentar as chances de a $A A E$ ser realmente um instrumento de auxílio à formulação de políticas mais sustentáveis é incorporar os dois processos no mesmo momento e fazer as equipes conversarem e participarem dos dois processos.

No caso de Cochabamba, na Bolívia, a equipe responsável pela AAE destacou no relatório que o fato de não haver um programa de investimentos já elaborado diminuiu e limitou os trabalhos da avaliação. Isso decorre do fato de que muitos avaliadores ainda seguem os modelos tradicionais de avaliação de impacto de propostas já formuladas. Nesse caso, a avaliação realizada no início do processo de planejamento poderia fornecer oportunidades para que os avaliadores sugerissem melhores caminhos, estratégias e alternativas a serem tomados, realmente auxiliando na constituição do programa. Essa oportunidade, no entanto, não foi aproveitada.

Por isso, pode-se concluir que, mesmo que AAE seja adotada no início do planejamento, esse fato não significa necessariamente que ela seja capaz de influenciar na adoção de alternativas de desenvolvimento mais sustentáveis, pois isso vai depender de outros fatores, principalmente do contexto político e 
institucional, das formas de participação da sociedade e das pessoas envolvidas e também responsáveis pela avaliação.

\subsubsection{Participação}

A participação da sociedade na avaliação ambiental estratégica pode tomar diversas formas, envolver vários segmentos da sociedade e ocorrer em diferentes momentos. Dos casos analisados, pode-se considerar que houve algum tipo de participação da sociedade em nove avaliações, quatro não realizaram nenhum tipo de consulta ou abriram qualquer espaço para opiniões externas, e, em um caso, o do México, a equipe responsável pela AAE considera como "participação da sociedade" as entrevistas e reuniões realizadas com membros do governo.

A participação nesses casos ocorreu principalmente em reuniões, workshops, envio de observações e sugestões pela internet e até entrevistas.

As entrevistas individuais são comuns nos casos em que a AAE é realizada por consultorias internacionais, a pedido de agências bi e multilaterais de desenvolvimento (casos da Bolívia, México e Egito). Em nenhum dos casos, as entrevistas são transcritas na $A A E$ e não fica evidente de que forma foram selecionados os entrevistados, que observações ou contribuições foram feitas e se

foram incorporadas à $A A E$. É questionável se essas entrevistas podem realmente ser consideradas uma forma efetiva e democrática de participação, já que se restringe a um limitado número de pessoas, previamente selecionadas pela equipe responsável pela $\mathrm{AAE}$.

O momento em que a sociedade é ouvida também varia bastante. Em várias experiências, a participação só é possível quando um rascunho da AAE já está 
pronto. O caso de Moçambique é um raro exemplo em que diversas reuniões foram realizadas com alguns grupos de interesse, desde a fase de determinação do escopo da AAE, até a avaliação de alternativas e a revisão do relatório final.

Nos casos da Bielo-Rússia e da Bulgária, as equipes responsáveis pela realização da $A A E$ decidiram que a participação da sociedade só aconteceria quando um rascunho da $A A E$ já estivesse pronto. $O$ documento da $A A E$ da BieloRússia diz: "A equipe responsável decidiu que seria mais eficaz realizar consultas apenas quando um primeiro rascunho do relatório de AAE estivesse pronto". Em ambos os casos, isso ocasionou grande desinteresse por parte do público, com poucas manifestações e contribuições.

No caso da Bielo-Rússia, os comentários do público estão reunidos nos anexos da AAE e o documento explica por que algumas sugestões foram levadas em consideração e outras não. Esse é um caso raro, pois, na maioria das AAEs, não fica claro como a participação do público contribuiu ou se suas observações foram incorporadas à AAE. Em outros exemplos os comentários do público se transformam em anexo da AAE e acabam por não ocasionar mudanças significativas na proposta. Essa forma de participação é corrente na maioria das avaliações analisadas e se resume a um momento de abertura para informar ao público sobre a AAE.

\subsubsection{Responsabilidade pela condução da AAE}

Algumas experiências mostram organizações não governamentais coordenando, mediando e até financiando avaliações ambientais estratégicas em países em desenvolvimento. No caso das Ilhas Fiji, isso foi considerado um ponto 
extremamente positivo no momento em que trabalhar mediado por uma ONG (WWF) facilitou a consulta, em que o WWF representou o papel de instituição imparcial e pôde mediar conflitos entre grupos de interesses tão distintos. O mesmo ocorreu na área de Victoria Falls, em que a AAE foi fruto de iniciativa da IUCN. Geralmente essas organizações se utilizam de consultores internacionais e firmam termos de compromisso com os órgãos governamentais responsáveis pela implementação das ações estratégicas. Em todos os casos, esses acordos firmados entre ONGs e governos não parecem garantir que as sugestões apontadas pelos relatórios da $A A E$ serão realmente incorporadas às políticas e, muito menos, postas em prática.

A utilização de uma consultoria externa pode ser positiva no momento em que traz para a equipe pessoas capacitadas e, acima de tudo, imparciais. Se, porém, os responsáveis pela tomada de decisão e a instituição propositora da política não participarem de forma ativa no processo, fica mais difícil garantir que os resultados e as recomendações da $\mathrm{AAE}$ sejam realmente levados em consideração. Além disso, a distância entre consultores externos e os membros do governo tomadores de decisão faz com que muitas das recomendações propostas nessas AAEs estejam muito longe da realidade e da capacidade institucional e política dos órgãos governamentais responsáveis pela implementação das ações. Nesses casos, correse o risco de a AAE se transformar num estudo de gaveta.

Outro problema identificado nesses casos, em que o governo local pouco participa da avaliação, é que o processo de $A A E$ raramente leva em consideração outras políticas, planos e programas já em curso, ou seja, está totalmente dissociado de outras estratégias estabelecidas para a região ou para o setor avaliado.

No caso das Ilhas Fiji, em que se optou por firmar um termo de compromisso entre a instituição responsável pela AAE e o Ministério do Turismo, apenas um 
representante do governo participou da equipe responsável pela AAE. Se, porém, pretende-se utilizar a AAE como um instrumento de auxílio à formulação de políticas, considera-se indispensável que as pessoas responsáveis pelo planejamento e tomada de decisão dessas políticas participem de forma ativa da avaliação ambiental estratégica. Além disso, nesses casos, surge uma situação inusitada em que o órgão responsável pela implementação e monitoramento da proposta não participou das discussões e da sua elaboração. Nesses casos, certamente um trabalho em equipe teria mais chances de sucesso.

\subsubsection{Aspectos metodológicos}

Ainda não é muito comum a utilização de objetivos e indicadores ambientais como referências de sustentabilidade na avaliação ambiental estratégica de políticas, planos e programas de turismo. Em poucos casos, foram desenvolvidos objetivos e indicadores próprios para cada realidade. Somente as AAEs das Ilhas Fiji e de Moçambique utilizaram essa metodologia de maneira coerente. Em outros casos, como no México e em Honduras, apenas alguns poucos objetivos foram levantados para serem confrontados com o os objetivos dos planos em questão, porém, eram extremamente vagos ou não foram desenvolvidos de acordo com a realidade local. No México, foram utilizados os objetivos para um turismo sustentável apontados pela OMT.

As demais experiências ignoram a utilização de qualquer tipo de referência de sustentabilidade. Essa ausência pode ser responsável por boa parte das falhas desses estudos e ocasiona uma série de conseqüências negativas. Uma delas é na fase de levantamento da base ambiental. Em vários casos (especialmente Bolívia, 
México e Turquia), a base ambiental se traduz num extenso apanhado de informações desconexas e desnecessárias. A utilização de objetivos e indicadores poderia auxiliar no levantamento de informações que realmente interessam na avaliação de impacto do turismo, ou seja, a manter o foco da avaliação em temas e questões-chave.

A AAE do México é emblemática, pois cerca de $60 \%$ do relatório faz referência a um amplo levantamento das principais políticas setoriais de turismo e a vários estudos, caracterizações e diagnósticos ambientais realizados por diversos órgãos. O estudo produziu grande quantidade de mapas, trabalhados em sistemas de informações geográficas, porém, de forma extremamente descontextualizada da proposta da avaliação, ou seja, os mapas apresentam grande quantidade de informações meramente ilustrativas, não utilizadas na avaliação de cenários e impactos.

O exemplo da Turquia é outro em que mais de $50 \%$ do relatório são compostos por estudos de caracterização de solo, clima, vegetação, fauna, aspectos históricos e culturais da região, pouco utilizados na avaliação em si.

Além disso, a ausência de objetivos e indicadores tem conseqüência direta no monitoramento. Na maioria, essa etapa é negligenciada e possíveis objetivos e indicadores levantados previamente poderiam ser extremamente úteis para avaliação e acompanhamento da implementação do plano ou programa. Em outros casos, a AAE reconhece a necessidade de ações de monitoramento, porém, geralmente são apresentadas na forma de uma intenção futura ou de forma superficial, como é o caso da Bolívia, do Canadá e de Victoria Falls (Zâmbia e Zimbábue). 
Outra conseqüência da falta de objetivos e indicadores são as formas de avaliação de impactos das alternativas. Os métodos qualitativos são preponderantes em praticamente todas as avaliações analisadas, especialmente as listagens de controle, geralmente apresentadas de modo mais simples, identificando os principais impactos das alternativas analisadas; e as matrizes de impactos, que comparam as alternativas previstas com alguns fatores ambientais. Em dois casos, foram utilizados uma análise multicriterial e a superposição de cartas mediante sistema de informações geográficas, porém, sem objetivos e indicadores bem definidos, essas análises são extremamente superficiais. Os objetivos do plano são confrontados com objetivos e/ou aspectos ambientais vagos e insuficientes.

No caso do Egito, a matriz de impactos não menciona os impactos de ocorrência mais freqüente quando se trata de turismo, como as conseqüências à fauna e flora da região, aumento da geração de resíduos e consumo de água e energia etc. São impactos não relacionados diretamente com o objetivo do plano, mas são efeitos indiretos dos investimentos em infra-estrutura e, conseqüentemente, do aumento da visitação às áreas naturais.

\subsubsection{Considerações gerais}

Já foram destacadas aqui as principais falhas no que se refere à participação da sociedade, aos aspectos metodológicos, âmbitos de aplicação e responsabilidades institucionais.

É claro que esses exemplos representam apenas uma parte do que já se fez. Além disso, a AAE aplicada ao setor de turismo ainda carece de mais 
experimentação e é possível que, com o tempo e as lições aprendidas, essas experiências possam ser aperfeiçoadas.

A partir das análises feitas, é importante ressaltar aqui que esses estudos ainda carecem de abordagens mais estratégicas e aprofundadas sobre o turismo e suas conseqüências ambientais. O turismo ainda é estimulado de forma negligente e nenhum estudo analisado avalia o impacto do estímulo ao turismo em relação a outras atividades econômicas. Quando se trata de um plano de incentivo ao turismo, ele já parte de várias premissas e idéias preconcebidas de que o turismo é uma boa alternativa econômica para a área. Nesses casos, opta-se por uma abordagem de cenários, com análise de tipos e níveis diferentes de desenvolvimento turístico.

Já no programa, essa análise de cenários talvez não seja apropriada quando avaliações foram feitas em etapas anteriores (políticas e planos), pois essas questões mais estratégicas já foram discutidas e avaliadas. O programa, geralmente, constitui uma série de projetos (ver caso do Canadá) e freqüentemente esses programas já estabelecem informações detalhadas em relação a tipologia e localização de projetos. Por tal motivo, essas avaliações são as que mais se aproximam das avaliações de projetos.

O problema é que a $\mathrm{AAE}$ ainda não é adotada de forma ampla em todos os níveis de planejamento (PPPs). O caso do Canadá é o único em que essa relação entre diferentes seqüências de planejamento fica bem clara e é um bom exemplo de como AAEs nos vários níveis de planejamento estratégicos podem se influenciar e estabelecer melhores contextos para o nível seguinte; ou seja, as premissas e os objetivos adotados no programa estão vinculados a outras ações estratégicas avaliadas anteriormente. Já no caso do Egito, o programa de investimentos da USAID não está vinculado - pelo menos não é mencionado no relatório - a nenhum 
outro plano ou política de investimentos para a área ou para o setor de turismo. Isso faz com que seja questionável o quão "sustentáveis" são os objetivos e premissas estabelecidos pelo programa.

Nesses casos, é imprescindível avaliar as conseqüências que o estímulo ao turismo pode causar no ambiente local. Um bom exemplo de como essa abordagem pode ser utilizada, no plano municipal ou de pequenas localidades turísticas, é a experiência dos modelos ingleses (Local Development Plans) de planejamento, que estabelecem políticas e propostas de longo prazo para guiar o desenvolvimento local. No Brasil, é possível que outros instrumentos de planejamento, como o Plano Diretor, consigam trazer respostas para esse tipo de problema.

No caso do Egito, partiu-se do princípio de que o turismo traria uma série de benefícios para a economia local, porém, o próprio relatório reconhece vários fatores limitantes da atividade, como problemas de escassez de água e carência pessoal, institucional e operacional para gestão de uma área natural protegida, conseqüentemente, imprópria para receber visitantes. Mesmo assim, o estudo se restringiu a identificar os impactos diretos que alguns projetos construtivos ocasionariam no interior do parque.

Em outras AAEs (Fiji e Varna), a equipe responsável destacou a inexistência ou escassez de informações ambientais como um dos principais problemas. Geralmente, não existe tempo hábil para que se produza informação ambiental suficiente e aquelas disponíveis são insuficientes. Em outros casos (Turquia, Bolívia e Egito), em que essas informações são mais detalhadas ou até extensivas demais, parece não haver razão que justifique um apanhado tão grande de informações, pois a maioria não é relevante ao que está sendo analisado, simplesmente não é utilizada na avaliação de impactos ou não é incorporada ao plano (informações 
climáticas, caracterização de vegetação, fauna, solos etc.). Mais uma vez, esses equívocos são resultado de falhas na metodologia utilizada, como mencionado em passagem anterior do presente trabalho.

O caso de Honduras é um típico exemplo de relatório de diagnóstico intitulado de AAE. As análises de impacto são extremamente superficiais, a avaliação não ocorre de forma integrada com o planejamento e formulação da política e, por isso, não influencia a tomada de decisão. É perigoso quando se intitulam esses estudos de avaliação ambiental estratégica, pois isso desvirtua a verdadeira proposta do instrumento e essas atitudes é que podem colocar a AAE em descrédito.

Os estudos fazem caracterizações superficiais ou entram em detalhes em aspectos ambientais totalmente desnecessários e desvinculados da atividade turística.

Assim, é possível identificar muitos desses estudos como o que Dalal-Clayton e Sadler (2005) classificam como Para-SEA, ou seja, não atendem necessariamente a todos os requisitos do que se entende por $\mathrm{AAE}$, mas apresentam muitas de suas características.

De maneira geral, portanto, esses "exercícios" de AAE e turismo ainda apresentam muitas falhas e pode-se afirmar que ainda falta um longo caminho para que a aplicação desse instrumento alcance resultados coerentes e consiga realmente influenciar a elaboração de políticas, planos e programas de turismo mais sustentáveis. 


\section{ESTUDO DE CASO}

O presente capítulo apresenta um estudo de caso realizado no Município de Bueno Brandão, localizado no Estado de Minas Gerais, com o intuito de, a partir das informações obtidas em campo, oferecer subsídios e recomendações para uma possível aplicação da avaliação ambiental estratégica em um plano de desenvolvimento turístico.

A escolha pelo Município de Bueno Brandão para a análise deste estudo ocorreu por duas principais causas. A primeira delas diz respeito ao fato de Bueno Brandão está inserida numa região considerada estratégica, abrigo de grande parte das nascentes e dos mananciais que formam o rio Mogi-Guaçu e, por essa razão, passou a ser objeto de estudo e intervenção do Núcleo de Estudos de Ecossistemas Aquáticos, do Departamento de Hidráulica e Saneamento, da Escola de Engenharia de São Carlos, com patrocínio do Programa Petrobrás Ambiental. Além disso, o desenvolvimento do turismo no Município ainda pode ser identificado como de estágio inicial e com grande potencial de crescimento, o que foi considerado propício para o estudo em questão.

\subsection{Apresentação da área de estudo}

A bacia hidrográfica do Mogi Guaçu abrange um total de 48 municípios, envolvendo áreas territoriais dos Estados de São Paulo e Minas Gerais, e é caracterizada por sua diversidade em termos de processos históricos de ocupação, de exploração agrícola e de crescimento urbano e populacional. Apesar desta 
diversidade, pode-se afirmar que tanto sua dinâmica econômica quanto demográfica refletem o processo recente de interiorização da indústria e de intensa modernização e ganhos de produtividade da agropecuária estadual (COMITÊ DA BACIA HIDROGRÁFICA DO RIO MOGI GUAÇU, 1999).

Como conseqüência da ocupação intensa, vários problemas ambientais e alterações na qualidade da água já podem ser observadas na região. Apesar de estar, em grande parte de sua extensão, no Estado de São Paulo, o rio Mogi Guaçu tem suas nascentes localizadas no Estado de Minas Gerais e, segundo Brigante e Espíndola (2003), os impactos ambientais dessa bacia são mais preocupantes na região de montante (em destaque na figura 10), onde os cursos d'água têm sido submetidos a diversos impactos ecológicos ocasionados pelas atividades antrópicas, especialmente as produções agrícolas e pastoris, gerando efeitos e reflexos ambientais negativos sobre os recursos naturais e hídricos da região. 


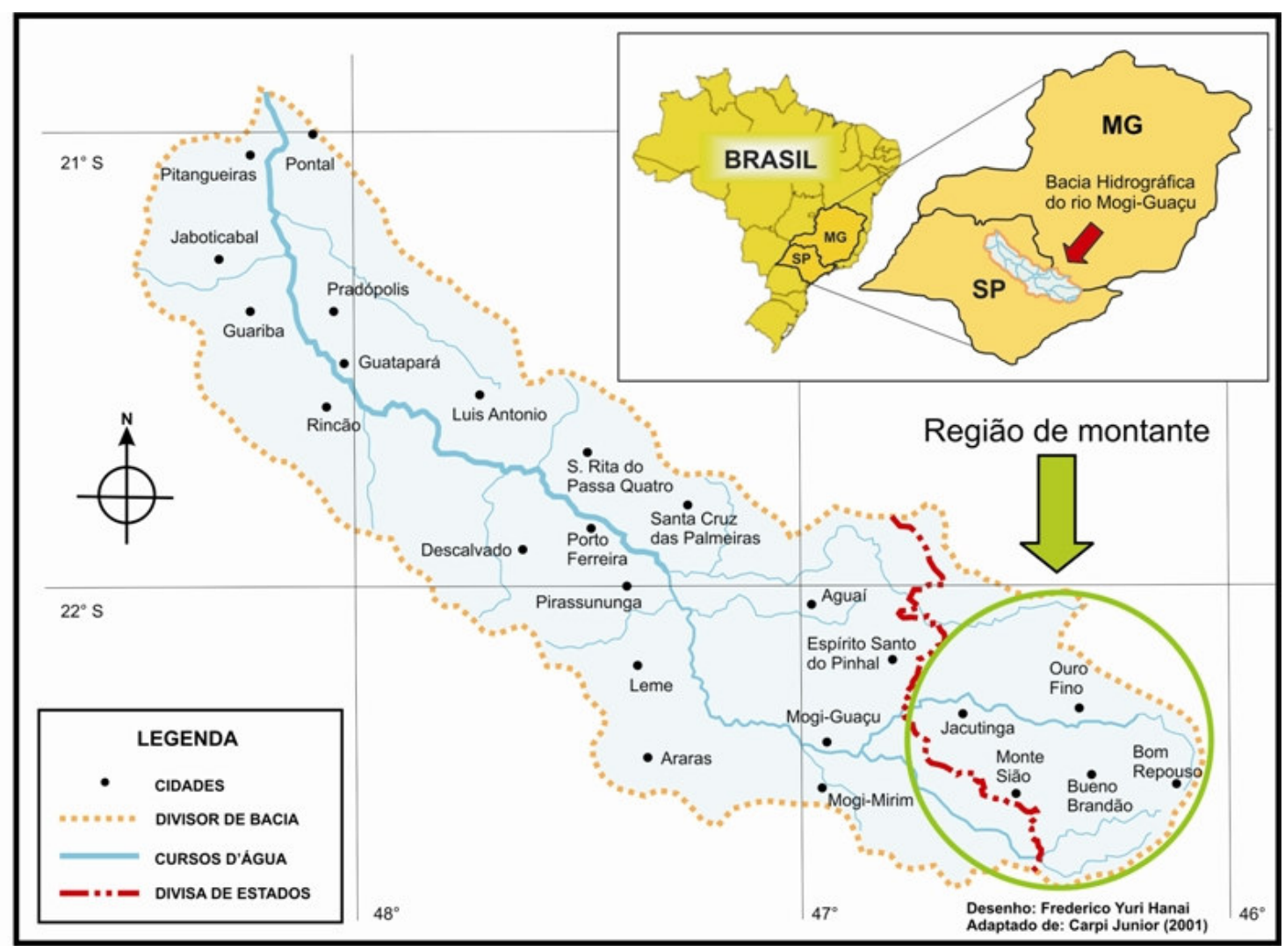

Figura 10. Localização dos municípios da região de montante da Bacia Hidrográfica do rio Mogi-Guaçu

Fonte: Adaptado de Carpi Júnior (2001)

Por essa razão, as questões de conflito, que originaram os principais impactos ambientais observados na região de montante do Mogi-Guaçu, passaram a ser objeto de estudo e intervenção do Núcleo de Estudos de Ecossistemas Aquáticos, do Departamento de Hidráulica e Saneamento, da Escola de Engenharia de São Carlos, com patrocínio do Programa Petrobrás Ambiental, com o intuito de promover ações capazes de auxiliar a redução dos impactos antrópicos nessa região, redirecionando o uso e manejo dos recursos hídricos existentes e interferindo nos aspectos sociais (educação ambiental) e econômicos (agricultura, piscicultura e turismo) da região. 
Os municípios da região estratégica de montante da bacia do Mogi Guaçu têm como base econômica as atividades rurais (agrícolas e pecuárias) e de produção de malhas (confecções, vestuário). A situação de dependência em relação a esses setores econômicos tem se mostrado insuficiente e limitada para a manutenção da qualidade de vida das comunidades locais. A equipe do Projeto Mogi-Guaçu, portanto, estabeleceu como uma de suas linhas de ação, o estímulo à criação de estratégias que propiciem oportunidades alternativas de desenvolvimento, conciliáveis com a conservação dos recursos naturais (HANAI, ESPÍNDOLA e BRIGANTE, 2007).

Dentre essas estratégias, o turismo emergiu como atividade potencialmente atrativa no que se refere ao desenvolvimento de alternativas econômicas aliadas ao comprometido com a conservação dos recursos naturais.

Visitas iniciais à região, realizadas pela equipe do Projeto Mogi Guaçu, mostraram que alguns municípios possuem necessidade urgente de opção alternativa de desenvolvimento associado ao turismo (casos de Bom Repouso-MG e de Jacutinga-MG), sendo que o município de Bueno Brandão-MG já vem promovendo o desenvolvimento turístico, porém, necessitando de orientações para organização e planejamento da atividade. Outros municípios, apesar de possuírem recursos turísticos, necessitam de estrutura institucional para início das ações de desenvolvimento de turismo. Os demais municípios possuem tradição turística com turismo organizado e estabelecido (Lindóia, Águas de Lindóia, Socorro, Serra Negra, Monte Sião), não priorizando a necessidade das ações propostas pelo Núcleo de Turismo (HANAI, ESPÍNDOLA E BRIGANTE, 2007).

O Município de Bueno Brandão, portanto, se destaca por já apresentar certo grau de desenvolvimento relacionado a atividades turísticas, ainda carecendo, 
porém, de ações de planejamento e investimento para o setor. Com o intuito de auxiliar o desenvolvimento e consolidação de um turismo mais responsável no município de Bueno Brandão-MG, a equipe responsável pelo Projeto Mogi-Guaçu estabeleceu algumas ações estratégicas baseadas nas necessidades locais do município. São elas:

- a análise do potencial de desenvolvimento turístico de Bueno Brandão (levantamento de atrativos e cadastro e avaliação dos empreendimentos turísticos existentes);

- a identificação do perfil da população local, moradores e produtores rurais (ver figuras 11 e 12);

- a identificação e caracterização da demanda turística, realizadas com pesquisa aos visitantes da região (suas preferências e motivações de viagens e avaliação sobre as condições de visitação na região) e;

- a elaboração de instrumentos e procedimentos para analisar as condições e o processo de desenvolvimento turístico na região, como parte de pesquisa de doutoramento. 

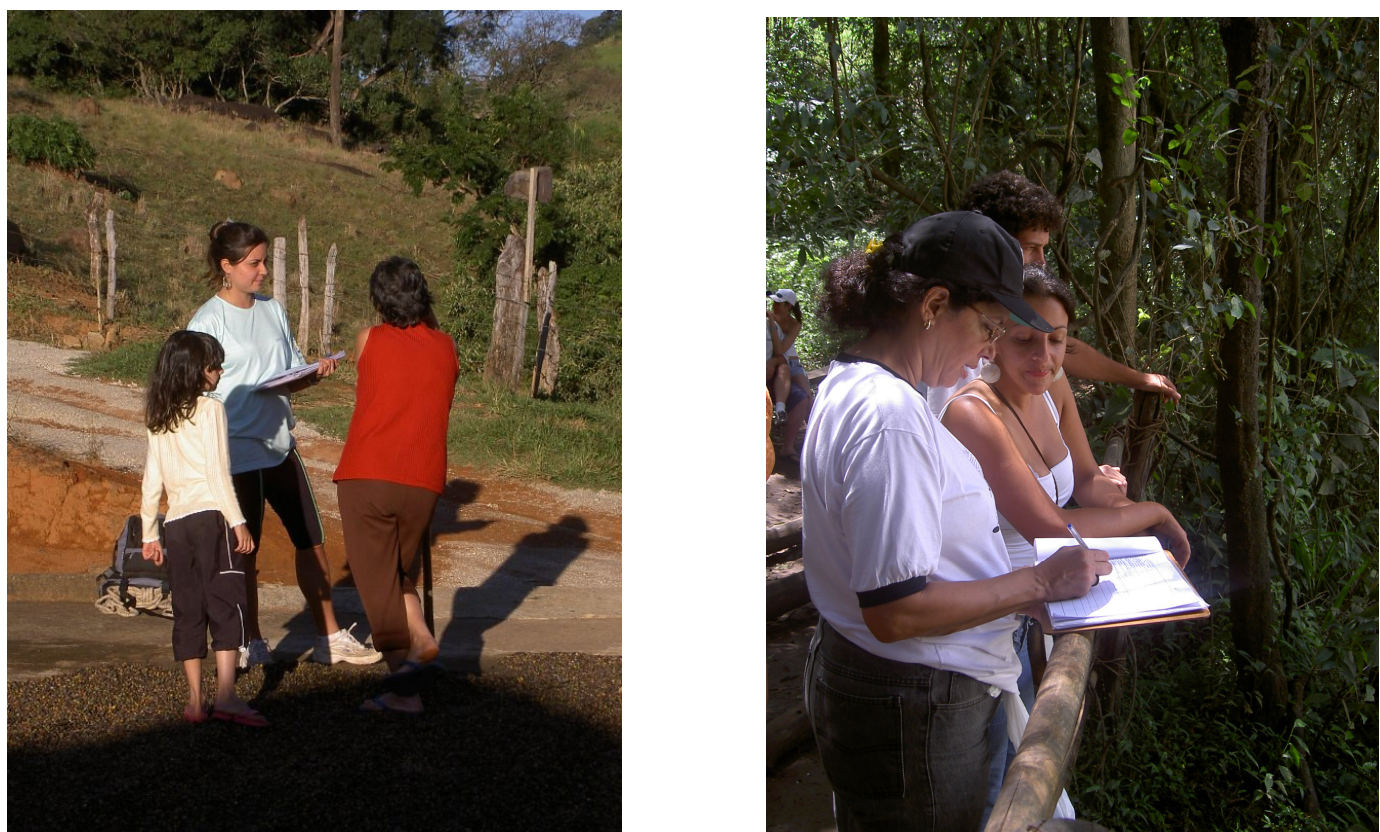

Figuras 11 e 12. Entrevistas com a população local e turistas Fonte: Hanai(2006)

Hanai, Espíndola e Brigante (2007) destacam, porém, que o Núcleo de Turismo do Projeto Mogi-Guaçu jamais buscou impor a idéia de que o desenvolvimento generalizado do turismo é a alternativa única, imediata e ideal para solução dos vários problemas da região. E muito menos foi intenção do projeto elaborar e implementar um Plano de Turismo idealizado para as localidades da região, diferenciando-se de muitos casos mal-sucedidos que colocam as ações turísticas planificadas de forma impositiva, e que muitas vezes é concebido distante (física e conceitualmente) da realidade local.

As pesquisas e ações do núcleo de turismo do Projeto Mogi-Guaçu em Bueno Brandão, portanto, tiveram como foco a caracterização e o levantamento de informações locais, com ênfase nos atrativos e empreendimentos locais e perfil dos visitantes e da população local. Essas informações propiciaram a elaboração de um procedimento de análise e avaliação do processo de desenvolvimento turístico na 
região (pesquisa de doutorado de Frederico Yuri Hannai), além dos elementos e subsídios levantados pelo presente trabalho, com o intuito de oferecer caminhos e etapas iniciais para futuras inserções da avaliação ambiental em ações estratégicas de planejamento turístico.

Em uma das reuniões do núcleo de turismo do Projeto Mogi-Guaçu - com diversos representantes do poder público municipal, empresários de turismo, produtores rurais, associações, ONGs, dentre outros grupos de interesse percebeu-se um interesse coletivo em elaborar um plano de desenvolvimento turístico para a cidade.

Da mesma forma que não era intenção do Projeto Mogi-Guaçu intervir diretamente na elaboração do plano de desenvolvimento turístico da cidade, também não foi intento deste trabalho realizar uma avaliação ambiental estratégica, mas avaliar as condições locais para uma possível inserção da AAE e de que maneira isso poderia ser realizado frente à realidade local.

\subsection{Bueno Brandão: caracterização geral}

Localizado no sul do Estado de Minas Gerais (ver figura 13), distante 458 km da capital Belo Horizonte e próximo à fronteira com o Estado de São Paulo, o Município de Bueno Brandão faz parte de uma região estratégica e privilegiada pela beleza de seus vales, paisagem montanhosa exuberante, clima ameno e diversas nascentes que, por conta do relevo, formam uma grande quantidade de quedas d'água (ver figuras 14 a 19). 


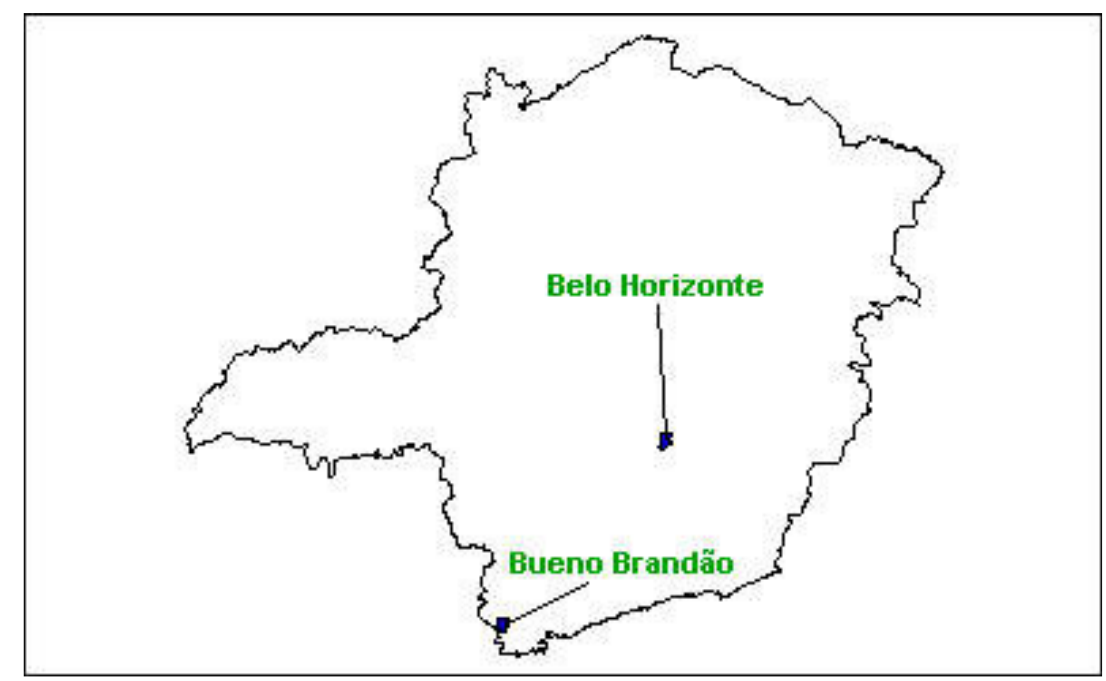

Figura 13. Mapa do Estado de Minas Gerais

Fonte: Instituto de Desenvolvimento Integrado de Minas Gerais (INDI) (2006)

Com $355 \mathrm{Km}^{2}$ de extensão e 70\% de seu território montanhoso, Bueno Brandão está localizada a $1.200 \mathrm{~m}$ de altitude, o que condiciona seu clima a temperaturas amenas, com médias anuais de $24,3^{\circ} \mathrm{C}$ (INDI, 2006).

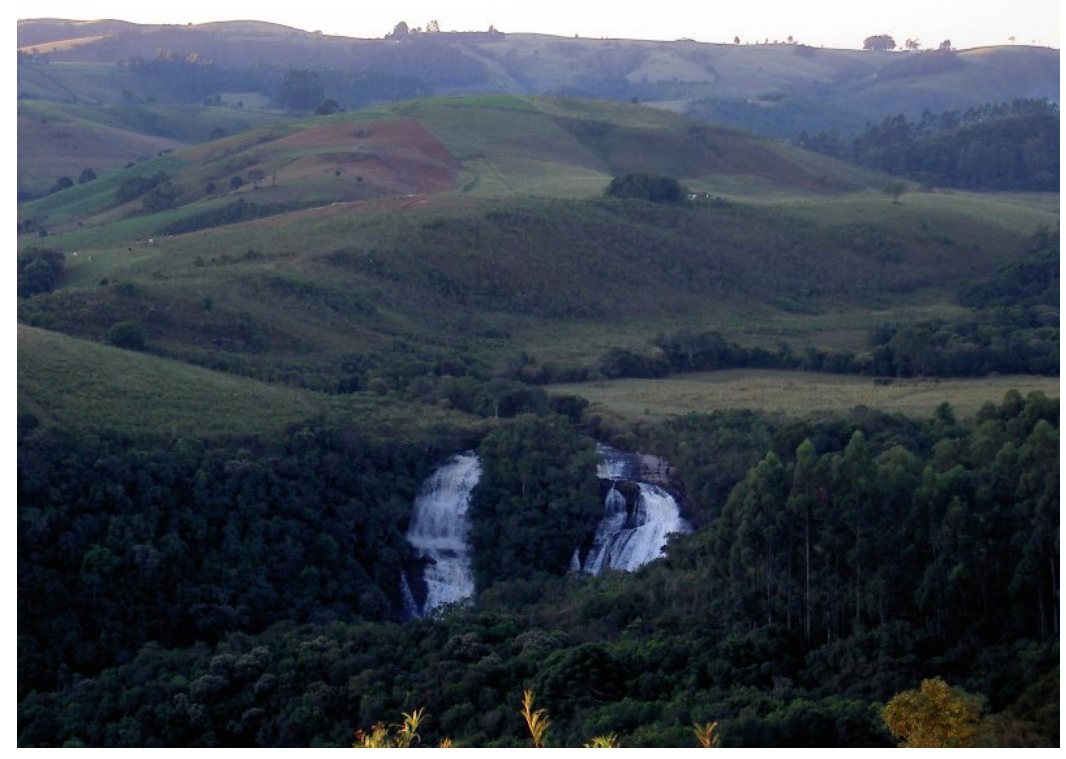

Figura 14: Paisagem montanhosa do município de Bueno Brandão e cachoeira dos Luis. Fonte: Hanai (2006) 
De acordo com o último censo do Instituto Brasileiro de Geografia e Estatística (IBGE), Bueno Brandão possui uma população estimada de 11.039 habitantes (IBGE, 2006). Pouco mais de 50\% desses habitantes moram na zona rural e boa parte, cerca de $53 \%$ da população ocupada, está ligada ao setores agropecuário, extrativista ou de pesca; enquanto quase 19\% está empregada no setor de serviços (INDI, 2006).

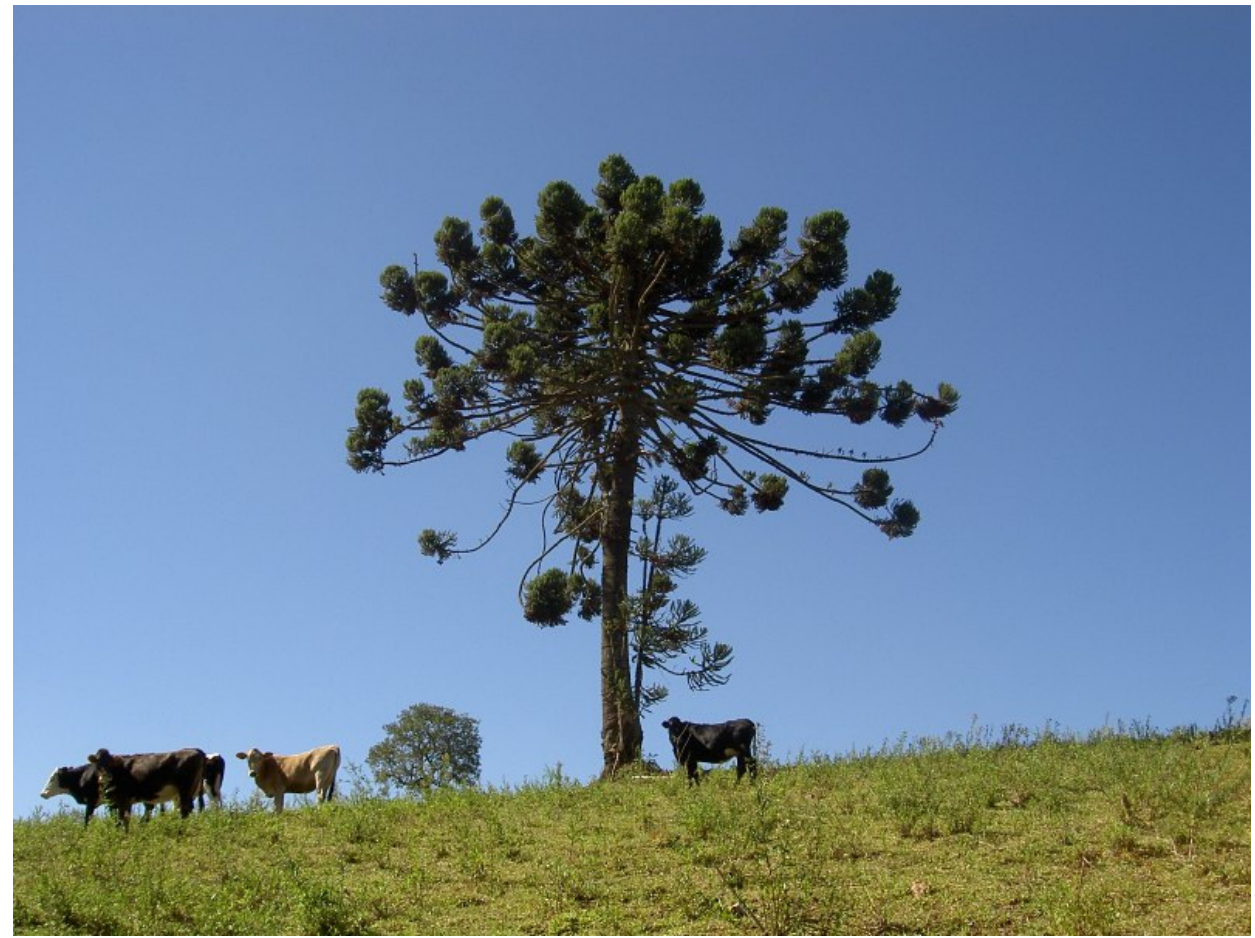

Figura 15. Área de pasto na zona rural de Bueno Brandão Fonte: Hanai (2006)

O Município de Bueno Brandão, de acordo com levantamento divulgado pelo Programa das Nações Unidas para o Desenvolvimento (PNUD), possui índice de desenvolvimento humano (IDH) no valor de 0,769. Esse índice, que afere as condições de renda, educação e longevidade da população, pode ser considerado 
positivo se comparado ao IDH médio das cidades com menos de 50 mil moradores no Brasil, que é de 0,693 (PNUD, 2007).

No setor agropecuário, o cultivo de batata inglesa ganha destaque. Em relação à produção em toneladas, a batata é o primeiro item dentre os produtos agrícolas locais. Segundo dados mais recentes do INDI (2006), a produção no ano de 2003 foi de 17.220 toneladas. Em seguida aparece o cultivo de milho, com produção de 1.230 toneladas; e a cana de açúcar, com 1.080 toneladas.

Segundo dados mais recentes, a agricultura ainda é o setor que mais contribui com o PIB municipal. A tabela a seguir, porém, mostra uma tendência de crescimento do setor de serviços, aqui incluso o comércio e o turismo, enquanto a agricultura vem dando mostras de estagnação.

Tabela 2 - Produto Interno Bruto a preços correntes (Mil Reais)

\begin{tabular}{llll}
\hline Ano & Agropecuário & Indústria & Serviço \\
\hline 1999 & 12.359 & 3.357 & 17.828 \\
2000 & 13.867 & 3.846 & 18.346 \\
2001 & 10.615 & 3.966 & 19.691 \\
2002 & 11.108 & 4.312 & 21.449 \\
2003 & 10.421 & 4.201 & 23.509 \\
\hline
\end{tabular}

Fonte: INDI (2006) e IBGE (2006)

Percebe-se, portanto, a influência significativa que o setor de serviços desempenha na economia local. Mesmo com um percentual bem menor de mão de obra empregada, o setor atingiu, no ano de 2003, mais que o dobro das receitas 
provenientes do setor agropecuário. O turismo, atividade que tem como uma de suas bases a prestação de serviços e influencia diversos setores da economia, parece contribuir para esses resultados no Município de Bueno Brandão.

As características geográficas, paisagísticas e climáticas, somadas à receptividade da população local, fazem de Bueno Brandão um local cada vez mais procurado por turistas. O crescimento dessa atividade, portanto, está sendo impulsionado, principalmente, pelo forte apelo das características naturais da região e se intensificou como atividade econômica de relevância nos últimos cinco anos.

Dentre os atrativos naturais que despertam o interesse dos visitantes destacam-se os picos, com altitudes que chegam a cerca de $1.500 \mathrm{~m}$. São locais procurados para a prática de caminhada, esportes radicais ou contemplação, pois propiciam belas paisagens de vales e montanhas.
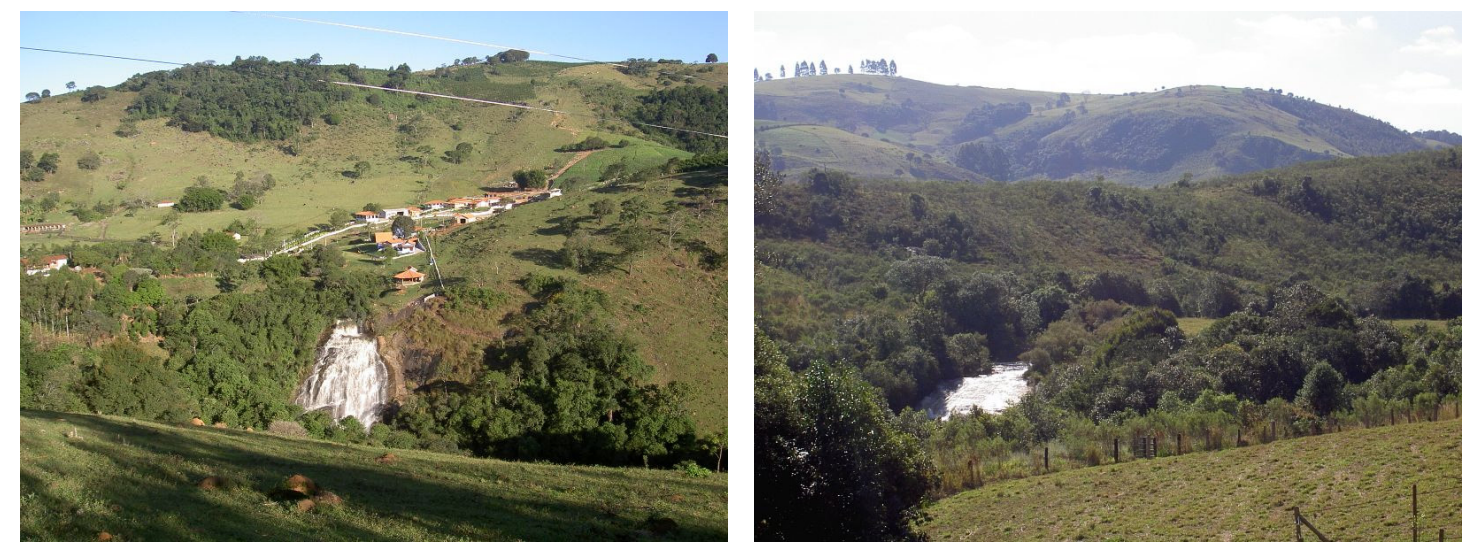

Figuras 16 e 17. Pousada junto à Cachoeira dos Félix e paisagem com fragmentos de vegetação nativa Fonte: Hanai (2006)

O maior destaque da região, porém, são as cachoeiras, o que fez com que a cidade passasse a ser denominada "cidade das cachoeiras". Elas podem variar 
desde grandes quedas d'água de até $100 \mathrm{~m}$ de altitude a pequenas corredeiras com grutas e lagos, usadas para banho, contemplação e prática de esportes. Nem todas, porém, estão abertas para visitação turística, seja pela dificuldade de acesso, falta de infra-estrutura, ou até mesmo limitação por parte dos proprietários das terras.
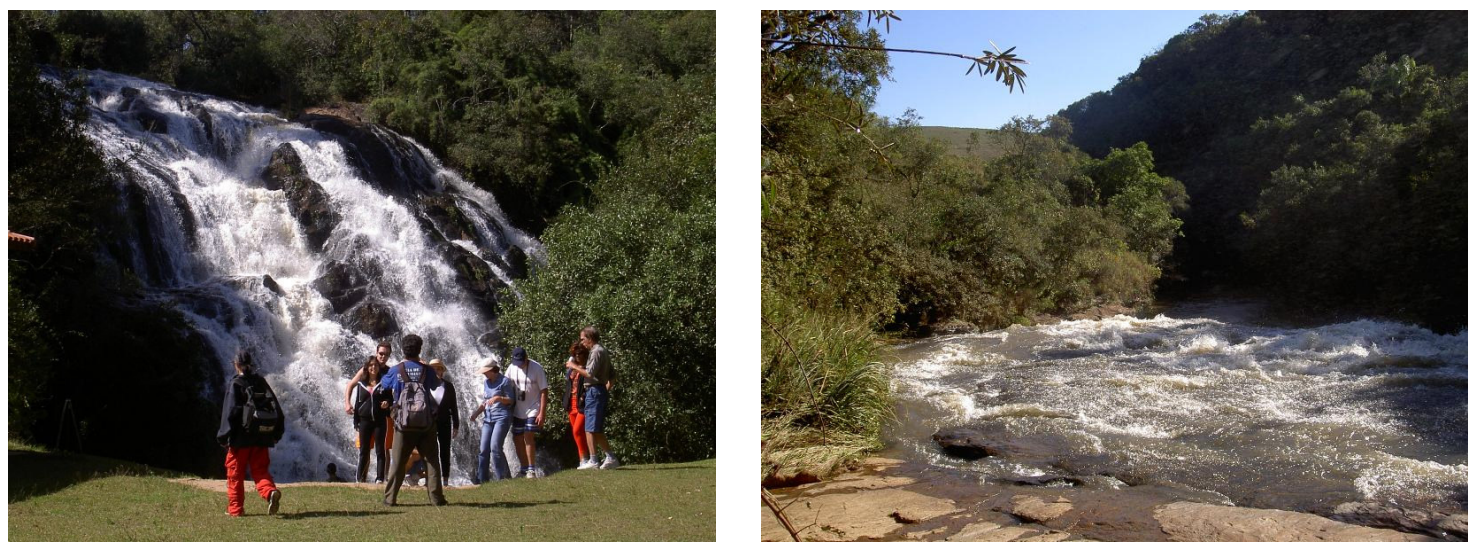

Figuras 18 e 19. Turistas e cachoeiras na área rural de Bueno Brandão Fonte: Hanai (2006)

Apesar da contribuição da atividade para o desempenho de setor de serviços, a infra-estrutura turística ainda é, em grande parte, informal. Identificando a oportunidade de diversificar as opções de receitas, muitos proprietários rurais adaptam suas propriedades para receber visitantes, por meio do aluguel de quartos, chalés ou espaços para acampamento. Essas propriedades, apesar de informais, já oferecem uma grande quantidade de serviços relacionados à vida no campo como hospedagem, alimentação típica e produção e venda de artesanato, bebidas tradicionais, doces, queijos, geléias etc.

Já existem também agências de turismo receptivo, com guias treinados, que oferecem atividades como passeios em trilhas, caminhadas de contemplação e 
esportes em áreas naturais. Além disso, alguns moradores locais alugam suas casas para temporadas, feriados ou finais de semana.

Por outro lado, Hanai, Espíndola e Brigante (2007) destacaram que o grande fluxo de visitantes, principalmente nos feriados e finais de semana, lota os estabelecimentos de hospedagem (pousadas e hotéis e campings) (ver figuras 20 e 21) e tem ocasionado diversos impactos negativos nos locais naturais de visitação, principalmente em cachoeiras e rios, comprometendo a conservação das áreas naturais e a qualidade da experiência de visitação.
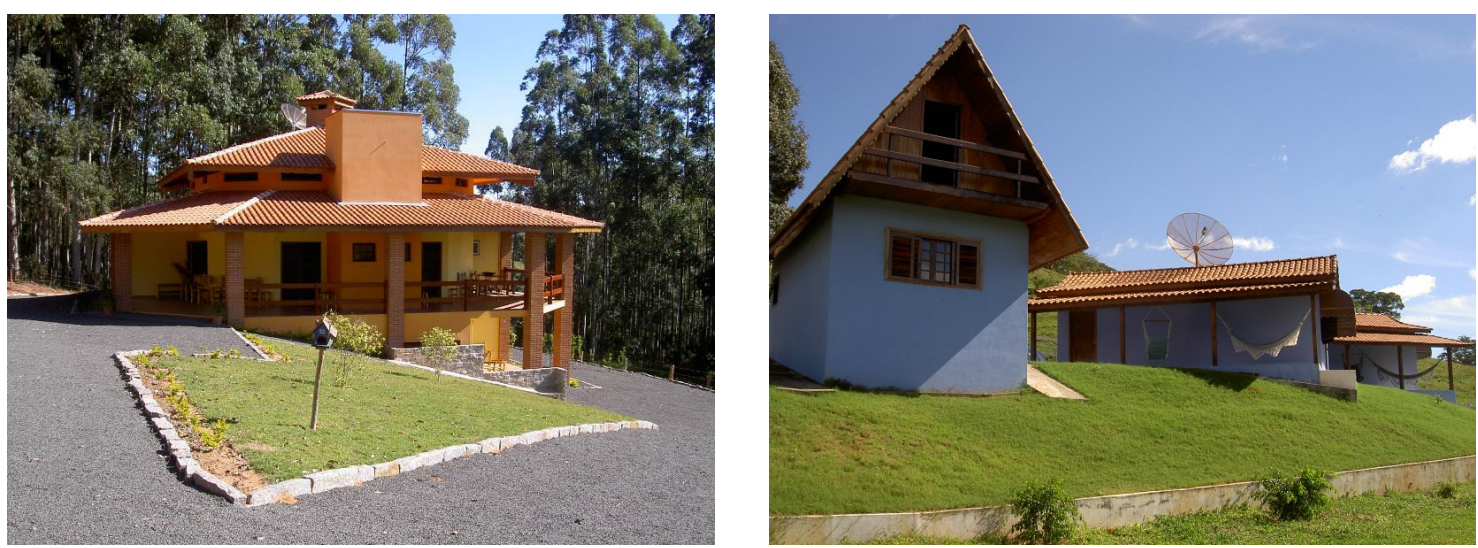

Figuras 20 e 21. Chalés de pousadas de Bueno Brandão Fonte: Hanai (2006)

Assim, a emergência do turismo, apesar de já apresentar resultados positivos em relação às oportunidades econômicas que estão surgindo no município de Bueno Brandão, impõe também uma série de questionamentos sobre a forma como ocorre o desenvolvimento da atividade, sua relação com os recursos naturais e culturais da região, os impactos positivos e negativos decorrentes e os possíveis conflitos com outras atividades econômicas, especialmente a agropecuária. O fato de o turismo apresentar um crescimento significativo nos últimos anos, portanto, faz 
com que essas questões sejam alvo de discussões por parte do poder público, empresários e alguns representantes da sociedade civil local.

\subsection{Plano de desenvolvimento do turismo}

As primeiras iniciativas de planejamento turístico eram movidas basicamente por objetivos e metas econômicas. Atualmente, diversas outras preocupações são discutidas e incluídas em processos de planejamento do turismo como a necessidade de se manter os níveis de qualidade ambiental, o respeito às populações locais, a inclusão social, a qualidade do produto turístico etc. O planejamento assumiu então um papel de maior relevância no desenvolvimento turístico à medida que os governos passaram a reconhecer não apenas que o setor gera um largo espectro de impactos, mas também que pode ter um importante papel no crescimento e revitalização social e cultural (OMT, 2003).

O planejamento por parte do poder público pode ocorrer nas diversas esferas da administração pública e as questões a serem consideradas em cada um desses níveis variam consideravelmente na medida em que as responsabilidades institucionais e políticas são devidamente delimitadas.

Segundo a OMT (2003) o planejamento do turismo local, ou seja, no âmbito municipal, em geral está associado às seguintes questões:

- políticas de zoneamento e planejamento de uso do solo;

- criação e aplicação de regulamentações ambientais;

- facilitação do envolvimento de grupos de interesse;

- planejamento de infra-estrutura;

- fornecimento de vias de acesso às instalações privadas; 
- fornecimento de serviços para visitantes e moradores;

- educação, treinamento e outros serviços de recursos humanos;

- financiamento para o desenvolvimento turístico;

- marketing e promoção e;

- questões relativas à tributação.

Com o intuito de sistematizar essas atribuições, as autoridades e planejadores freqüentemente se utilizam do plano de desenvolvimento turístico. Esse plano deve identificar e reconhecer os principais problemas relacionados ao desenvolvimento do turismo no local e estabelecer estratégias para superá-los, incentivando formas de desenvolvimento responsáveis e harmoniosas.

\subsection{Subsídios para avaliação ambiental estratégica}

\subsubsection{Estrutura administrativa e institucional de gestão do turismo em Bueno Brandão}

Atualmente, a gestão do turismo na estrutura administrativa pública é feita pelo Departamento de Turismo, Cultura, Desporto e Lazer. A figura 22, mostrada a seguir, situa esse departamento juntamente com os demais órgãos da administração pública. 


\section{Prefeitura Municipal de Bueno Brandão}

Prefeito

\section{Vice-Prefeito}

Chefia de Gabinete Assessoria de Comunicação Social

\section{Departamentos}

Departamento de Ação Comunitária e Saúde Departamento de Administração e Planejamento Departamento de Turismo, Cultura, Desporto e Lazer Departamento de Finanças, Contabilidade e Tesouraria Departamento de Obras, Viação e Serviços Públicos Departamento de Educação Departamento de Desenvolvimento Rural e Meio Ambiente Departamento de Materiais

Figura 22. Prefeitura Municipal de Bueno Brandão

Fonte: Prefeitura Municipal de Bueno Brandão (2007)

O Departamento em foco era conduzido, no momento da realização da pesquisa, por três funcionários e três monitores.

Como órgão responsável pela formulação e implementação das políticas públicas relacionadas ao turismo, esse órgão deve se posicionar se não de forma direta na avaliação ambiental estratégica, pelo menos de maneira muito próxima. É necessário ressaltar que, mesmo em casos em que a administração pública se utilize de consultores ou organizações externos, o departamento responsável pela direção do setor não pode abrir mão de ser um dos principais atores nesse processo.

A utilização de uma consultoria externa é positiva em experiências iniciais devido à limitada capacidade técnica e profissional de planejadores e funcionários públicos locais que desconhecem o instrumento, especialmente na realidade brasileira. Além disso, uma equipe de profissionais externos pode facilitar a 
mediação entre grupos de interesses diversos e trazer mais imparcialidade para a avaliação.

Por outro lado, é o quadro técnico e funcional da prefeitura que conhece a realidade do turismo na cidade, assim como as limitações financeiras e institucionais que o poder público enfrenta. A proximidade entre consultores externos e os membros do governo tomadores de decisão é essencial para que as recomendações propostas na AAE estejam próximas da realidade e da capacidade institucional e política dos órgãos governamentais responsáveis pela implementação das ações. Do contrário, corre-se o risco de a AAE se transformar, como já destacado, num estudo de gaveta.

A participação de planejadores e tomadores de decisão também pode ser crucial para garantir que as sugestões apontadas pelos relatórios da AAE serão realmente incorporadas às ações e políticas públicas e, assim, postas em prática. Como já identificado na experiência internacional, se os responsáveis pela tomada de decisão e a instituição propositora da política não participarem de forma ativa na avaliação fica mais difícil garantir que os resultados e as recomendações da $A A E$ sejam realmente levados em consideração.

Diversas possibilidades, no que se refere à condução da $A A E$, são possíveis. Algumas são expostas a seguir e são passíveis de combinações diversas entre elas. Vale destacar o que Therivel (1998) já havia identificado em experiências no Reino Unido, que, na prática, a avaliação era feita por um grupo pequeno de avaliadores e, em grande parte dos casos, por um avaliador apenas. As possibilidades em Bueno Brandão seriam: 
- Avaliação coordenada pela própria equipe responsável pela elaboração da política (possibilidade de participação de outros órgãos governamentais).

O próprio quadro técnico do departamento de turismo seria responsável pela avaliação, eventualmente participariam representantes de outros departamentos da administração pública ou da chefia de gabinete do prefeito. Nesse caso, duas questões são questionáveis. A primeira delas está relacionada à capacidade técnica dos funcionários do departamento, que desconhecem o instrumento, e a segunda diz respeito à capacidade de imparcialidade dos planejadores.

- $\quad$ Avaliação coordenada por consultoria externa em conjunto com a equipe responsável pela elaboração da política (possibilidade de participação de outros órgãos governamentais).

A avaliação conduzida por consultores externos é benéfica, pois pode funcionar como um mediador imparcial de conflitos e facilitar a consulta pública. Além disso, é essencial quando não há familiaridade com o instrumento por parte dos membros da administração pública, caso de Bueno Brandão. Por outro lado, pode acarretar um ônus financeiro que muitas prefeituras de pequeno porte não estão em condições de arcar.

- $\quad$ Avaliação coordenada por um especialista interno em avaliação ambiental em conjunto com a equipe responsável pela elaboração da política (possibilidade de participação de outros órgãos governamentais).

Em países com mais experiência no campo da avaliação estratégica já é comum a existência de um funcionário, em departamentos e secretárias setoriais, especialista em avaliação ambiental. Ele seria o responsável por realizar a 
avaliação, ou seja, articular as informações, fornecê-las aos planejadores, elaborar relatórios e coordenar as discussões de articulação com outros órgãos da administração pública e com a sociedade. Ainda é uma realidade muito distante no Brasil, especialmente no âmbito municipal, e deve demandar tempo para que funcionários e planejadores públicos atinjam esse grau de especialização.

\subsection{2 Âmbito de aplicação}

Já é possível encontrar experiências de elaboração de políticas municipais de turismo, especialmente, em importantes centros receptores como Brotas, SP e Bonito, MS. Nesses casos, freqüentemente, as políticas são estabelecidas na forma de lei municipal, de modo a estabelecer instrumentos regulatórios e de gestão para o desenvolvimento turístico local.

A adoção da AAE para ações estratégicas municipais em planos de turismo pode ser mais viável por duas razões. A experiência de aplicação da AAE em políticas ainda é pouco comum, especialmente pelo fato de se tratar de questões mais conceituais, com direcionamentos muito abrangentes. Ainda existem, portanto, muitos desafios nesse campo. A análise da experiência mundial mostrou, inclusive, que, mesmo nos casos em que a AAE é aplicada em políticas, essas se aproximam muito do conceito de planos, com objetivos específicos e voltados para a ação. Além disso, o principal instrumento para planejamento setorial do turismo no âmbito municipal ainda é o plano de desenvolvimento turístico.

É importante destacar que esses planos não podem estar dissociados de outras estratégias regionais, estaduais e nacionais. A discussão sobre a aplicação da AAE no âmbito municipal não pode desconsiderar a adoção desse instrumento 
em outros níveis governamentais, pois são essas questões que garantem avaliações em cascata, com cada nível de planejamento influenciando e estabelecendo melhores contextos para os níveis seguintes.

Essa situação ganha importância no contexto atual, em que o Governo Federal, por meio do Ministério do Turismo, estimula ações de planejamento e ações de marketing regionais. Esse fato reafirma a necessidade de que essas estratégias também sejam sujeitas à AAE. Do contrário, as experiências municipais podem contribuir pouco para garantir formas menos impactantes de turismo.

Apesar de ser importante para o direcionamento da atividade turística em Bueno Brandão, não existe atualmente uma política ou um plano formal que indique as diretrizes de orientação do turismo local. Essa situação está relacionada ao fato de o turismo ser um fenômeno recente no Município e, dessa forma, apenas recentemente passou a ser alvo de maior atenção do poder público local. Além disso, o órgão responsável pela gestão do setor ainda acumula muitas funções, com limitada capacidade financeira, pessoal e técnica. A atuação municipal em relação à gestão do turismo tem sido muito mais reativa, em função do surgimento de demandas. Por essas razões, acredita-se que a elaboração, implementação e monitoramento de um plano de turismo deve se configurar como um grande desafio para o poder público local.

Por outro lado, a municipalidade dispõe de outros instrumentos e políticas correlatas, alguns já adotados em Bueno Brandão, e que podem incorporar questões relativas ao desenvolvimento turístico local, além de também serem passíveis de avaliação ambiental estratégica. A seguir estão relacionadas as possibilidades de gestão do turismo e os diversos instrumentos da administração pública municipal: 


\section{Política Municipal de Turismo de Bueno Brandão:}

Deve estabelecer, na forma de lei municipal, os instrumentos de regulação e gestão da atividade. São exemplos desses instrumentos:

- o Fundo Municipal de Turismo;

- o Conselho Municipal de Turismo;

- o Licenciamento Turístico;

- o Sistema Municipal de monitoramento e controle da visitação etc.

\section{Plano de Desenvolvimento Turístico de Bueno Brandão:}

É freqüentemente utilizado na gestão municipal do turismo. O plano de turismo segue, geralmente, as mesmas etapas de um processo de planejamento tradicional, com algumas particularidades, o que facilita a inserção da AAE. As principais etapas são:

- determinação de objetivos;

- caracterização da situação atual (inventário turístico, estudo de mercado, análise da atuação e capacidade dos atores institucionais etc.);

- prognóstico e programas de ação (identificação de oportunidades e ameaças, identificação de necessidades para programas de ação como capacitação e qualificação de recursos humanos, promoção e marketing, sinalização turística, proteção e controle de áreas naturais, financiamento para o desenvolvimento turístico etc.) e;

- monitoramento dos objetivos. 


\section{Políticas Correlatas:}

O Município deve garantir que outros instrumentos e políticas de planejamento garantam a incorporação de questões referentes ao planejamento turístico. São algumas das ações que também podem ser passíveis de avaliação ambiental estratégica:

- Planejamento da infra-estrutura viária:

Estabelece ações para construção e melhoria das vias de acesso. Deve incorporar questões relacionadas ao desenvolvimento turístico pois pode estimular um fluxo turístico que os atrativos naturais não estão preparados para receber. Deve estar associado a um programa de proteção e controle da visitação nessas áreas.

- Plano Diretor e Lei de Uso e Ocupação do Solo:

O principal instrumento de gestão do uso do solo em Bueno Brandão é o Plano Diretor. Numa realidade de carência de recursos financeiros e pessoais, capaz de inviabilizar a elaboração e implementação de um plano de turismo municipal, o Plano Diretor e a Lei de Uso e Ocupação do Solo podem ser alternativas, se incorporarem questões referentes ao planejamento turístico e se sujeitos à avaliação ambiental estratégica. É necessário destacar que não é função desses instrumentos incorporar todas as questões que dizem respeito ao planejamento do turismo, mas, no momento em que estabelecem limites e critérios para uso e ocupação do solo, integram diversos setores e atividades em torno dessa questão e oferecem oportunidades de participação da sociedade, podem ser uma alternativa para 
municípios com pouca capacidade institucional e financeira na gestão do turismo.

- Códigos de Obras e Posturas:

Os Códigos de Obras estabelecem limitações cujo objetivo é disciplinar e regular edificações. Podem ser utilizados para exigir padrões construtivos mínimos para empresas turísticas. Os Códigos de Posturas são instrumentos legais que regulam a utilização de espaços públicos, o uso coletivo dessas áreas, o controle de ruídos, atividades causadoras de incômodos etc.

- Gestão de resíduos

Os municípios são responsáveis pela gestão de seus resíduos e, freqüentemente, se utilizam de um Plano de Gestão de Resíduos Sólidos como instrumento básico para conceber, implementar e administrar ações de redução, aproveitamento e tratamento dos resíduos sólidos. Apesar de algumas questões exigirem soluções que extrapolam a capacidade de ação da prefeitura em termos de investimentos, recursos humanos e financeiros, especialmente no que diz respeito à destinação final, o poder público municipal deve garantir a mobilização de segmentos sociais locais, inclusive os envolvidos com o turismo, trabalhando aspectos relacionados à redução da geração de resíduos, coleta seletiva, destinação correta etc.

\subsubsection{Integração}

A quase ausência de ações de planejamento integradas, que caracterizam a intersetorialidade, não é atributo exclusivo do Município de Bueno Brandão. Como já destacado, essa é uma falha no sistema político-institucional brasileiro e deve 
configurar como um grande desafio na inserção de questões ambientais na gestão local do turismo.

Atualmente, as ações conjuntas entre órgãos da administração pública em Bueno Brandão são fundamentalmente reativas e se resumem à solução de problemas de ordem prática, no que diz respeito às demandas administrativas diárias de cada departamento, o que dá espaço para o surgimento de processos lentos e burocráticos.

Se mesmo o planejamento tradicional, pelo menos no âmbito da atividade turística, sofre de carências administrativas, técnicas e pessoais, as ações integradas dos demais órgãos da administração local deve ser um passo ainda mais distante dessa realidade setorializada e burocrática. Esse fato também dificulta a integração metodológica. Já que não existe um padrão ou uma cultura de planejamento, a administração pública deverá encontrar meios próprios de inserção da AAE, de acordo com suas possibilidades e capacidades.

O planejamento do turismo, por si só, já exige a consideração de outras políticas, planos e programas relacionados, por se tratar de uma atividade tão multisetorial. A AAE deve estimular a consolidação desse processo, fazendo das questões ambientais um ponto de convergência entre os diversos atores da administração pública.

Além disso, deve-se buscar contextualizar as ações locais com a realidade nacional, estadual e regional, identificando direções, objetivos e metas de outros PPPs; as suas implicações para o Plano de Desenvolvimento Turístico de Bueno Brandão e as respostas do plano a esses requisitos, exigências e objetivos. Por outro lado, sem a adoção da AAE em todos os níveis governamentais corre-se o risco de se reafirmar objetivos equivocados, que não foram sujeitos à $A A E$. 


\subsubsection{Participação e transparência}

A equipe do Projeto Mogi-Guaçu levantou e analisou algumas informações referentes à opinião da população local sobre mobilização e expectativas geradas pelo desenvolvimento turístico. Esses resultados mostram um quadro com importantes informações a respeito da disposição dessas pessoas em participar das decisões locais no que diz respeito ao desenvolvimento turístico.

Apesar de o turismo ser uma das principais atividades econômicas e empregar considerável quantidade de mão-de-obra, a população de Bueno Brandão considera saber pouco ( $82 \%$ dos entrevistados) ou nada ( $18 \%$ dos entrevistados) sobre turismo, conforme ilustra a figura 23.

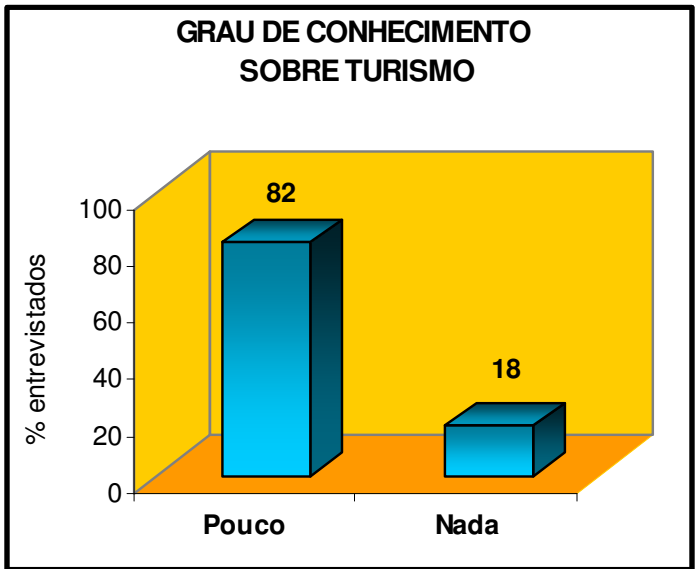

Figura 23. Grau de conhecimento sobre turismo dos moradores de Bueno Brandão Fonte: Hanai, Espíndola e Brigante (2007)

Observou-se também que $43 \%$ dos moradores entrevistados não possuem interesse em se envolver nas decisões sobre o futuro do desenvolvimento turístico (Figura 24). Esse dado pode apontar, conforme afirmaram Hanai, Espíndola e 
Brigante (2007), para o pouco interesse da população local em participar de decisões sobre o turismo, o que reflete a necessidade de ações que promovam mobilização da sociedade e que introduzam princípios de cooperativismo. Mas também pode ser resultado de uma parcela da população que não se sente parte do turismo, ou seja, pessoas que não estão envolvidas profissionalmente com essa atividade ou não se sentem afetadas por ela no seu dia-a-dia.

É correto afirmar que o turismo local ainda vem ocorrendo de forma mais espontânea do que planejada, com pouca profissionalização e desconhecimento da população em geral, porém, o fato de que $57 \%$ da população têm interesse em participar das decisões sobre o desenvolvimento turístico local é considerável e significativa.

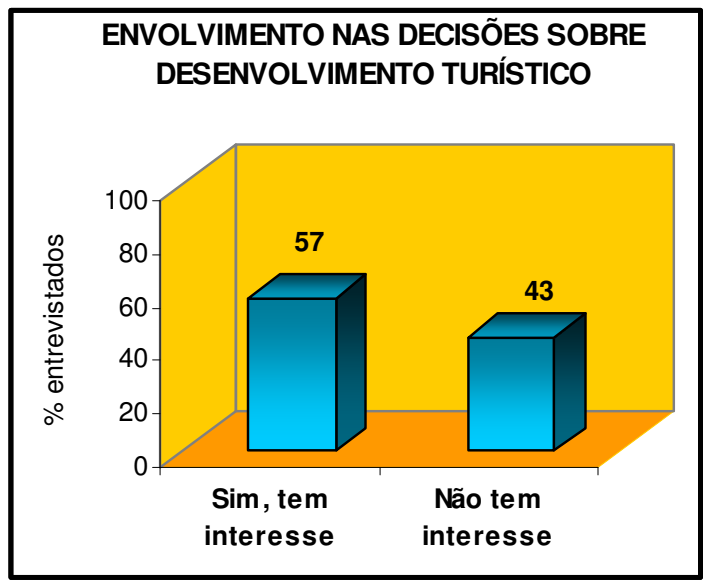

Figura 24. Disposição dos moradores de Bueno Brandão em participar das decisões do desenvolvimento turístico no município Fonte: Hanai, Espíndola e Brigante (2007) 
O que é necessário destacar nesses casos é a questão da representatividade dessa população nos canais de participação e sua capacidade de influenciar e intervir de forma direta na tomada de decisão.

Já existem, em Bueno Brandão, alguns canais, instituídos por lei, que fornecem oportunidades de participação de representantes da sociedade em discussões de questões de interesse público e que podem representar oportunidades para futuras experiências de avaliação ambiental estratégica em turismo. Nesse caso destaca-se aqui o Conselho Municipal de Turismo (CONTUR) e o Conselho Municipal de Desenvolvimento Ambiental (COMDEMA).

O CONTUR foi instituído em Bueno Brandão em 1997, por meio da Lei Municipal $\mathrm{N}^{\circ} 022 / 97$, que caracteriza o Conselho como órgão de caráter consultivo e deliberativo, para assessoramento da municipalidade em questões referentes ao desenvolvimento turístico do município.

Dentre as principais competências do CONTUR está a de debater sobre os temas de interesse turístico para a cidade, manter atualizado o cadastro de informações turísticas, formular as diretrizes básicas para a política municipal de turismo, desenvolver programas e projetos de interesse turístico, promover e divulgar atividades ligadas ao turismo, propor e divulgar critérios para a programação e para as execuções financeiras e orçamentárias do Fundo Municipal de Turismo, dentre outras.

Apesar de existir em forma de lei, o CONTUR nunca esteve realmente ativo no cumprimento de suas funções e vários são os problemas creditados a essa inoperância. O principal deles diz respeito à composição dos representantes. De acordo com a lei, esse órgão deve ser constituído por dezoito membros efetivos, com 6 representantes do poder público local (Câmara Municipal e Prefeitura), 6 
representantes da iniciativa privada (empresários dos mais diversos ramos do turismo como agências, hotéis, empresas de transporte, entretenimento e restaurantes), 3 representantes de associações e sindicatos, 2 representantes da imprensa e um representante do COMDEMA. Há várias divergências quanto ao número de componentes e argumenta-se que alguns membros são dispensáveis por não representarem grupos de interesse.

Além disso, não existe uma posição política local, por parte do executivo, no sentido de valorizar e fortalecer os mecanismos de representação e participação da sociedade em tomadas de decisão. Essa falta de compromisso acaba por esvaziar esses instrumentos que só existem na forma de lei. Muitas vezes impera o argumento de que as informações estratégicas são "segredo de Estado", o que dificulta a democratização do processo de discussão pública de interesses coletivos.

Outro órgão colegiado, também criado por lei em 1997 (Lei Municipal $N^{\circ 1.280}$, de 03.06.1997), e que passa por uma situação semelhante, é o Conselho Municipal de Desenvolvimento Ambiental - COMDEMA, órgão de caráter consultivo de assessoramento ao poder executivo municipal e deliberativo em relação a algumas questões como emissão de alvarás de localização e funcionamento de atividades potencialmente poluidoras, bem como sobre solicitações de certidões para licenciamento. O conselho é composto, de forma paritária, por representantes do poder público e da sociedade civil.

O COMDEMA de Bueno Brandão é um exemplo emblemático de falta de representatividade da sociedade no que deveria ser um órgão consultivo e participativo. A sua atuação se resume a um presidente, indicado pelo executivo, que atua de forma centralizada e alheia aos dispositivos previstos por lei de representação e participação de outros grupos e representantes da sociedade. 
Essa falta de representatividade está relacionada com o risco que os canais institucionais de participação correm de funcionarem como instrumentos legitimadores de certa classe política local ou de grupos influentes e dominantes economicamente, deixando à revelia os anseios e as demandas de uma parcela menos favorecida da sociedade local. Por isso, acredita-se que o fim da cultura de centralização que existe em Bueno Brandão e em muitos municípios brasileiros só deve ocorrer com o fortalecimento de organizações sociais e com o compromisso político em fortalecer os mecanismos de participação.

\subsubsection{Referências, informações e monitoramento}

Um dos princípios da AAE é que políticas, planos e programas sejam avaliados de acordo com objetivos, parâmetros ou políticas de sustentabilidade, ou seja, que exista uma base de referências que possam balizar a construção dessas políticas e sejam incorporadas às questões estratégicas. Essas referências estão diretamente relacionadas a um outro princípio que é a coleta, produção e sistematização contínua de informações ambientais.

Uma futura experiência de AAE deve demandar um esforço coletivo de pesquisa e sistematização de informações. Isso porque em Bueno Brandão, assim como em muitos municípios do Brasil, não existe uma base de dados ambientais, ou seja, não há uma cultura de armazenamento e utilização de informações ambientais com o intuito de dar suporte ao planejamento e à tomada de decisão.

Além disso, a análise da experiência internacional mostrou que os estudos trazem um apanhado extenso de informações, muitas vezes desnecessárias e descontextualizadas das questões que realmente interessam na avaliação em foco. 
O turismo em Bueno Brandão está baseado quase que integralmente no contato e uso direto e indireto da água e na vivência e apreciação das paisagens e do modo de vida da zona rural. Deve-se buscar, portanto, manter o foco nas questões que realmente interessam nesse segmento, seja para fins de elaboração e avaliação de cenários como para monitoramento, tais como:

- recursos hídricos (aspectos quantitativos e qualitativos);

- uso e ocupação do solo (remanescentes de vegetação nativa, áreas de preservação permanente, zonas de interesse patrimonial e histórico etc.);

- resíduos sólidos (projeções de produção e capacidade de coleta e destinação final etc.);

- danos à biodiversidade (perspectivas de danos à flora e à fauna com as visitas às áreas naturais);

- saúde, bem-estar e inclusão social (identificar possíveis impactos negativos à população local assim como os benefícios auferidos com a atividade).

A utilização dessas informações para avaliação e monitoramento deve depender da capacidade política e institucional de sistematizá-las e torná-las úteis à rotina de planejamento e controle da atividade. Sabe-se das dificuldades e limitações técnicas, financeiras e pessoais para esse esforço. Por outro lado, atualmente, a administração pública dispõe de uma série de possibilidades de parcerias e trabalhos conjuntos com universidades, organizações da sociedade civil, institutos de pesquisa e até com a própria iniciativa privada.

Além disso, é preciso destacar que, freqüentemente, em experiências internacionais, o poder público tem buscado discutir esses parâmetros e indicadores referenciais com representantes da sociedade, de forma que esses já 
citados podem ser um ponto de partida para discussões e adaptações à realidade local.

Deve demandar tempo e esforço político para que a municipalidade em Bueno Brandão articule uma base de dados que permita a realização de uma avaliação ambiental estratégica, porém, a experiência mostra que nem sempre um apanhado muito extenso de informações é necessário ou útil. Além disso, pode-se pensar em pequenos passos iniciais, trabalhando com informações mais básicas e mais acessíveis. O importante é que essa base de informações não seja um retrato instantâneo da realidade, mas seja constantemente atualizada para garantir o monitoramento e a avaliação contínua do desenvolvimento turístico local.

\subsubsection{Considerações finais}

Com base nas questões aqui apresentadas, nas informações e nos resultados analisados, propõe-se um conjunto de ações e situações a serem buscadas no Município de Bueno Brandão, com o intuito de facilitar a consideração das questões ambientais no planejamento e tomada de decisão de políticas de turismo de forma participativa, democrática e transparente, consolidando caminhos para futuras experiências de avaliação ambiental estratégica. Essas questões dizem respeito aos procedimentos necessários para realização da AAE.

- $\quad$ A AAE não deve ser um procedimento burocrático de aprovação ou rejeição de propostas já elaboradas. Por isso, ela deve ser encarada como um instrumento de auxílio à tomada de decisão. 
- Deve haver comprometimento, por parte da administração pública, com o desenvolvimento turístico responsável, participativo, socialmente inclusivo e harmonioso com as condições ambientais locais.

- O Poder público deve buscar o fortalecimento, através de programas de capacitação em planejamento e em avaliação ambiental estratégica, do corpo técnico e das instituições envolvidas na gestão do turismo e do meio ambiente no Município.

- Deve-se priorizar abordagens de tomada de decisão participativa por meio do fortalecimento dos mecanismos de participação social (conselhos municipais, organizações da sociedade civil, associações etc.), como espaços para democratização da informação, expressão e debates de interesses coletivos e formulação de políticas sustentáveis.

- $\quad$ A AAE não obterá sucesso sem ações e discussões articuladas entre órgãos públicos e setores relacionados, considerando outras políticas, planos e programas, e contribuindo para a busca de objetivos comuns, com maior consideração das questões ambientais de forma interinstitucional.

- Deve-se estimular a produção contínua de informações e identificação de requisitos e referências de sustentabilidade por meio do estabelecimento de um sistema transparente de informação, que articule produção, sistematização, democratização e monitoramento de informações ambientais, de forma a orientar o planejamento e a tomada de decisão, bem como possibilitando o envolvimento da sociedade civil. 


\section{CONCLUSÃO}

A velocidade com que os problemas ambientais ocorrem atualmente e as perspectivas de que devem se intensificar nos próximos anos trazem à tona a urgência da necessidade de se dar mais peso político às questões ambientais. Para tanto, é cada vez mais freqüente a utilização da $A A E$ como forma de garantir a inserção do meio ambiente na pauta de discussões estratégicas de uma maneira sistemática, transversal e contínua.

Verificou-se, com o presente estudo, experiência e prática internacional significante no campo da $\mathrm{AAE}$, além de considerável quantidade de estudos e pesquisas na área. A maioria das experiências e estudos, contudo, ainda está em curso e só o tempo deverá mostrar se a AAE está realmente influenciando a tomada de decisão e fornecendo oportunidades para a construção de políticas, planos e programas mais responsáveis em relação às suas conseqüências ambientais.

Já existe também certo consenso entre pesquisadores, planejadores e especialistas no que se refere a alguns princípios e melhores práticas de $A A E$, porém, o desafio de adaptá-los a realidades políticas e institucionais tão diversas ainda persiste.

Deve demandar tempo, portanto, para que a sociedade e os governos incorporem metodologias e práticas próprias de aplicação da AAE. Afinal, é na prática que os planejadores estão aprendendo, aprimorando metodologias, técnicas e diferentes abordagens. Espera-se que a diversidade de abordagens e metodologias reflita o conjunto heterogêneo de tipos e contextos de planejamento e tomada de decisão. 
É por isso que, em países como o Brasil, onde não existe experiência expressiva no campo da $\mathrm{AAE}$, é indispensável o exercício de reflexão e avaliação sobre possíveis formas de inserção desse instrumento em realidades específicas, seja mediante análise do processo de planejamento e tomada de decisão seja por meio das lições aprendidas na experiência internacional.

Verificou-se também que, no turismo, atividade que vive um período de crescimento contínuo e significativo, a necessidade de abordagens estratégicas na gestão dos impactos negativos da atividade é um dos preceitos e lacunas de maior urgência na atualidade.

Isso porque, ao analisar os instrumentos de gestão ambiental mais comumente usados no turismo, fica evidente o fato de que o gerenciamento de impactos acontece em momentos tardios, ou seja, o estímulo ao turismo precede o planejamento, e o Poder público, geralmente, concentra esforços em minimizar os impactos que o aumento do fluxo turístico causa em áreas naturais, desconsiderando outras conseqüências inevitáveis que essa atividade pode trazer para uma região, como a pressão sobre o arranjo territorial, a pressão sobre os recursos naturais e as reservas de água, o aumento da produção de resíduos e efluentes etc.

Várias experiências de avaliações de políticas, planos e programas de turismo foram identificadas, em diversos países, com abordagens e metodologias também diversificadas. Esses estudos, no entanto, ainda são pontuais e apresentam uma série de imprecisões em termos de metodologia, formas de participação e abordagens. A análise realizada pelo presente trabalho, porém, se restringiu aos documentos e relatórios disponíveis, que descrevem tais experiências. 
É indispensável também que as análises de futuras pesquisas versem sobre os resultados que essas experiências têm ocasionado nas atividades e realidades avaliadas, com o intuito de identificar de que forma essas AAEs estão realmente influenciando a tomada de decisão, contribuindo para o alcance de ações estratégicas mais sensíveis à questão ambiental e resultando em melhor qualidade ambiental e de vida.

Isso porque, analisando a evolução da pesquisa e da experiência mundial no tema nos últimos anos, o desafio que se manifesta de forma preocupante é muito menos de caráter metodológico. O desafio diz respeito muito mais ao sistema político e de exercício de poder, o que desperta questionamentos quanto à capacidade das instituições político-administrativas de incorporar a AAE em processos políticos e de tomada de decisão.

Esses obstáculos são correntes mundialmente e no Brasil não é diferente. $\mathrm{O}$ estudo de caso, no Município de Bueno Brandão, em Minas Gerais, mostrou uma realidade muito distante do que se espera como situação ideal para a aplicação desse instrumento. Isso porque a gestão ambiental no Brasil ainda se dá por meio da solução de problemas isolados e pontuais, e o sistema político carece de ações de planejamento coordenadas e articuladas. Esse fato reafirma o esgotamento de um sistema de planejamento fragmentado e desarticulado.

Além disso, a realidade local mostrou a urgência da necessidade de maior comprometimento político com o trato das questões ambientais em políticas de turismo, de ações de fortalecimento dos mecanismos de participação social, valorização e capacitação do corpo técnico e a produção, sistematização, democratização e monitoramento de informações ambientais, de forma a orientar o planejamento e a tomada de decisão. 
Sem o equacionamento dessas lacunas políticas, institucionais e metodológicas, o Brasil corre o risco de adotar a AAE de forma equivocada, podendo ocasionar situações de descrédito em relação ao instrumento. 


\section{REFERÊNCIAS}

AGRA FILHO, S.S. (2002). Avaliação ambiental estratégica - uma alternativa de incorporação da questão ambiental no processo de desenvolvimento. $247 \mathrm{f}$. Tese (Doutorado) - Instituto de Economia, Universidade Estadual de Campinas, Campinas, 2002.

ANTARCTIC AND SOUTHERN OCEAN COALITION (2000). Antarctic strategic environmental assessment: application to the growing Antarctic tourism industry. Disponível em:<http://www.asoc.org/what_tourism.htm>. Acesso em: 18 jan. 2006.

BANCO DO NORDESTE (2006). Prodetur/NEI - resultados: reduzindo o déficit de infra-estrutura básica no Nordeste. Disponível em:<http://www.bnb.gov.br/content/aplicacao/prodetur/prodetur_ne1/gerados/resulta dos.asp>. Acesso em: 14 set. 2006.

BARBIERI, J.C. (1997). Desenvolvimento e meio ambiente: as estratégias de mudanças da agenda 21. Petrópolis: Vozes.

BELÉM, L. (2006). Leis ambientais são desrespeitadas: no estado da Bahia, a instalação de hotéis e loteamentos vem sendo feita em areas que são protegidas. A Tarde, Salvador. Disponível em: $<$ http://www3.atarde.com.br/cidades/interna.jsp?xsl=noticia.xsl\&xml=NOTICIA/2006/ 03/27/973920.xml>. Acesso em: 5 jan. 2007.

BENI, M.C. (2001). A Política de turismo. In: TRIGO, L.G.G. (Org.). Turismo. como aprender, como ensinar. 2.ed. São Paulo: SENAC. v.1, p.177-202.

. (1991). Análise do desempenho do sistema nacional de turismo instituído na administração pública. 276 f. Tese (Livre-Docência) - Escola de Comunicação e Artes, Universidade de São Paulo, 1991.

BOULLON, R. (2000). Ecoturismo: sistemas naturales y urbanos. 2.ed. Buenos Aires: Librerias y Distribuidora Turísticas.

BOYD, S.W.; BUTLER, R.W. (1996). Managing ecotourism: an opportunity spectrum approach. Tourism Management, London, v.17, n.8, p.557-566, Dec.

BRIGANTE, J.; ESPÍNDOLA, E.L.G. (2003). Limnologia fluvial: um estudo no rio Mogi-Guaçu. São Carlos: Rima.

BROWN, A.L. (2000). SEA experience in development assistance using the environmental overview. In: PARTIDÁRIO, M.R.; CLARK, R. (Ed.). Perspectives on strategic environmental assessment. Boca Raton: Lewis. p.131-139.

BROWN, A.L.; THERIVEL, R. (2000). Principles to guide the development of SEA methodology. Impact Assessment and Project Appraisal, Surrey, v.18, n.3, p.183189, Apr. 
BRÜSEKE, F.J. (1995). O Problema do desenvolvimento sustentável. In: CAVALCANTI, C. (Org.). Desenvolvimento e natureza: estudo para uma sociedade sustentável. São Paulo: Cortez; Recife: Fundação Joaquim Nabuco. p. 29-40.

CARPI JÚNIOR, S. (2001). Processos erosivos, recursos hídricos e riscos ambientais na bacia do rio Mogi-Guaçu. $169 \mathrm{f}$. Tese (Doutorado) - Instituto de Geociências e Ciências Exatas, Universidade Estadual Paulista, Rio Claro, 2001.

CHAKER, A. et al. (2006). A Review of strategic environmental assessment in 12 selected countries. Environmental Impact Assessment Review, New York, v.26, n.1, p.15-56, Jan.

CHAPE, S. et al (2003). 2003 United Nations list of protected areas. Gland: IUCN; Cambridge: UNEP-WCMC.

CHEMONICS INTERNATIONAL (2004). Programmatic environmental assessment Concade: tourism and eco-tourism facilities and activities in the Tropics of Cochabamba. Cairo: USAID.

(2006). Programmatic environmental assessment: Egypt life red sea project. Cairo: USAID.

CIFUENTES, M.A. (1992). Determinación de capacidad de carga turística en áreas protegidas. CATIE. Programa de manejo integrado de recursos naturales. Série técnica. Informe Técnico n. 194. 28 p.

CLARK, R. (2000). Making EIA count in decision-making. In: PARTIDÁRIO, M.R.; CLARK, R. (Ed.). Perspectives on strategic environmental assessment. Boca Raton: Lewis. p.15-27.

COHEN, E. (1978). The Impact of tourism on the physical environment. Annals of Tourism Research, New York, v.5, n.2, p.215-237, Apr./June.

COMISSÃO MUNDIAL SOBRE MEIO AMBIENTE E DESENVOLVIMENTO (1991). Nosso futuro comum. 2.ed. Rio de Janeiro: Fundação Getúlio Vargas.

COMMISSION OF THE EUROPEAN COMMUNITIES (2003). Communication on basic orientations for the sustainability of European tourism: extended impact assessment. Brussels: Comission Staff.

COMITÊ DA BACIA HIDROGRÁFICA DO RIO MOGI GUAÇU (1999). Diagnóstico da bacia hidrográfica do rio Mogi Guaçu: relatório zero. São Paulo: CBH-Mogi; CREUPI.

CONSTANTINE, R.; BRUNTON, D.H.; BAKER, C.S. (2003). Effects of tourism on behavioural ecology of bottlenose dolphins of northeastern New Zealand. Wellington: Department of Conservation. (DOC Science Internal Series, 153). 
DALAL-CLAYTON, B.; SADLER, B. (2005). Strategic environmental assessment: a sourcebook and reference guide to international experience. London: Earthscan.

DAVENPORT, L. et al. (2002). Ferramentas de ecoturismo para parques. In: TERBORGH, J. et al. (Org.). Tornando os parques eficientes: estratégias para a conservação da natureza nos trópicos. Curitiba: Ed.UFPR; Fundação O Boticário. p. 305-333.

DAY, J.C. (2002). Zoning-lessons from the Great Barrier Reef Marine Park. Ocean \& Coastal Management, Barking, v.45, n.2/3, p.139-156.

DENKER, A.F.M. (1998). Métodos e técnicas de pesquisa em turismo. São Paulo: Futura.

DIAS, R. (2003). Planejamento do turismo: política e desenvolvimento do turismo no Brasil. São Paulo: Atlas.

D'IETEREN, E. (2006). Integrer l'environnement dans les processus de developpement touristique: quelle contribution de l'evaluation environnementale strategique a la valorisation touristique des territoires?. In: COLOQUIO INTERNACIONAL DESARROLLO TERRITORIAL Y TURISMO SOSTENIBLE, 2006, Bogotá. Documentos del Coloquio. Bogotá. Universidad Externado de Colombia, 2006.

DUSIK, J.; SADLER, B.; MIKULIC, N. (2001). Developments in strategic environmental assessment in Central and Eastern Europe. In: INTERNATIONAL WORKSHOP ON PUBLIC PARTICIPATION AND HEALTH ASPECTS IN STRATEGIC ENVIRONMENTAL ASSESSMENT, 2000, Szentendre. Anais eletrônicos... Disponível em: <http://www.rec.org/REC/Publications/SEA/SEA_Workshop>. Acesso em: 2 Feb. 2006.

ECON ANALYSIS (2004). A Framework for sustainable tourism development in Honduras: strategic environmental assessment of the tourism strategy. Oslo.

ENVIRONMENTAL RESOURCES MANAGEMENT (2005). Evaluación ambiental estratégica del sector turismo en México. Building.

FREIXÊDAS-VIEIRA, V.M.; PASSOLD, A.J.; MAGRO, T.C. (2000). Impactos do uso público: um guia de campo para utilização do método VIM. In: II CONGRESSO BRASILEIRO DE UNIDADES DE CONSERVAÇÃO, 2000, Campo Grande. Anais. Campo Grande: REDE NACIONAL PRÓ-UUNIDADES DE CONSERVAÇÃO: Fundação O Boticário de proteção à natureza. p. 296-305.

FREY, K. (2000). Políticas públicas: um debate conceitual e reflexões referentes à prática da análise de políticas públicas no Brasil. Planejamento e Políticas Públicas, Brasília, n.21, p.211-259, jun. 
(2001). A Dimensão político-democrática nas teorias de desenvolvimento sustentável e suas implicações para a gestão local. Ambiente e Sociedade, Campinas, n.9, p.1-34, jul./dez.

G.A.PACKMAN \& ASSOCIATES ENVIRONMENTAL CONSULTANTS (2005). Strategic environmental assessment: core area public programming and activities vision. Ontario: National Capital Commission.

GÖSSLING, S. (2000). Tourism - sustainable development option? Environmental Conservation, Cambridge, v.27, n.3, p.223-224, Sept.

GÖSSLING, S. (2001). The consequences of tourism for sustainable water use on a tropical island: Zanzibar, Tanzania. Journal of Environmental Management, vol. 61 , n. 2, p. 179-191, Feb.

GRIGOVA, V.; METODIEVA, J. (2001). Strategic environmental assessment of the Varna municipality development plan. In: INTERNATIONAL WORKSHOP ON PUBLIC PARTICIPATION AND HEALTH ASPECTS IN STRATEGIC ENVIRONMENTAL ASSESSMENT, 2000, Szentendre. Anais eletrônicos... Disponível em:<http://www.rec.org/REC/Publications/SEA/SEA_Workshop>. Acesso em: 2 Feb. 2006.

HANAI, F.Y. (2006). Arquivo particular. Fotografia, color., acervo digital.

HANAI, F.Y.; ESPÍNDOLA, E.L.G.; BRIGANTE, J. (2007). O turismo sustentável como atividade socioeconômica alternativa de desenvolvimento na região da bacia hidrográfica de montante do rio Mogi-Guaçu. In: ESPÍNDOLA, E. L. G.; BRIGANTE, J. Projeto Mogi-Guaçu: desenvolvendo ações sócio-ambientais. São Carlos: Rima, (no prelo).

HEMMINGS, A.; ROURA, R. (2003). A square peg in a round hole: fitting impact assessment under the Antarctic Environmental Protocol to Antarctic Tourism. Impact Assessment and Project Appraisal, Surrey, v.21, n.3, p.13-24, Mar.

HOTÉIS se multiplicam. (2006). Isto é Dinheiro, São Paulo. Disponível em:<http://www.terra.com.br/istoedinheiro/especiais/turismo/hoteis_multiplicam.htm> . Acesso em: 22 out. 2006.

HUNTER, C. (1995). Environmental impact assessment and tourism development. In: HUNTER, C.; GREEN, H. Tourism and the environment: a sustainable relationship? London: Routledge. Cap.5, p.121-168.

(1997). Sustainable tourism as an adaptive paradigm. Annals of tourism research, New York, vol.24, n. 4, p. 850-867, Oct.

INSTITUTO BRASILEIRO DE GEOGRAFIA E ESTATÍSTICA (2006). Disponível em: <http://www.ibge.gov.br/cidadesat>. Acesso em: 13 mar. 2007. 
INSTITUTO DE DESENVOLVIMENTO INTEGRADO DE MINAS GERAIS (2006). Disponível em:<http://www.indi.mg.gov.br/municipios/municipios.asp>. Acesso em: 21 mar. 2006.

INSTUTO MINEIRO DE GESTÃO DAS ÁGUAS (2006). Disponível em:<http://www.igam.mg.gov.br>. Acesso em: 7 abr. 2006.

IRVING, M.A. (2002). Turismo, ética e educação ambiental - novos paradigmas em planejamento. In: IRVING, M.A.; AZEVEDO, J. (Org.). Turismo: o desafio da sustentabilidade. São Paulo: Futura, p. 17-34.

KRIPPENDORF, J. (1989). Sociologia do turismo: para uma nova compreensão do lazer e das viagens. Rio de Janeiro: Civilização Brasileira.

KUO, N.-W. et al. (2005). A Delphi-matrix approach to SEA and its application within tourism sector in Taiwan. Environmental Impact Assessment Review, New York, v.25, n.3, p.259-280, Apr.

LEFF, H. (2002). Epistemologia ambiental. 2.ed. Tradução de Sandra Valenzuela. São Paulo: Cortez.

LEIS, H.R. (1999). Um modelo político-comunicativo para superar o impasse do atual modelo político-técnico de negociação ambiental no Brasil. In: CAVALCANTI, C. (Org.). Meio ambiente, desenvolvimento sustentável e políticas públicas. 2.ed. São Paulo: Cortez, p. 232-247.

LEVETT, R.; MCNALLY, R. (2003). A Strategic environmental assessment of Fiji's tourism development plan. Suva: Worldwide Fund for Nature.

LINDBERG, K.; MCCOOL, S.; STANKEY, G. (1997). Rethinking carrying capacity. Annals of Tourism Research, New York, v.24, n.2, p.461- 465.

MAGRO, T.C. (1999). Impactos do uso público em uma trilha no planalto do Parque Nacional do Itatiaia. $133 \mathrm{f}$. Tese (Doutorado) - Escola de Engenharia de São Carlos, Universidade de São Paulo, São Carlos, 1999.

MARTORANO, F. (2006). Areia de risco. O Eco, Rio de janeiro. Disponível em: $<$ http://arruda.rits.org.br/notitia/servlet/newstorm.ns.presentation.NavigationServlet?p ublicationCode=6\&pageCode=67\&textCode=15566> . Acesso em: $17 \mathrm{dez} .2006$.

MINISTÉRIO DO MEIO AMBIENTE (2002). Avaliação ambiental estratégica. Brasília: MMA/SQA.

. (2006). Disponível em: <http://www.mma.gov.br/port/sqa/aae/index.cfm>. Acesso em: 4 abr. 2006.

MINISTÉRIO DO TURISMO (2003). Plano nacional do turismo: diretrizes, metas e programas. Disponível em: $<$ http://institucional.turismo.gov.br/Mintur/UserFiles/File/planoNacionalPortugues.pd> . Acesso em: 06 mar. 2006. 
(2006).

Disponível

em:

$<\mathrm{http}: / /$ institucional.

turismo.gov.br/mintur/parser/imprensa/noticias/item.cfm?id=ACC8C81B-B8C6-B97FF4C73CB1DC777904>. Acesso em: 14 set. 2006.

MORGAN, R.K.; ONORIO, K.R. (2000). SEA of the Neiafu master plan, VaVa'u, Tonga. In: PARTIDÁRIO, M.R.; CLARK, R. (Ed.). Perspectives on strategic environmental assessment. Boca Raton: Lewis. p.197-213.

MORRIS, P.; THERIVEL, R. (Ed.). (1995). Methods of environmental impact assessment. London: UCL.

NALAMINO, N.; MEYNELL, P.J. (1997). Strategic environmental assessment of development around Victoria Falls, Zambia / Zimbabwe. Parks, Washington, v.7, n 2, p.39-46, June.

NOOTEBOOM, S. (2000). Environmental assessments of strategic decisions and project decisions: interactions and benefits. Environmental Assessment and Project Appraisal, Surrey, v.18, n.2, p.151-160, June.

ORGANIZAÇÃO MUNDIAL DO TURISMO (2003). Turismo internacional: uma perspectiva global. 2.ed. Tradução de Roberto Cataldo Costa. Porto Alegre: Bookman.

. (2005). Tourism highlights: 2006 edition. OMT.

ORTOLANO, L.; SHEPHERD, A. (1995). Environmental impact assessment. In: VANCLAY, F.; BRONSTEIN, D.A. (Ed.). Environmental and Social Impact Assessment. West Sussex: John Wiley. p.3-30.

PARTIDÁRIO, M.R. (1996). Strategic environmental assessment: key issues emerging from recent practice. Environmental Impact Assessment Review, New York, v.16, n.1, p.31-55, Jan.

. (2000). Elements of an SEA framework - improving the added-value of SEA. Environmental Impact Assessment Review, New York, v.20, n.6, p.647-663, Dec.

PARTIDÁRIO, M.R.; CLARK, R. (2000). Perspectives on strategic environmental assessment. Boca Raton: Lewis.

PEREIRA, C.A.S. (1999). Políticas públicas no setor do turismo. Turismo em Análise, São Paulo, v. 10, n. 2, p.7-21, nov.

PIRES, P.S. (2005). "Capacidade de carga" como paradigma de gestão dos impactos da recreação e do turismo em áreas naturais. Turismo em Análise, São Paulo, v.16, n.1, p.5-28.

POWELL, S. et al. (2002). Sucessos e fracassos do complexo de reservas de Monteverde e do sistema nacional de áreas protegidas da Costa Rica. In: TERBORGH, J. et al. (Org.). Tornando os parques eficientes: estratégias para a 
conservação da natureza nos trópicos. Curitiba: Ed. UFPR; Fundação O Boticário. p.181-196.

PREFEITURA MUNICIPAL DE BUENO BRANDÃO (2007). Disponível em: <http://www.buenobrandao.com.br/admin/depart.htm>. Acesso em: 14 fev. 2007.

PROGRAMA DAS NAÇÕES UNIDAS PARA O DESENVOLVIMENTO (2007). Atlas do Desenvolvimento Humano. Disponível em: <http://www.pnud.org.br/atlas/>. Acesso em: 10 jul. 2007.

QUEIROZ, L.A. (2001). A evolução do sistema institucional público do turismo baiano. Bahia Análise \& Dados, Salvador, v. 11, n. 2, p. 20-28, set.

RANIERI, V.E.L. et al. (2005). O Zoneamento ambiental como instrumento de política e gestão ambiental. In: ESPÍNDOLA, E.V.G.; WENDLAND, E. (Org.). PPGSEA: trajetórias e perspectivas de um curso multidisciplinar. São Carlos: RiMa. p.109-136.

RAUSCHMAYERA, F.; RISSEB, N. (2005). A framework for the selection of participatory approaches for SEA. Environmental Impact Assessment Review, New York, vol. 25, n. 6, p. 650-666, Aug.

REPUBLIC OF TURKEY MINISTRY OF ENVIRONMENT AND FORESTRY (2006). Strategic environmental assessment of the Oymapınar Tourism Development Plan: preliminary report. Disponível em:<www.cedgm.gov.tr/scd/ pilotprojectscopingdocument.pdf>. Acesso em: 13 Dec. 2006.

RUSCHMANN, D. (1997). Turismo e planejamento sustentável: a proteção do meio ambiente. Campinas: Papirus.

SACHS, I. (1993). Estratégias de transição para o século XXI: desenvolvimento e meio ambiente. Tradução de Magda Lopes. São Paulo: Studio Nobel: FUNDAP.

(2002). Caminhos para o desenvolvimento sustentável. 2. ed. Rio de Janeiro: Garamond.

SADLER, B. (2001). A framework approach to strategic environmental assessment: aims, principles and elements of good practice. In: INTERNATIONAL WORKSHOP ON PUBLIC PARTICIPATION AND HEALTH ASPECTS IN STRATEGIC ENVIRONMENTAL ASSESSMENT, 2000, Szentendre. Anais eletrônicos... Disponível em: <http://www.rec.org/REC/Publications/SEA/SEA_Workshop>. Acesso em: 2 Feb. 2006.

SALVATI, S.S. (Org.) (2004). Turismo responsável - manual para políticas públicas. Brasília: WWF Brasil.

SÁNCHEZ, L.E. (2006). Avaliação de impacto ambiental: conceitos e métodos. São Paulo: Oficina de textos. 
SANT'ANNA, D.M.; OLIVEIRA, M.T.C.S.; BERENSTEIN, S.G. (2001). Gestão participativa para um turismo sustentável: o caso da Costa do Descobrimento. Bahia Análise \& Dados, Salvador, v.11, n. 2, p.125-130, set.

SERRANO, C.M.T. (1997). A vida e os parques: proteção ambiental, turismo e conflitos de legitimidade em unidades de conservação. In: SERRANO, C. M. T.; BRUHNS, H. T. (Org.). Viagens à natureza: turismo, cultura e ambiente. 5. ed. Campinas: Papirus.

SILVEIRA, C.E.; PAIXÃO, D.L.D.; COBOS, V.J. (2006). Políticas Públicas de Turismo e a Política no Brasil: singularidades e (des)continuidade. Ciência \& Opinião, Curitiba, v.3, n.1, p. 120-135, jan./jun.

SIMÕES, A.F. (2003). O Transporte aéreo brasileiro no contexto de mudanças climáticas globais: emissões de co2 e alternativas de mitigação. $288 \mathrm{f}$. Tese (Doutorado) - Universidade Federal do Rio de Janeiro, Rio de Janeiro, 2003.

SIMPSON, P.; WALL, G. (1999). Consequences of resort development: a comparative study. Tourism Management, London, v.20, n.3, p.283-296, June.

SMUTNY, M. et al. (2005). SEA of development concepts in the Czech Republic. In: SADLER, B. (Ed.). Strategic environmental assessment at the policy level: recent progress, current status and future prospects. Disponível em:<http://www.iaia.org>. Acesso em: 2 Feb. 2006.

SOUZA, M.P. (2000). Instrumentos de gestão ambiental: fundamentos e prática. São Carlos: Riani Costa.

SRIKOSAMATARA, S.; BROCKELMAN, W.Y. (2002). Conservação em áreas protegidas da Tailândia: uma diversidade de problemas, uma diversidade de soluções. In: TERBORGH, J.; VAN SCHAK, C.; DAVENPORT, L. (Org.). Tornando os parques eficientes: estratégias para a conservação da natureza nos trópicos. Curitiba: Ed.UFPR; Fundação O Boticário. p.241-254.

SWARBROOKE, J. (2000). Turismo sustentável: conceitos e impacto ambiental, vol. 1. Tradução de Margarete Dias Pulido. São Paulo: Aleph.

THERIVEL, R. (1998). Strategic environmental assessment of development plans in Great Britain. Environmental Impact Assessment Review, New York, v.18, n.1, p.39-57, Jan.

Earthscan.

(2004). Strategic environmental assessment in action. London:

THERIVEL, R.; PARTIDÁRIO, M.R. (1996). The Practice of strategic environmental assessment. London: Earthscan.

THERIVEL, R.; WALSH, F. (2006). The strategic environmental assessment directive in the UK: 1 year onwards. Environmental Impact Assessment Review, New York, vol. 26, n. 7, p. 663-675, Oct. 
THERIVEL, R. et al. (1992). Strategic environmental assessment. London: Earthscan.

TICHÁ, M. et al. (2004). Assessment of environmental impacts of the proposed sectoral operational programme for tourism and the spa industry. In: STRATEGIC ENVIRONMENTAL ASSESSMENT, MAKING A DIFFERENCE. EEB Seminar, 2003, Brussels. Anais eletrônicos... Disponível em: <http://www.eeb.org/publication/general.htm>. Acesso em 10 Feb. 2006.

UNITED NATIONS DEVELOPMENT PROGRAMME (2005). Strategic environmental assessment of the 2006-2010 national tourism development programme of the Republic of Belarus. Minsk.

UNIVERSIDADE FEDERAL DO RIO DE JANEIRO. Coordenção dos Programas de Pós-Graduação de engenharia. Laboratório Interdisciplinar do Meio Ambiente (2006). Disponível em: <http://www.lima.coppe.ufrj.br/iexplorer/index.htm>. Acesso em: 4 abr. 2006.

WARD, M. et al. (2005). SEA experience and opportunities in New Zealand. In: SADLER, B. (Ed.). Strategic environmental assessment at the policy level: recent progress, current status and future prospects. Disponível em: <http://www.iaia.org>. Acesso em: 2 Feb. 2006.

WEARING, S.; NEIL, J. (2001). Ecoturismo: impactos, potencialidades e possibilidades. Barueri: Manole.

WILBURN, G. (2005). SEA experience at the federal level in Canada. In: SADLER, B. (Ed.). Strategic environmental assessment at the policy level: recent progress, current status and future prospects. Disponível em: <http://www.iaia.org>. Acesso em: 2 Feb. 2006. 